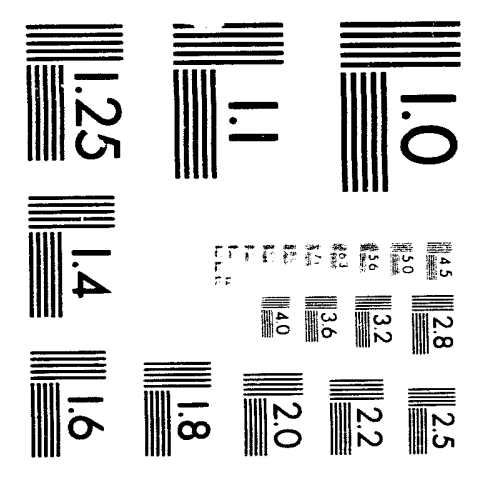



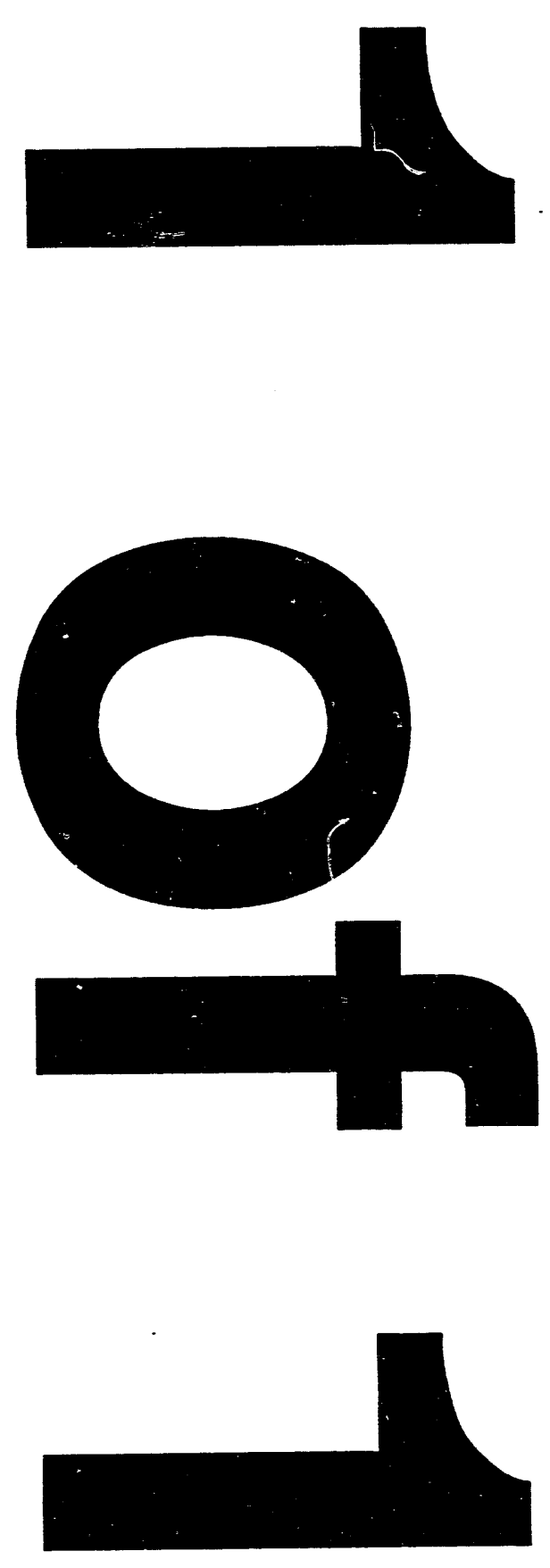
SAND92-2284

Unlimited Release

September 1993
Distribution

Category UC-126

\title{
Strategic Petroleum Reserve (SPR) \\ Additional Geologic Site Characterization Studies \\ Bayou Choctaw Salt Dome, Louisiana
}

\author{
James T. Neal \\ Sandia National Laboratories \\ Albuquerque, New Mexico \\ Thomas R. Magorian \\ Amherst, New York
Kathleen O. Byrne and Steven Denzler
Acres International Corporation
Amherst, New York

Prepared by Sandia National Laboratories

Albuquerque, NM 87185 and Livermore, CA 94550

for the U.S. DOE under Contract DE-ACO4-76DP00789 


\begin{abstract}
This report revises and updates the geologic site characterization report that was published in 1980. Some of the topics covered in the earlier report were provisional and it is now possible to reexamine them some 13 years later, using the data obtained from SPR cavern operations and several new caverns, and the experience of the Union Texas Petroleum Company, the operator of nine caverns adjacent to the DOE property.

Revised structure maps and sections show interpretative differences in the dome shape and caprock structural contours, especially a major east-west trending shear zone, not mapped in the 1980 report. Excessive gas influx in Caverns 18 and 20 may be associated with this shear zone.

Subsidence values at Bayou Choctaw are among the lowest in the SPR system, averaging only about $10 \mathrm{~mm} / \mathrm{yr}(0.4 \mathrm{in} / \mathrm{yr})$, but measurement and interpretation issues persist, as observed values often approximate measurement accuracy. Periodic, temporary flooding is a continuing concern because of the low site elevation (less than $10 \mathrm{ft}$ ), and this may intensify as future subsidence lowers the surface even further.

Cavern 4 was re-sonared in 1992 and the profiles suggest that significant change has not occurred since 1980, thereby reducing the uncertainty of possible overburden collapse -- as occurred at Cavern 7 in 1954. Caprock integrity may be affected by structural features, such as the east-west trending fault system that essentially divides the dome into northern and southern lobes. Other potential integrity issues persist, such as the proximity of Cavern 20 to the dome edge, and the narrow web separating Caverns 15 and 17. The Cavern 20 web is now believed to be some $90 \mathrm{ft}$ thicker, as a result of well deviation that had not been considered earlier.

Injection wells have been used for the disposal of brine but have been only marginally effective thus far; recompletions into more permeable lower Pleistocene gravels may be a practical way of increasing injection capacity and brinefield efficiency. Cavern storage space is limited on this already crowded dome, but $15 \mathrm{MMBBL}$ could be gained by enlarging Cavern 19 and by constructing a new cavern beneath and slightly north of abandoned Cavern 13. Environmental issues center on the low site elevation: the backswamp environment combined with the potential for periodic flooding create conditions that will require continuing surveillance.
\end{abstract}




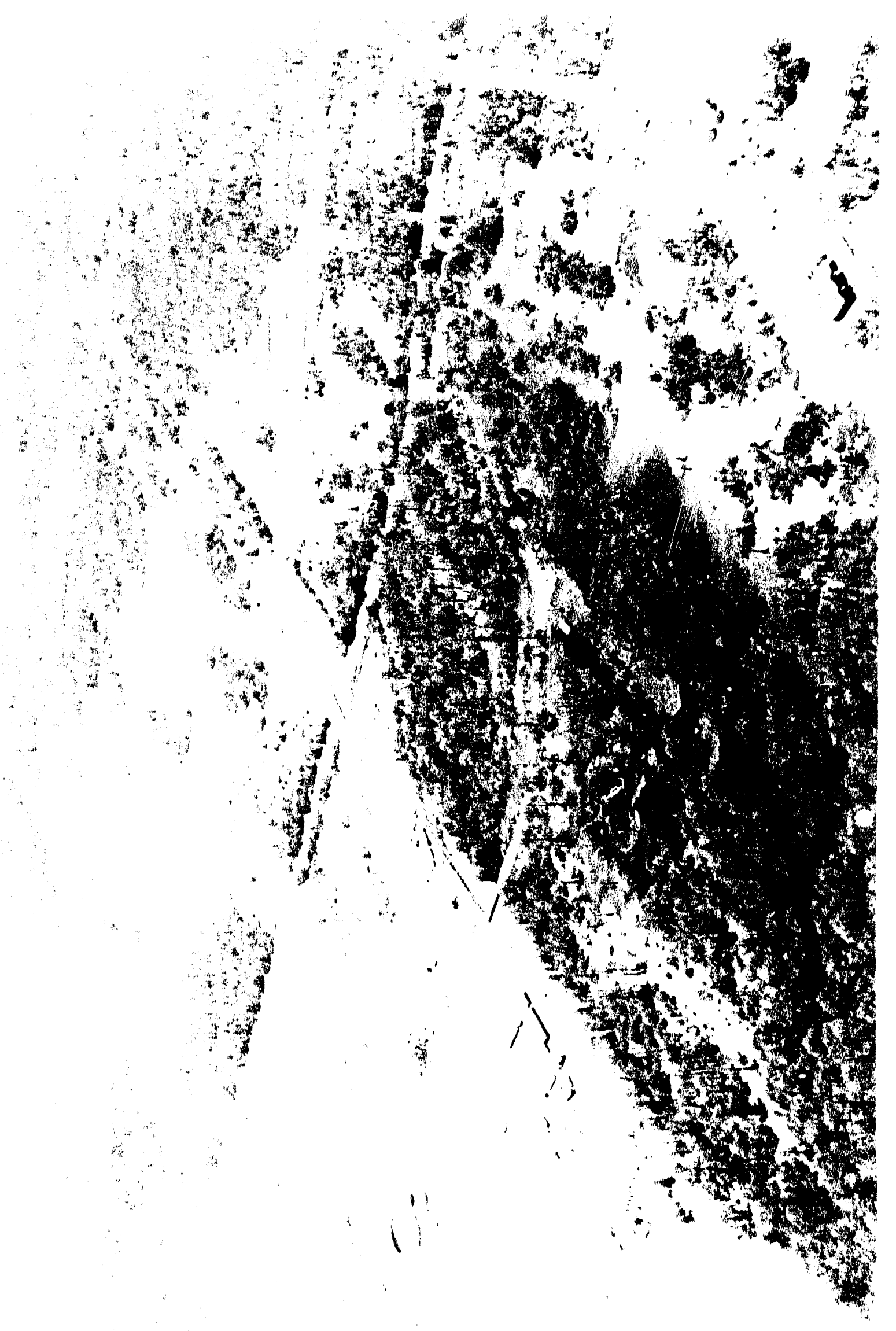




\section{TABLE OF CONTENTS}

\section{Strategic Petroleum Reserve (SPR) Additional Geologic Site Characterization Studies \\ Bayou Choctaw Salt Dome, Louisiana}

EXECUTIVE SUMMARY ....................................................................................

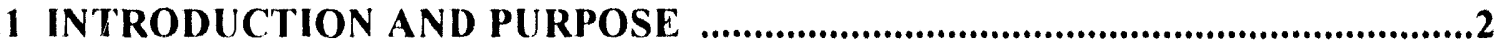

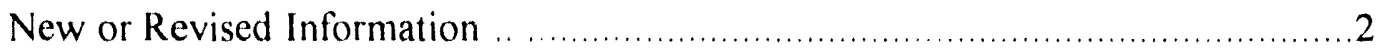

2 GEOLOGIC ASPECTS .................................................................................... 3

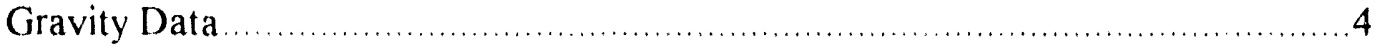

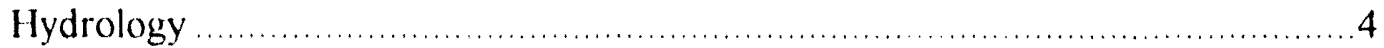

Injection Wells for Brine Disposal _.............................................. 9

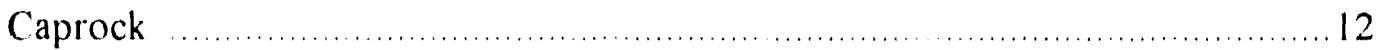

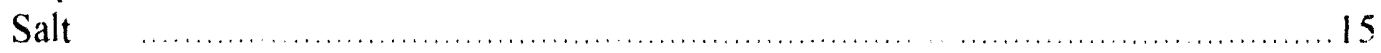

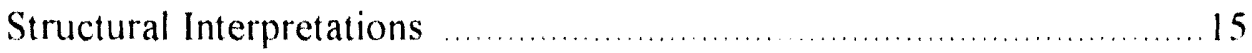

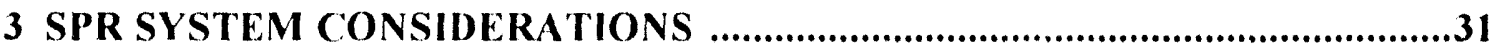

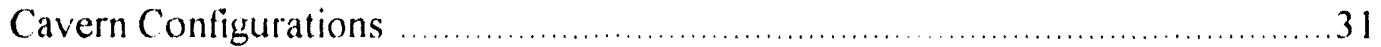

SPR Caverns ….................................................................... 31

Union Texas Petroleum Caverns ..................................................34

Cavern Integrity Issues .............................................................. 35

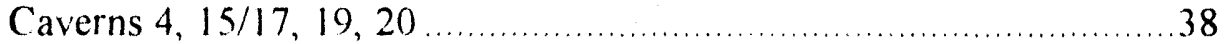

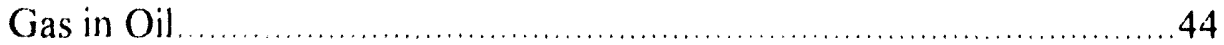

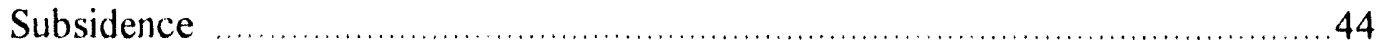

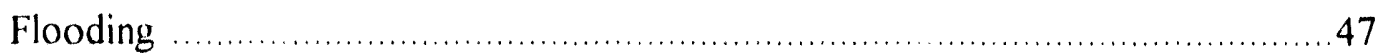

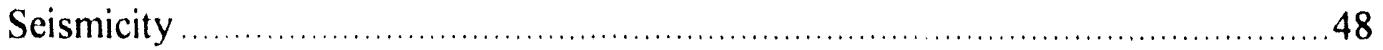

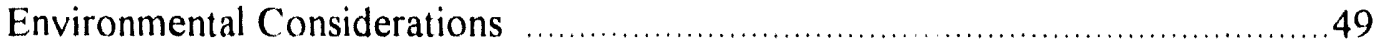

Expansion Possibilities ............................................................................ 49

4 SUMMARY OF SIGNIFICANT FEATURES AFFECTING SPR …..................51

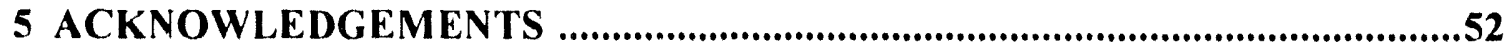

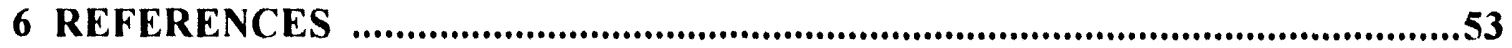

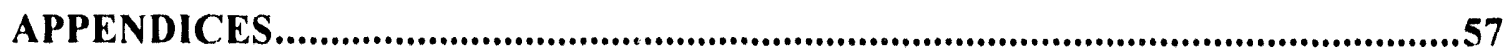

A -- Bayou Choctaw Regional Geologic History .................................... A-1

B -- Bayou Choctaw Well Data …….......................................................

C -- Cavern 4 Sonar Analysis and Comparative Evaluation ..............................

D -- Cavern 101 Shape: Experimental Graphical Representation …................. D-1 


\section{LIST OF FIGURES}

Frontispiece Bayou Choctaw during flooding, 13 April 81 .............................iii-iv

1 Well Locations and Cross Section Index .................................................. 5-6

2 Residual Gravity Values over Bayou Choctaw Salt Dome ............................... 7-8

3 Contours, Top of Margimulina texana Sand .......................................... 10

4 Contours, Top of Heterostegina Reef ....................................................... 11

5 Contours, Top of Caprock ............................................................ 13-14

$\mathbf{6 a}$ Isometric view of salt stock configuration ............................................. 16

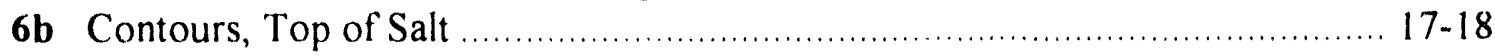

7 Cross Section 1, East-West, Through Caverns 10, 4, \& $18 \ldots \ldots \ldots \ldots \ldots \ldots \ldots \ldots . . \ldots 21-22$

8 Cross Section 2, North-South, Through Caverns 119, 8a, 1, 2, 3, 4, \& 7 (Cavern Lake)

9 Cross Section 3, Southwest-Northeast, Through Caverns 20, $8 \mathrm{a}, 4,15, \& 17$

10 Cross Section 4, Northwest-Southeast, Through Caverns 11, $1,16,25$

11 Cross Section 5, North-northwest/South-southeast, Through

Caverns (D), 13, 11, 102, 1, 101, 8a, \& 19................................. 29-30

12 Strategic Petroleum Reserve Caverns .............................................. 33

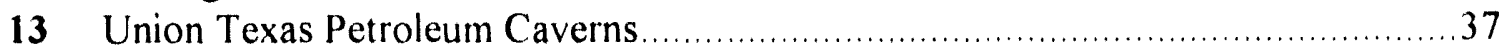

14 Sonar Profiles of Cavern 4 (from 1980 Characterization Report) ..........................39

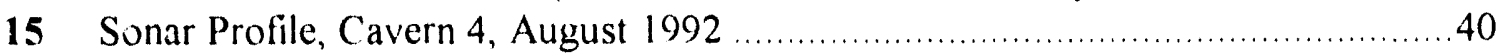

16 Cross Section Through Cavern 20 and Edge of Salt .....................................43

\section{LIST OF TABLES}

1 Stratigraphic Nomenclature and Geologic Column .......................................20

2 Geotechnical Data; Strategic Petroleum Reserve Caverns ................................... 32

3 Geotechnical Data; Union Texas Petroleum Caverns ....................................... 36

4 Elevation Change at Selected Subsidence Stations: 1982-1993 ........................ 46 


\section{EXECUTIVE SUMMARY}

This update of the 1980 geological site characterization of the Bayou Choctaw SPR facility is largely a refinement of the earlier report. However, it also substantiates many previous conclusions significant to safe cavern storage, and adds new insight on several important features that affect cavern operations.

The regional geological setting of th. Bayou Choctaw dome is quite well known as a result of widespread petroleum extraction. The structure contours of the salt stock are simplified to a degree, eliminating several smaller faults that have minimal bearing on cavern storage operations. The contour maps of the caprock and salt surfaces are modified and show a major shear zone transecting the dome. This anomalous feature probably has caused the preferential leaching and elongation of several caverns, and may also be associated with excess gas accumulation in Caverns 18 and 20

Cavern 4 stability has been the object of continuing concern because of its geologic similarity to collapsed Cavern 7 (now Cavern Lake). 1992 sonar results show minimal change since 1980, suggesting that significant caprock dissolution has not occurred and that overburden collapse is unlikely. However, continuing surveillance is prudent.

Caverns 15 and 17 should continue to be operated at essentially equal pressure as the 10() $\mathrm{ft}$ web thickness between them is pressure sensitive. Drawdown of these caverns will reduce the web thickness, leading to eventual coalescence and development of a single cavern

Cavern 20 is $225+50 \mathrm{ft}$ from the edge of the salt stock, $90 \mathrm{ft}$ farther than originally thought Previous determinations had not considered the cavern well deviation. The location near the edge of the salt limits oil drawdown to one or two cycles, but limited volumes may be extracted from the upper cavern segments above 4000 ot without extending the current maximum radius.

Co-use of this dome with Union Texas Petroleum has proceeded with good cooperation and communication, even involving exchange of storage space to satisfy individual needs, and the transfer of brine for petrochemical processing. Total cavern space of the two operators is some $160 \mathrm{MMB}$, in 15 active and 10 abandoned caverns. This volume is sufficient to produce a small amount of subsidence (averaging $005 \mathrm{ft}$ per year) as a result of the continuing process of salt creep closure.

Periodic, temporary flooding is a fact of life around the dome, because of the low elevation under 10 ft and the ever-present cyclonic storms carrying high moisture This pattern will not change and the continuing subsidence may require future road enhancement

Seismicity is not a threat, but minor earthquakes can be expected to recur. The 1983 temblor (Richter Magnitude 3.8) with epicenter 17 miles from West Hackberry exemplifies the type of small seismic events that occur along Gulf Coast growth faults, usually with local, minor effects.

Expansion space on the already crowded and small Bayou Choctaw dome is extremely limited and $25 \mathrm{MMB}$ of new space may be the upper limit for both operators. New caverns near salt stock edges are much more risky than interior locations, the latter being essentially fully occupied.

Injection wells are the principal means of brine disposal and have been less successful than originally planned. Current practices offer new hope for improved performance, and recompletion of existing wells at more shallow depths is possible. The older practice of using screened completions is largely obsolete, and careful attention to preventing flowback of brine is necessary to prevent sand influx in the wells 


\section{INTRODUCTION AND PURPOSE}

The initial geological characterization of the Bayou Choctaw salt dome was conducted in 1979-80 [Hogan et al., 1980]. Although the basic elements are essentially unchanged, refinements to the original report are now possible because of new information gained since then, and because of some 13 years operating history by SPR, and more than 50 years by Union Texas Petroleum (UTP) and its predecessors.

Caprock conditions have been a continuing concern because of its thinness and leachthrough potential. Such conditions led to the overburden collapse over Cavern 7 in 1954 and the consequent formation of Cavern Lake. A similar situation exists with abandoned Cavern 4, which has the potential for a similar sinkhole collapse; thus periodic appraisals of Cavern 4 caprock conditions are desirable.

Salt contours need to be modified somewhat, as several new wells suggest complexities may occur in the overhang geometry. The resulting structural interpretation is modified from that in the 1980 report; the refinements reveal nuances that had not been recognized previously. The earlier report was prepared using manual graphics; modern methods rely on computer software which yields improved contour smoothing and interpretation. New understanding of salt tectonics in the Gulf of Mexico basin has altered traditional concepts, but this probably has little effect relative to Bayou Choctaw.

A number of caverns have been enlarged and some new ones leached. Oil has been filled in the SPR caverns, and the wells of older, unusable caverns have been plugged and abandoned. UTP has modified its operation somewhat, and plans call for the conversion of two caverns for storage of natural gas; one conversion was completed in 1992. The implications of these changes are synthesized, and appropriate revisions documented.

The generally low elevation (under $\sim 10 \mathrm{ft}$ ) makes periodic flooding a continuing concern, and subsidence resulting from cavern creep closure an ongoing issue. Some ten years of survey data are evaluated, with a view toward forecasting future trends.

Finally, several environmental conditions are considered. Co-use of this site by two operators requires continuing close coordination.

\section{New or Revised Information}

Since the 1980 report was published, SPR Caverns 18, 19, \& 20 have been enlarged substantially; UTP Caverns 6 and 26 have been constructed, and Caverns 101 and 102 were leached by DOE. Cavern 102 subsequently was traded to UTP in a swap for Cavern 17, now used for SPR oil storage. In 1992 UTP converted its brine Cavern 24 to natural gas storage and by year's end had a billion cubic feet in storage. UTP had plans in 1993 for a new cavern south of Cavern 26 along the northeast dome edge. 
New data from the nearby oil and gas wells is sparse as the Choctaw field was already a mature producer prior to the advent of SPR oil storage. However, some refinements are possible, based on new wells or new logs; consequently our revised understanding is presented. Of some particular interest to cavern stability considerations is the revised fault map that shows a lateral shear transecting the entire doine in an east-west direction, marking an anomalous zone.

Injection wells have been the primary method of brine disposal at Bayou Choctaw (along with limited transfers for petrochemical use), and there is now ample history to discuss methodology in hindsight (Changes in procedures and well recompletions at shallower depths are suggested, based on experience here and on data from other wellfields

Subsidence data on the DOE property has been accuired nearly annually since 1982, and show some indications of subsidence trends, verifying the very low values that were obtained from earlier UTP data.

Flooding potential was re-examined and modified, based on revised flood insurance rate maps [FEMA] and Corps of Engineers experience

Cavern 4, potentially unstable and geologically similar to collapsed (1954) Cavern 7, was re-sonared in August 1992. The results showed a profile similar to that obtained in 1980, indicating that the caprock probably has not eroded much further, although some uncertainty still exists. Consequently, a repeat of the Cavern 7 collapse seems an unlikely probability at this time.

\section{GEOLOGIC ASPECTS}

The regional geology that was presented in the 1980 report is essentially unchanged; consequently few remarks are necessary. A summary of the regional geologic history is included at Appendix A.

However, significant refinements have been made to the detailed geology of the Bayou Choctaw dome, and new structural contour maps were constructed for top of caprock, salt, the Heterostegina reef, and the Margimulina texama sand. Some 300 wells were available to use in constructing the contour maps and cross sections; these are shown on Figure I (well location), and listed in Appendix B, along with stratigraphic marker horizons, also listed here in Table 1 , p. 20.

The intricate pattern of small faults in sediments described and mapped in the original 1980 characterization report cannot be found within the salt or caprock, nor in the sediments more than a few hundred feet away from the salt stock. They rarely cut more than a few sands even in contact with the salt stock. In the interest of clarity, they have been omitted from the maps and sections in this report, as there is virtually no effect on cavern storage integrity. As a result, only three faults cutting the caprock and salt are included on the revised maps and discussed here. The major east-west fault is probably active, as suggested in the present subsidence data, although its 
topographic expression is subtle. It probably separates two spines within the salt and can be considered an anomalous zone, or shear zone [Neal et al., 1993]. The two additional and less certain faults form a shear pattern over the western crest and overhang.

\section{Gravity Data}

Residual gravity contours are plotted on Figure 2 for the area immediately adjacent to the dome; the gravimeter readings were taken at approximate quarter-mile spacing, or occasionally less along roads. The gravity data show a 22 milligal negative anomaly over the salt stock, typical of a dome of this size. St. Gabriel, the next dome to the east is only a 10 milligal negative feature, typical of a cone of salt at $11,000 \mathrm{ft}$. At Bayou Choctaw the thin caprock is reflected in the minimal 7 milligal positive anomaly over the site, resulting in a net -15 milligals Its nose extends westward over Cavern 20, along the main fault, possibly related to a salt ridge toward Bayou Blue, the next dome to the west, and also reflected in the high temperature found in Texaco \#1 well at the west edge of the map. More gravimeter stations were used to detail this feature [PGA and Associates, 1978]. The similar extension northeastward over UTP Cavern 26 supports the existence of more salt at the edge of the dome than was predicted by one consultant. The anomalous zone that transects the dome is clearly defined as a sharp step on the top of the salt and caprock, as llapped in this report. The Mississippi River levee east of the site is a broad positive anomaly c 6 milligals, showing that gravity data can be related to hydrology and shallow stratigraphy, including subsidence as well as growth-fault structure

\section{Deeper Structure}

The contour map of top of the Margimulina kexama sands (Figure 3) shows general similarity to previous maps, but with much less detail, so as to simplify the interpretation.

The contour map of the top of the Heterosteginu reef (Figure 4) is far less complex than was presented in the 1980 report, showing the principal structure in the E-W fault that transects the dome. The previously identified faults are not shown, as they are very localized and presumably have no effect on cavern storage

\section{Hydrology}

Few, if any, changes requiring modification have occurred since the original characterization. The base of fresh water (as defined by the U. S. Geological Survey 20-ohm criteria) is at $500 \mathrm{ft}$ over the dome. The base of the same Gonzales Aquifer lies directly on the caprock, below which all aquifers are saline, as previously described. Water that will actually meet drinking water standards is found only above a depth of $400 \mathrm{ft}$.

A special study of the hydrocarbon accumulations in the shallow sands over the caprock was done in 1984-85, when a private company's assignees were offered the opportunity to develop these resources which they were claiming. Although ethane which had escaped from Cavern 4 was found in coreholes, only a small amount of natural gas was ever detected away from the older shallow and leaky caverns. Their claims for possible oil were based on the resistivity of 


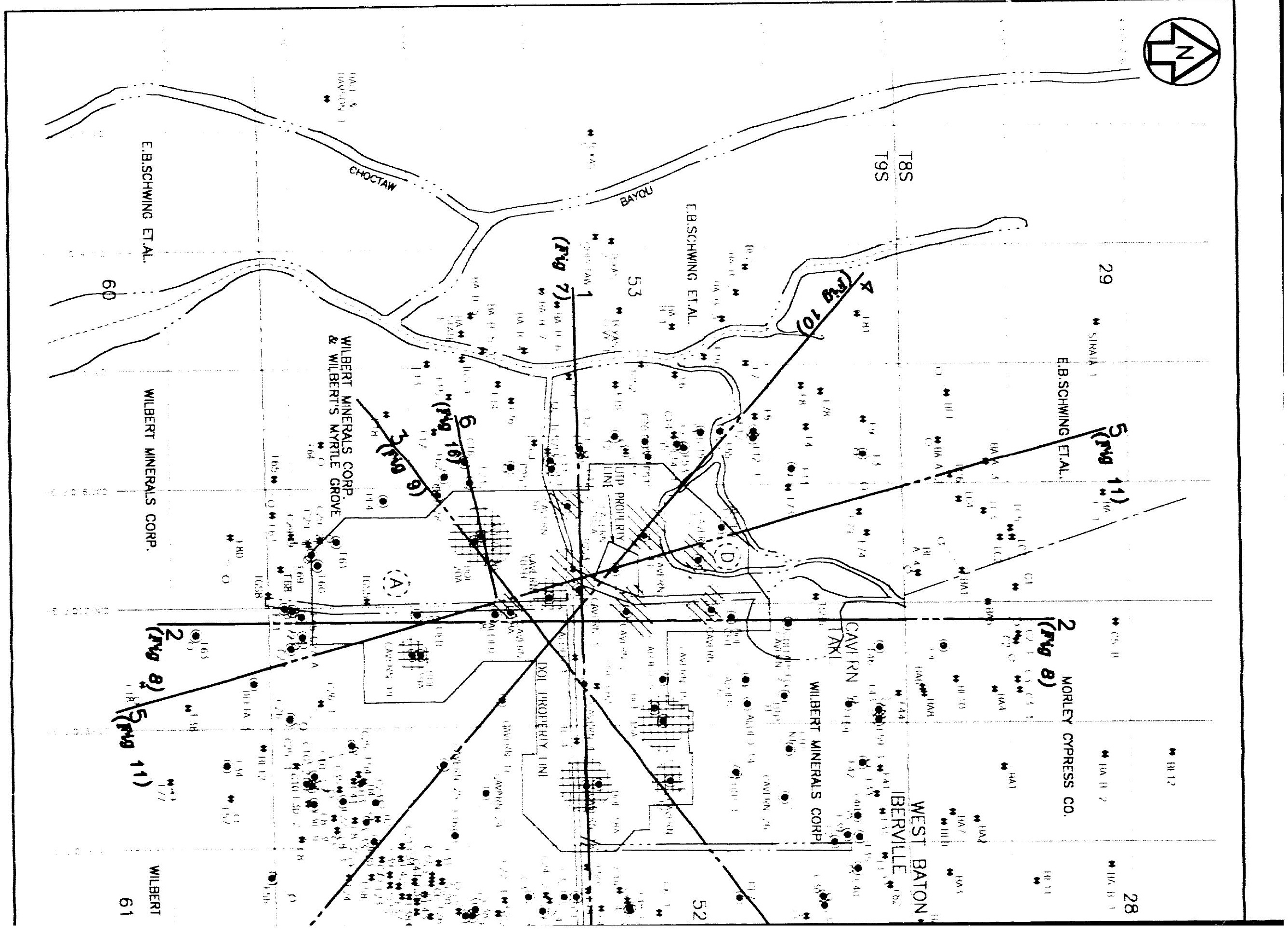




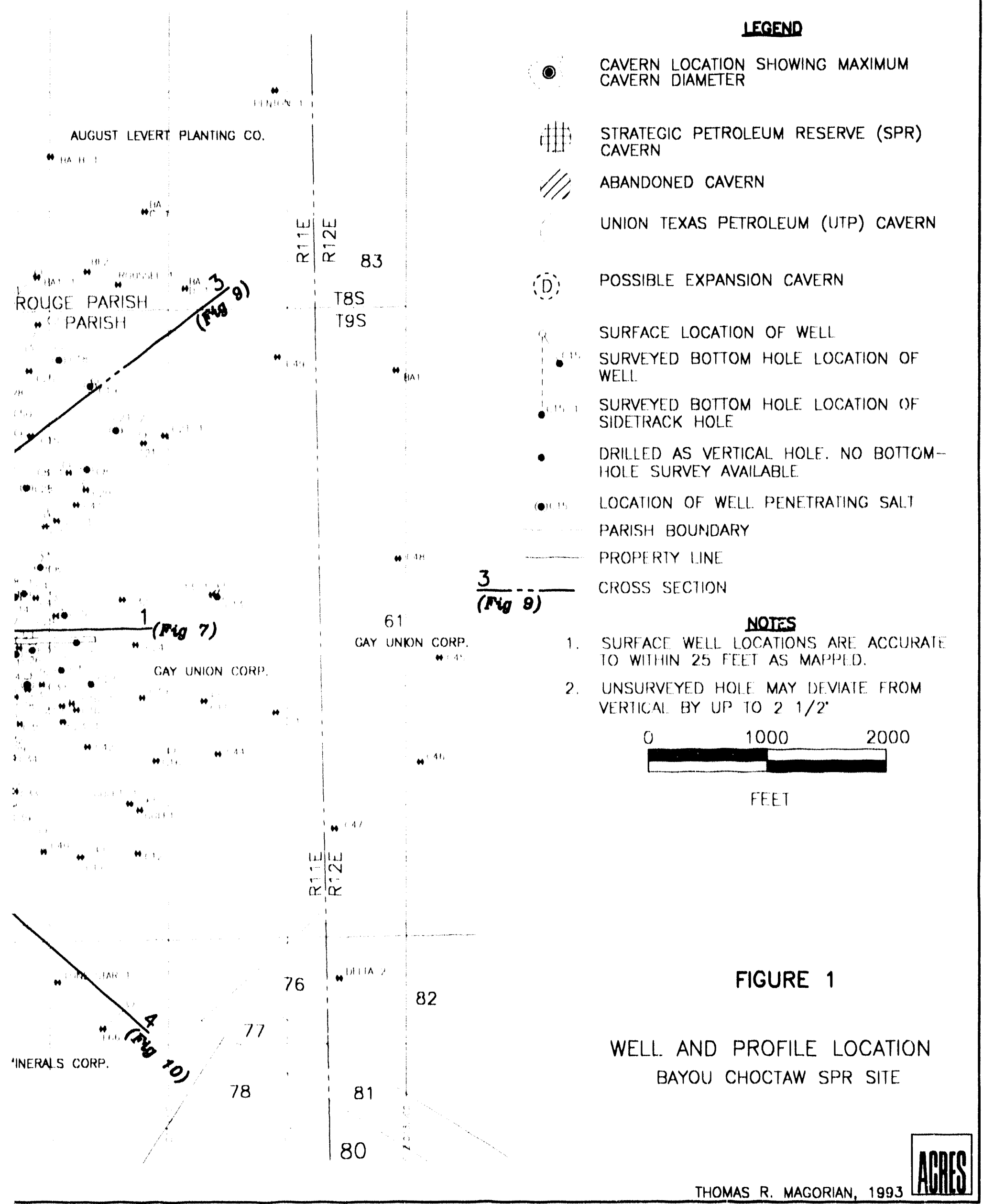




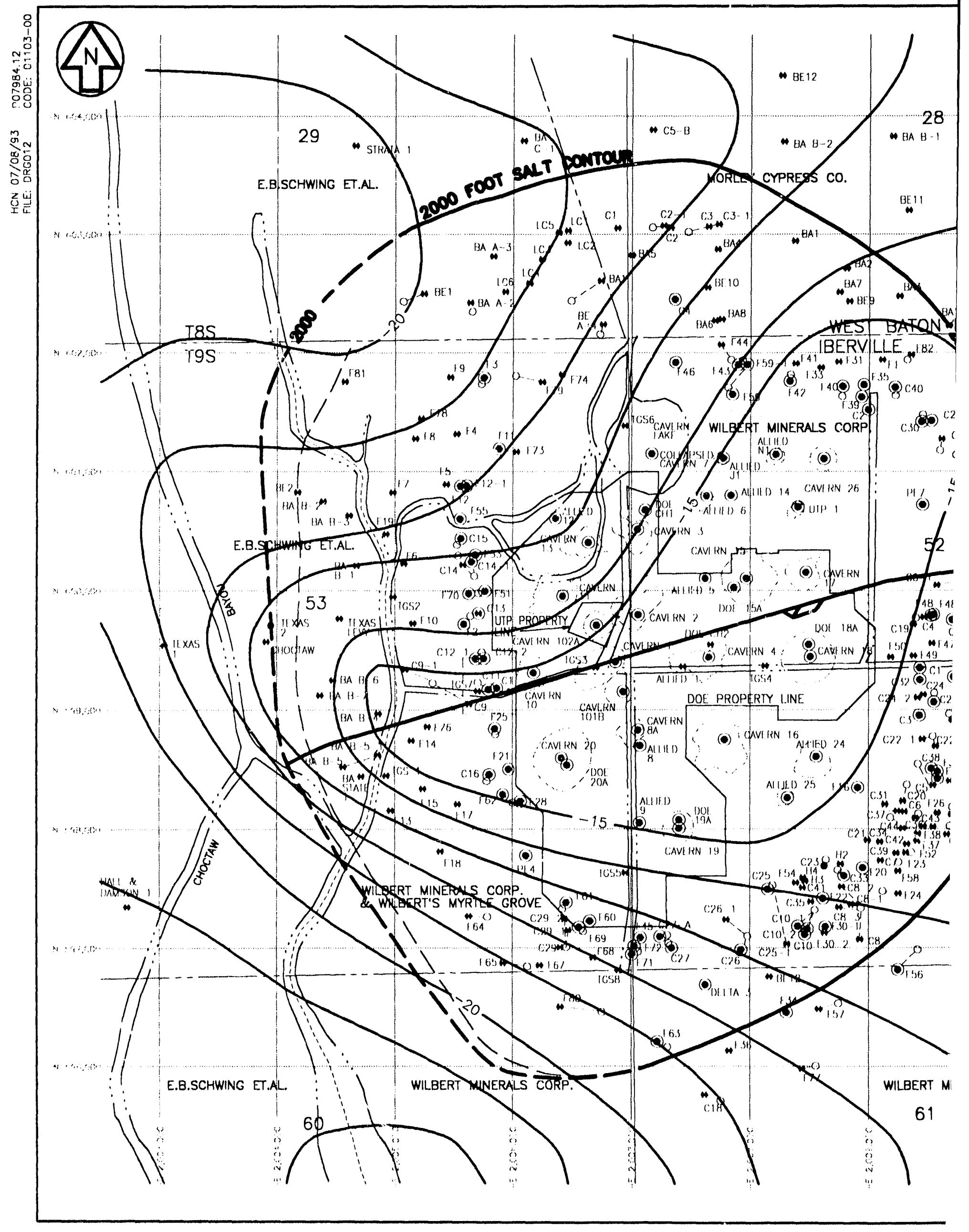




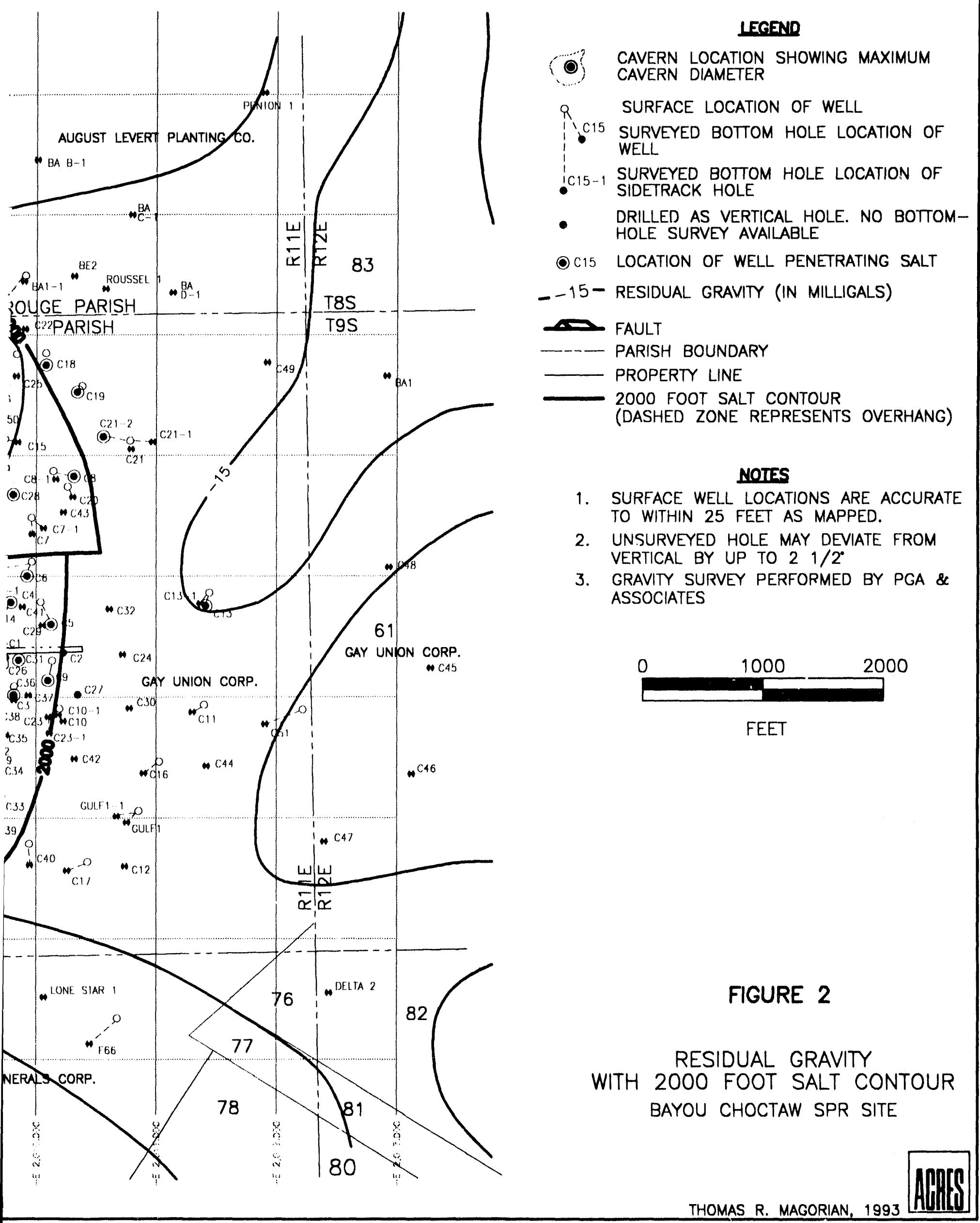


the fresh-water sands, as shown on the logs in the original characterization report, and they were never able to raise the money to test them. This spurious sort of possible economic prospect has occurred on many salt domes and is easiest to dismiss simply by allowing closely-monitored test drilling only to the top of the salt.

\section{Injection Wells}

The Bayou Choctaw disposal wellfield was constructed in 1978 using concepts and completion techniques that are somewhat different than being practiced in 1993 . The 12 wells have not performed as originally intended for a variety of reasons, some of which are because of inherent limitations in formation properties, and some of which are due to the completion techniques that were used. All 12 have been recompleted -. \#s 6 and 12 in 1984, and the remainder in 1987, but repeating the same procedures higher in the geologic sections, and thus with similar and less than desired results. Eleven wells are currently capable of receiving about 100,000 BPD; No. 12 was removed from service because of downhole mechanical problems, presumably screen clogging, as its average yield was just 5400 BPD over 637 days of operation. The original completion was screened open hole below the casing shoe, but was later plugged and then recompleted in 1984 with perforations in two separate 30 -foot zones near 6500 feet. An epoxy-coated sand was "squeezed" into the reservoir, ostensibly to prevent fallback into the well casing. Such practices, while popular 15 years ago, are seldom used today.

The remaining 11 wells are using several Miocene sands between 4000 and 5000 feet, particularly Sand 2 at 4500 feet. The wells have been screened twice now in several of the candidate Miocene sands and the screens have irreversibly clogged while operated without adequate filtration. Screen completions are much too dependent on the filtration system, including expensive cartridge polishing filters at each well, since the screens cannot be effectively cleaned once installed. The state-of-the-art technology now avoids screens and includes more cost-effective cyclone (centrifugal separator) filtration, along with alum treatment in the brine pond. Little disposal has been achieved below Sand 2 (Upper Miocene Bigenerina $B$ zone because this sand and the \#I sand immediately above it will take all the brine available. Recompletions with open perforations are now preferred, based on accumulated industry-wide experience. As long a rathole as possible is kept open to reduce the frequency of sanding up the disposal face.

Because brine disposal through well injection will continue to be a major operating requirement in coming years, some attention can now be given to recompleting the wells at even shallower depths and using newer methods, with appropriate filtration and at much lower cost. While the current system has been baselined to dispose of 100,000 BPD, the formations are capable of accepting several times this amount, as has been demonstrated in other operations at other sites. The PB-KBB [1989] study of the brine disposal system showed that sufficient thick sands exist to handle the brine with negligible pressure buildup in the formation behind the screens, and that no faulting occurs in or near the brine field.

Since the Illinoian and Wisconsinan sands (Gonzales Aquifer) lie above the caprock, they are relatively fresh. The shallowest beds of interest for brine injection are the basal Pleistocene 


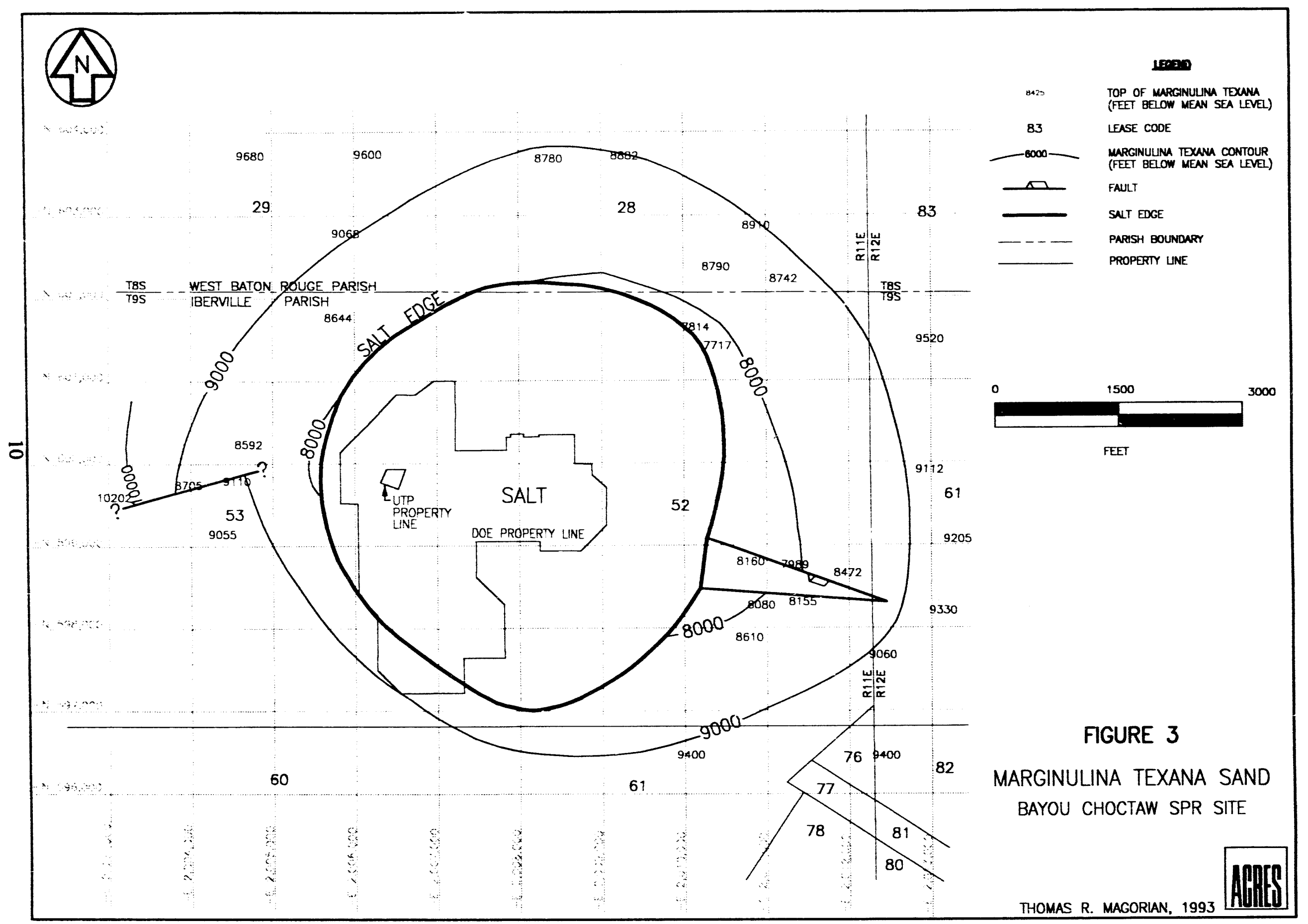




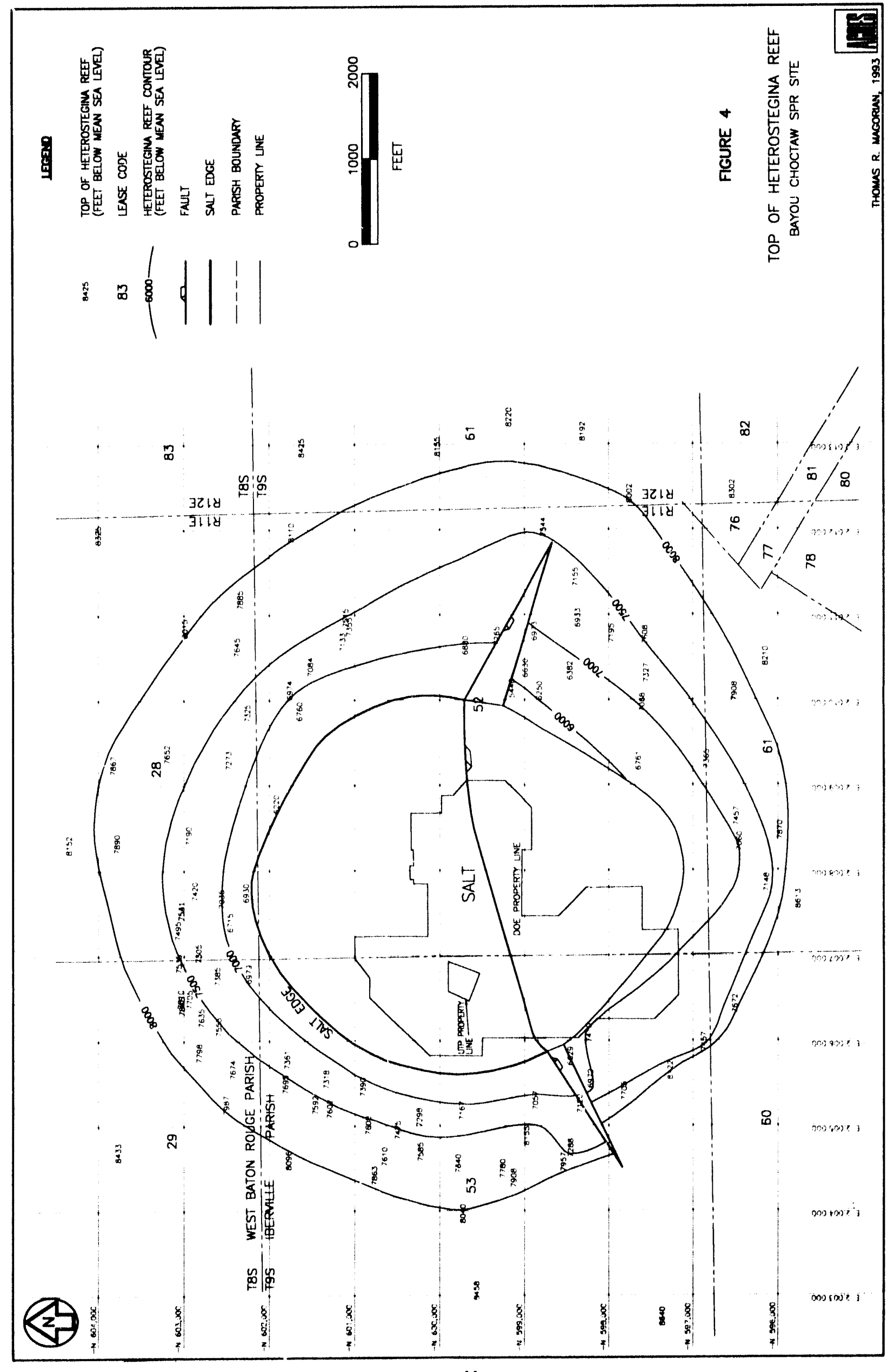


"Lafayette" (Citronelle Fm.) gravels occurring below 900 feet on the flanks of the dome and 1250 feet in the brine injection area. The 100 feet of gravel is separated from the Gonzales by two clays each over 100 feet thick, the lower of which is more than 200 feet thick in the brine injection field. The intervening Kansan sand is 30 feet thick near the dome, and 100 feet thick and fully saturated with brine in the disposal area

Several 100 to 200-foot sands are found between the "Lafayette" gravel and the (\#1) sand presently used for brine injection at a depth of 4000 feet, particularly the Goliad at the base of the Pliocene and the A sand. These might be used in addition to the Lafayette gravels.

\section{Caprock}

The revised caprock map (Fig. 5) shows much more detail in the topography atop the caprock, especially where shallower than $600 \mathrm{ft}$, which was the limit shown in the earlier report. The "high" shown in the southwest corner suggests the presence of a dominant lobe or salt spine, emergent in that vicinity. Improved well control along the eastern flanks allows the revised map to extend the contours another $1000 \mathrm{ft}$ eastward, to a depth of $5000 \mathrm{ft}$. A major fault, dipping to the southeast, exhibits minor displacement on the caprock surface. This fault is active and marks the boundary anomalous zone in the dome. Other faulting that is shown on the cross-sections (Figs. 7-11) comes through the caprock to the surface and is uncertain and probably minimal, in the sense that caprock is inevitably extensively faulted because of the continued movement of the underlying sait

The major fault transecting the dome, oriented $\mathrm{N} 75^{\circ} \mathrm{E}$, appears to have affected the shape of some of the now-abandoned caverns, particularly Cavern 4. This azimuth may also reflect the direction of secondary faulting and jointing in the caprock.

The 1980 characterization report indicated some disagreement between authors on the amount of anhydrite and carbonate in the caprock. X-ray diffraction analyses in 1978 of selected samples reported only gypsum in the sulfate components, and this may be important from a solubility and structural integrity viewpoint as gypsum is some: vhat less soluble than anhydrite at temperatures less than $50^{\circ} \mathrm{C}$. Conceivably this could lead to less solutioning in the alreadyeroded caprock over Cavern 4. Corehole 2 over Cavern 4 provided some of those samples for $\mathrm{x}$-ray determination that showed only gypsum. There has not been any new information that would resolve this disagreement and the 1992 sonar survey of Cavern 4 showed litlle change from the previous 1980 survey, although a $6 \%$ volume increase may be equivocable, owing to inherent accuracy limitations in sonar surveys. This suggests that the caprock over the cavern is only questionably stable at this time, but at least that major changes did not occur. The absence of carbonate caprock has prevented development of the lost-circulation zones or karst which has plagued cavern development in many other domes.

Slezak (1988) indicated that previous brine injection into caprock had induced caprock shifting and that this practice was possibly associated with casing failure, but that cessation of injection stopped the problem. This practice has been discontinued and all brine is now disposed of on the flanks of the dome. 


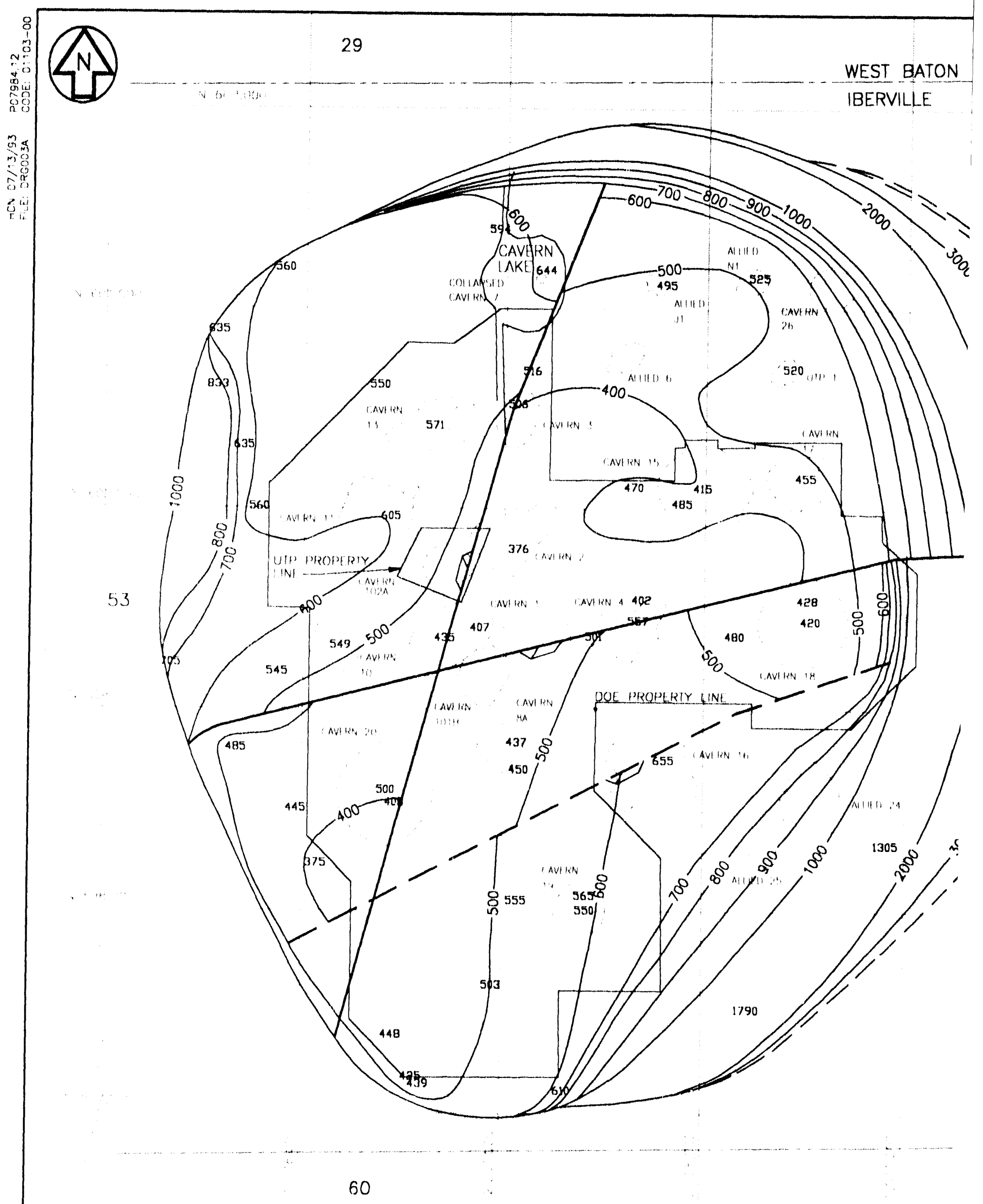




\section{IFAEND}

PARISH

$5796 ?$

5796

28

(FEET BELOW MEAN SEA LEVEL)

LEASE CODES

$-5000-$

CAPROCK CONTOUR

(FEET BELOW MEAN SEA LEVEL) (DASHED LINE REPRESENTS PROBABLE CONTOUR)

$\longrightarrow$ FAULT

- - PROBABle faUlt

-...- PARISH BOUNDARY

PROPERTY LINE

CAVERN

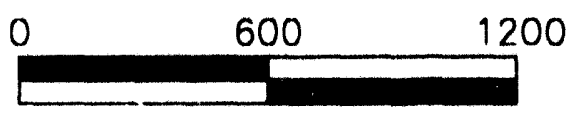

FEET

FIGURE 5

CAPROCK

BAYOU CHOCTAW SPR SITE 


\section{Salt}

As noted above, the improved mapping of the caprock surface showed a major fault transecting the entire dome (Fig. 5). This revised interpretation led to a similar mapping of the top-of-salt (Figs. 6a, 6b) along with associated faulting. Thus, a faulted top-of-salt surface is now evident and this in turn likely marks a boundary between separate salt spines; we believe it would satisfy Kupfer's (1992) nomenclature of anomalous zones. As similar features exist at other domes having cavern storage, this anomalous zone would not necessarily have a significant impact on the deeper SPR caverns

The shape of the salt has been modified only slightly based on new data (Fig. 6b). The critical west-side overhang that limits DOE storage has been extended south and minor anomalies removed by new well control since the New Orleans geological Society Map of 1961, and subsequent updates such as the 1980 DOE characterization and PB-KBB's mapping for Union Texas Petroleum.

As with the caprock map, the southwest corner is a structural high, suggesting that this part of the dome is rising faster than other parts. The reentrant of the $900 \mathrm{ft}$ contour in the northwest corner may also be structurally controlled. Similar troughs have benn noted at other domes, e. g., Weeks Island, LA, and Big Hill, TX, SPR sites.

In drilling the well to leach Cavern 26, Union Texas encountered black shaly material somewhere between 3690 and $3819 \mathrm{ft}$. This was interpreted as an overhang, but our interpretation of a vertical seismic profile conducted for them, and with the gravity data, does not confirm that geometry. The refraction data from the VSP clearly shows the east face of the salt stock leaning to the west (dipping eastward, as shown in all the surrounding wells which tagged salt), while reflections could not be tied to the black shale, suggesting it is an inclusion of material from the outside. The first sonar profile of Cavern 26 was normal, but further leaching could indicate an anomaly on this flank.

The salt cored for Cavern 101 is clear with $1-2 \mathrm{~cm}$ crystals and $1.2 \mathrm{~mm}$ gray anhydrite bands down to $2390 \mathrm{ft}$ depth. The core taken at $4741-4745 \mathrm{f}$, was black, $\sim 5 \%$-anhydritic salt with $0.5 \mathrm{~cm}$ crystals and wavy vertical bands up $101 \mathrm{~cm}$ wide. Both of these types of salt are common in Gulf Coast domes, the clear coarse-crystalline salt typical of the centers of spines being more common at shallow depths, apparently because of recrystallization with release of pressure uplift; while the black salt is typical of the edges closer to the anomalous zones. The inclusions measured in Fig 6.24 of the 1980 characterization report are another function of the same increase in insolubles with depth

\section{Structural Interpretations}

Five new cross-sections have been prepared, showing domal geometry and structure (Figures $7-11$ ) along principal azimuths. These sections show the relations of the storage caverns to the main fault cutting the caprock and shallow salt; this fault is believed to mark the anomalous zonc separating the principal spines in the salt stock. In addition, the sections show 

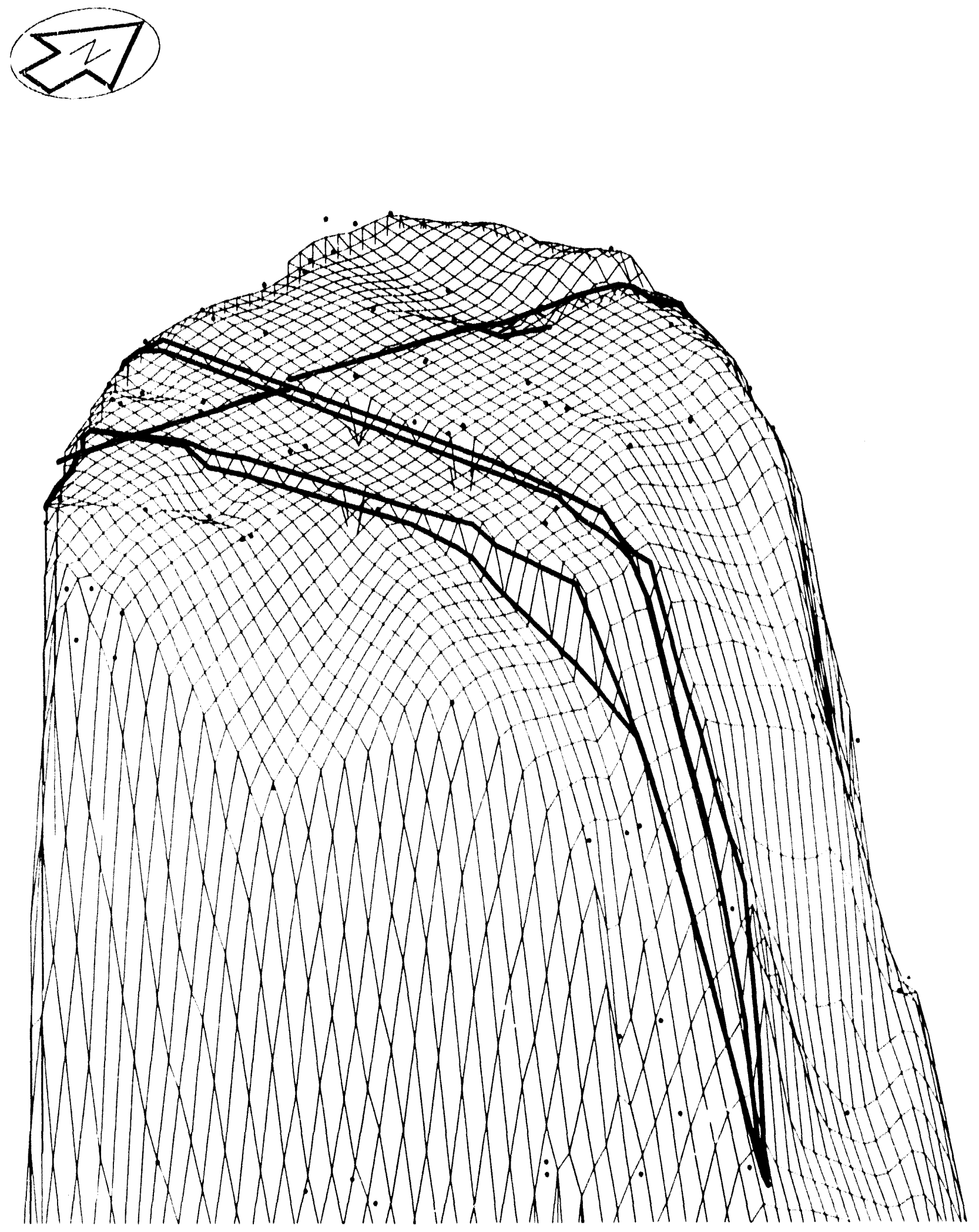

FIGURE 6a

Surface Model for Top of Salt

Bayou Choctaw Salt Dome 


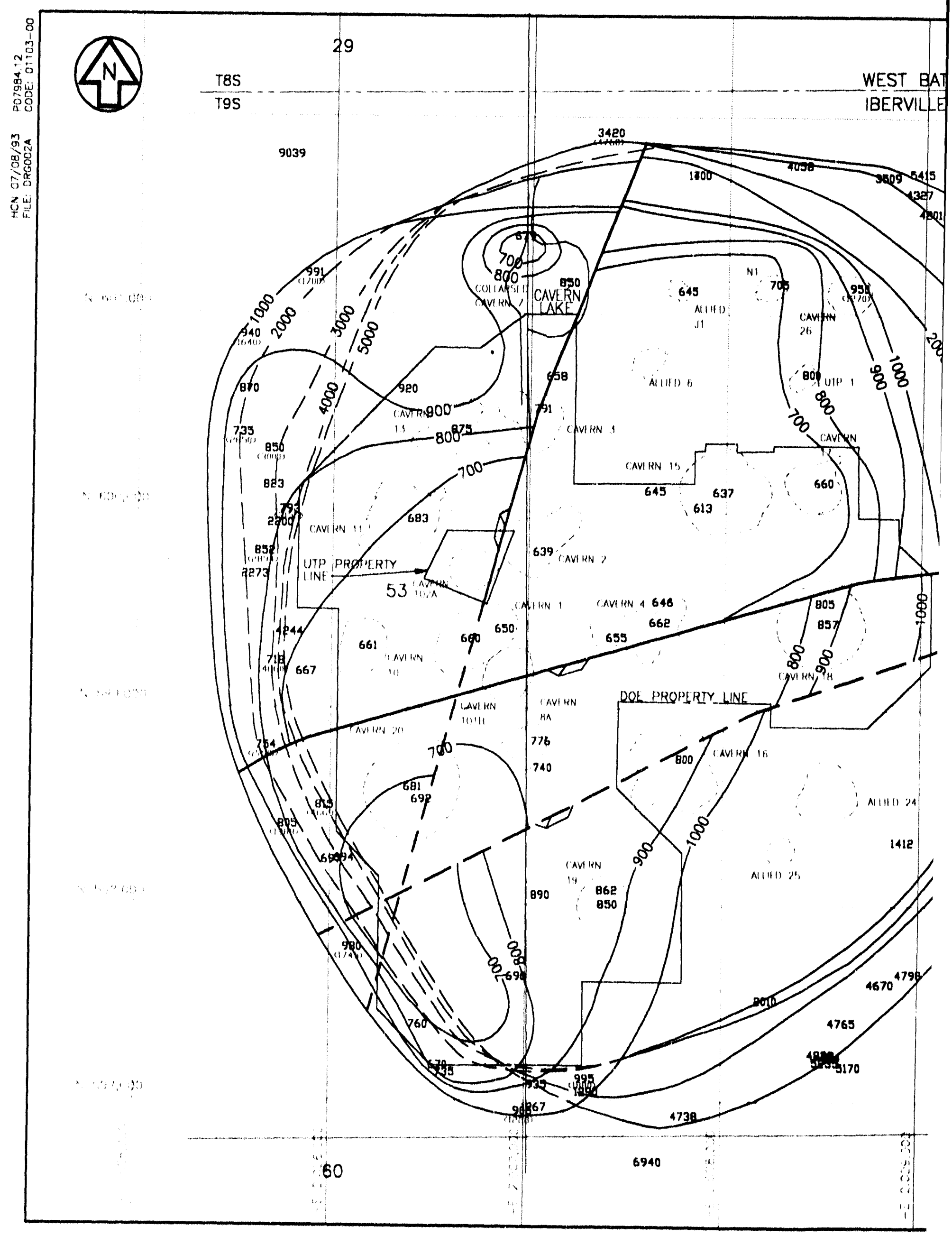




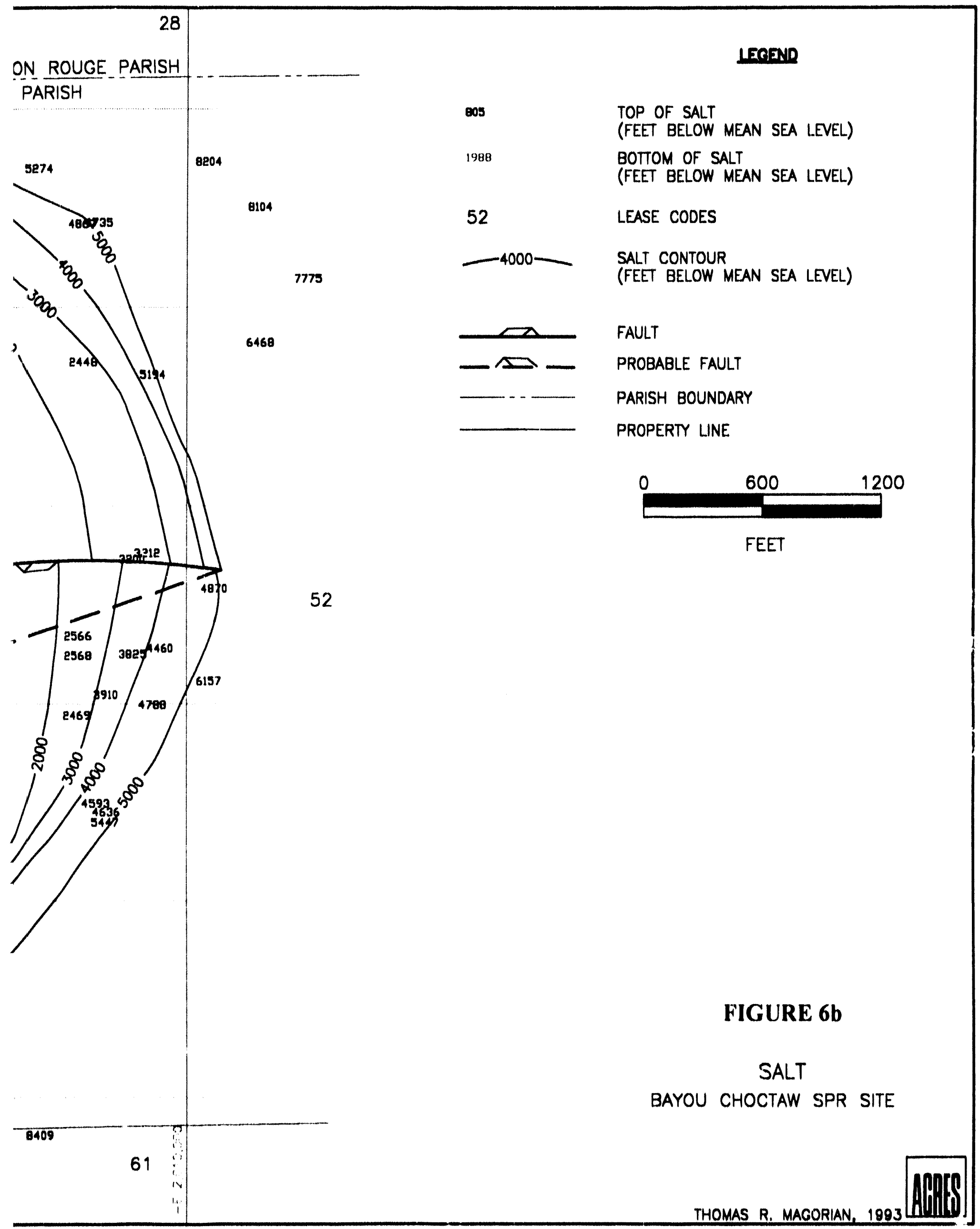


the relations of the sediments to the salt on the flanks of the dome and from which the geometry of the salt stock has been deduced. This knowledge of dome geometry allows assessments to be made of storage cavern safety

Section 1 (Fig. 7) is an east-west view through the center of the dome, and shows essentially the same features as Section G-G' in the 1980 report, although the latter trended slightly northwest-southeast. The new section is simpler and does not attempt to delineate very minor flank faulting, as suggested along the eastern flanks in the 1980 report. Fault F-2 in the 1980 report offset the caprock at the western edge of the dome by some $100 \mathrm{f}$; the revised interpretation suggests this fault probably does not cut ihrough the salt into the overhang. This kind of fault cutting through a salt overhang is known best at Stratton Ridge, TX, and has a much larger displacement on the top of the salt than any of the Batou Choctaw faults. The major fault that is shown on the caprock and salt maps (Figs. 5 and 6) crosses the section about at the vicinity of Cavern 4 and is likely responsible for the elongation of the cavern.

The westward tilt of the entire dome is most evident on Section 1, leaving most of the undeveloped salt in the northeast portion. The small remnants of caprock found deep on the east flank may not be as continuous as shown. They are relicts of old erosion surfaces on the salt, builed by subsequent deposition. The caprock is thickest at the edges of the flat top of the salt stock, as in most domes. Because of the westward tilt, this makes the caprock shallowest over Cavern 18 in this section

Section 2 (Fig 8) trends north-south through Cavern 19 on the south and Cavern Lake on the north. The flanking structure is again simplified, as with Section 1. The major east-west trending anomalous zone shows appreciable fault displacement on this section. The fault in the vicinity of Cavern Lake shown in the earlier 1980 report $(\mathrm{F}-1)$ may be less prominent than believed earlier. The apparent discordant bedding on the north tlank is due to the Heterostegina reef or atoll ringing the salt stock. It has a maximum thickness of 400 feet. The north flank also shows the unconformity at the top of the Miocene, under the basal Pliocene sand, the Goliad of Texas There is almost no overall tilt to the dome in this direction, although the lip of the west overhang extends just far enough east to be cut by this section.

Section 3 (Fig. 9) trends southwest-northeast through Caverns 20, 8, 4, 15/17, and 26. The southwest overhang is very steep and shows the proximity of the dome edge outboard of Cavern 20. Cavern 26 on the northeast flank, UTP's new brining cavern, appears to have adequate buffer, although one interpretation bs a geotechnical consultant claimed that salt had been penetrated, exited, and then reentered. As noted earlier, our interpretation does not support this model.

The deep interpretation of the west-side overhang is based primarily on the uplift of the flank sediments in Freeport well 62, which was drilled to the Heterostegina limestone reef. An alternate interpretation, in which the west flank parallels the east at least as deep as $8000 \mathrm{At}$ as found in Carter (Exxon) well 19, would make the reef at least 500 feet thick. These beds could 
TABLE 1 BAYOU CHOCTAV BTRATIGRAPHIC CORRELATION CHART

Unit

Holocene: Hriminum arumum

Pleistocene

wisconsin

Alton/Peorian: Mrumelm

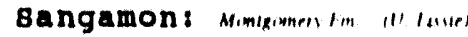

Illinoian

Yarmouthian: Henlm lim $\mid 1$ lsup

Ransan

Aftonian: Willutur $/ \mathrm{m}$

Nebraskan

Lafayete: cimmelit im

Pliocene

Miocene

Upper

Bigenerina floridana

T'extularia

Bigenerina nodosaria

Textularia stapnorl

Middle

Bigenerina humblei

Cristellaria

Cibicides carstensi opima

Amphistegina

Lower

Robulus

operculinoides

cibicides

Marginulina ascensionensis

Siphonina davisi

- - U N C N F O R M I T Y - -

Anahuac: (Discorbis "restrictod") DR oligocene

Heterostegina

Marginulina howei

Frio

Miogypsinoides

Cibicides hazzardi

Marginulina texana

pontic facies

Bolivina mexicana

Nodosatia hlanpedi
H

MII

Symbol

$a$
$s$
$i$
$(p)$
$k a / k s$
-
$n e$

Pl,

MI

$\wedge(\$ 1)$

H (S2)

L) (S3)

2

W

BHI (\$4)

CI

$\operatorname{CO}(\$ 5)$

$\mathrm{AB}$

RI. (\$6)

OH

CA (S\%)

$M A(S B)$

(s) $(59)$

$\mathrm{DR}$

(1)

Mil

F

MG

$\mathrm{CH}$

$\mathrm{M} T$

BM

NIS
Lithology

peat, muck mud

sand and gravel

mud

sand and gravel

mud

sand and gravel

mud

sand and gravel

gravel

silt, mud, and sand

mud \& sand

sand and gravel

mud

sand and gravel

mud

marlne sand

deltalc sand

mud

deltalc sand

mud

unconformity

shale

thin sands

sand

shale

marine sand

sand and shale

sand

shale

thin sand

shale

coral atoll.

sand

shale

sands

thick sand

marine sands

thin sands

near geopressure

thin oil-bearing sands 


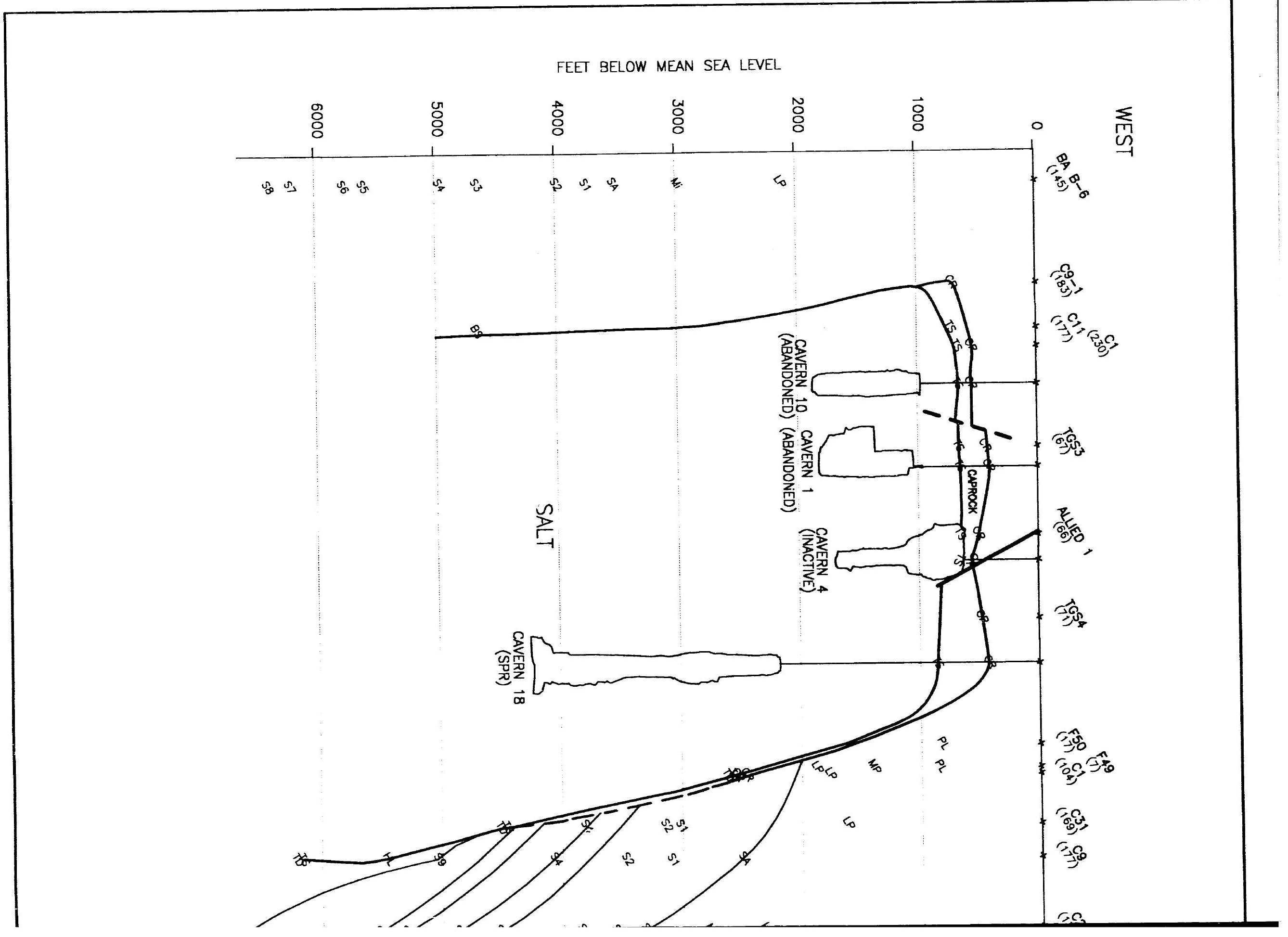




\section{LEGEND}

\section{EAST}

$\mathrm{C}^{\prime}$ WELL NUMBER

(5)

(1) OFFSET (FT', FROM SECTION LINE ROTATION SHOWN ABOVE INDICATES WELL IS SOUTH OF SECTION LINE WELLS ROTATED IN OTHER DIRECTION ARE NORTH OF SECTION LINE.

* GROUND LEVEL

$\int$ CAVERN OUTLINE

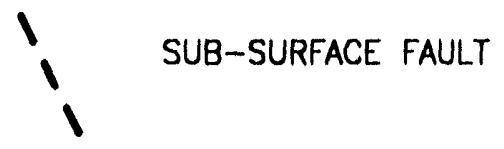

\SURFACE FAULT

GROUND LINE

STRATIGRAPHIC SYMBOLS ON TABLE 1

REFER TO FIGURE 1 FOR SECTION LINES
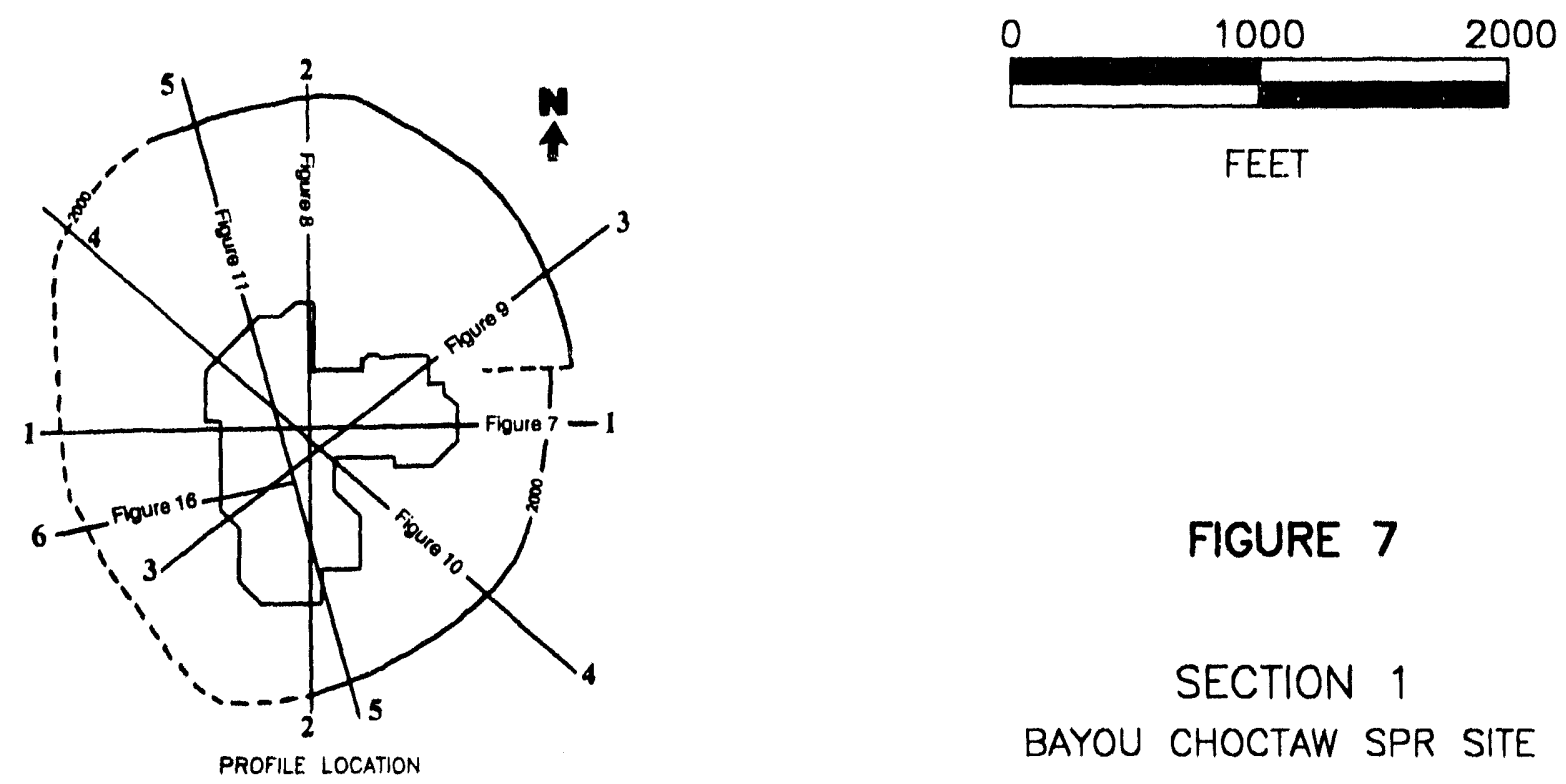

FEET

FIGURE 7

SECTION 1

BAYOU CHOCTAW SPR SITE 
SOUTH

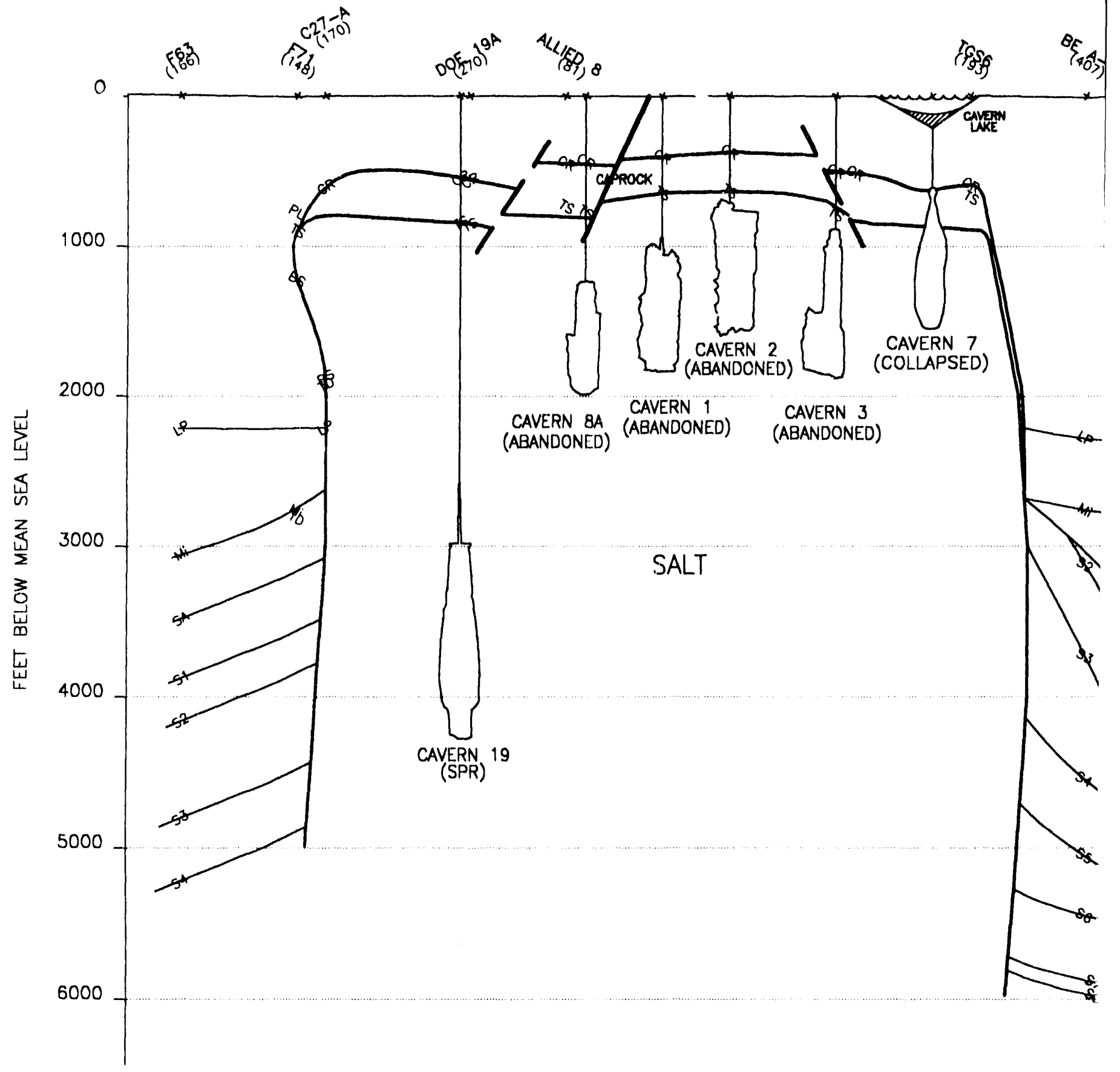




\section{IECEND}

NORTH

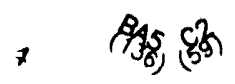

$c^{1}$

(1)

1) OFFSET (FT) FROM SECTION LINE ROTATION SHOWN ABOVE INDICATES WELL IS EAST OF SECTION LINE WELLS ROTATED IN OTHER DIRECTION ARE WEST OF SECTION LINE.

* GROUND LEVEL.

$\bigoplus$ CAVERn OUTLINE

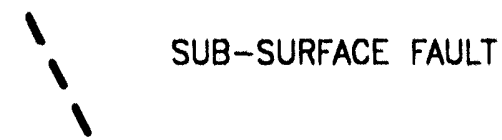

1

SURFACE FAULT

\section{GROUND LINE}

STRATIGRAPHIC SYNBOLS ON TABLE 1 REFER TO FIGURE 1 FOR SECTION LINES

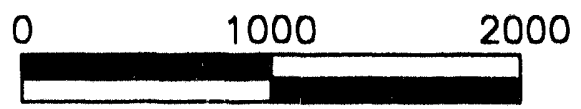

FEET
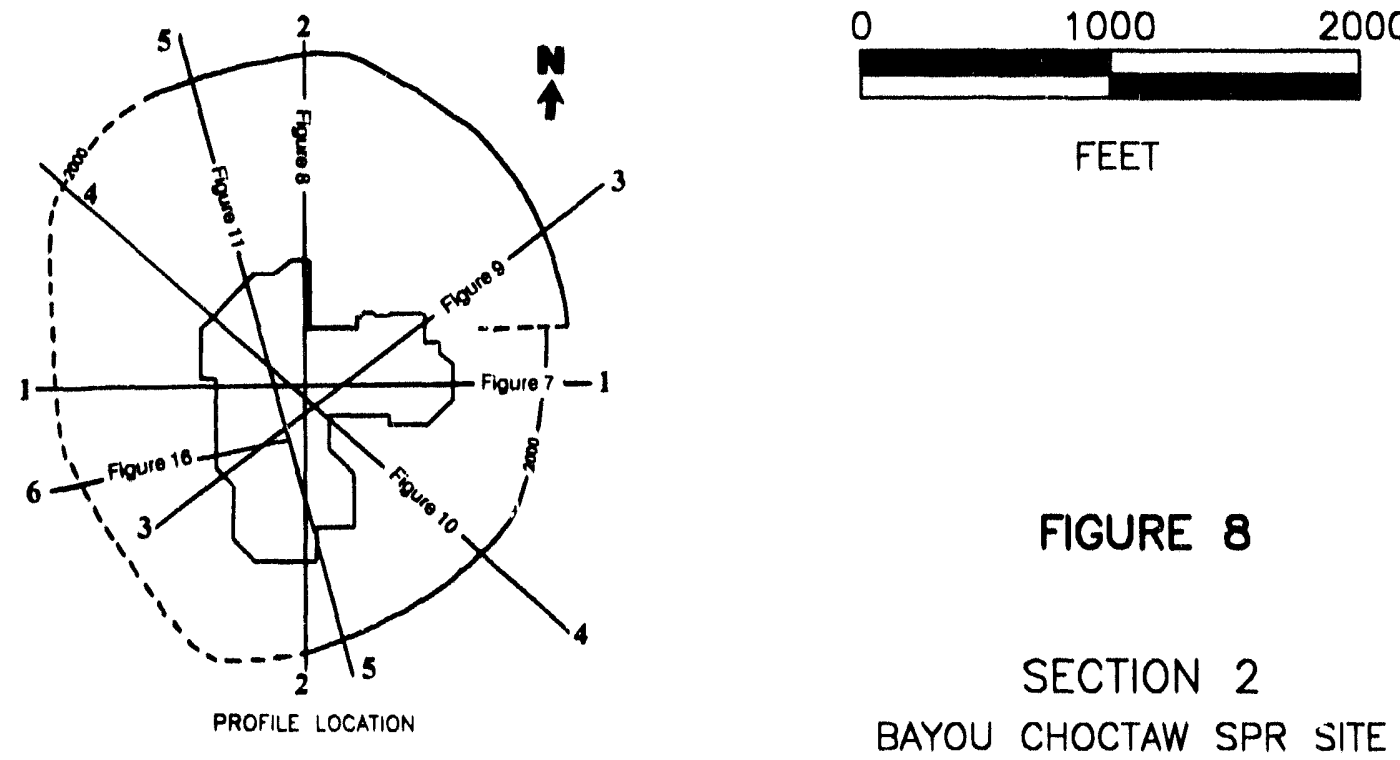


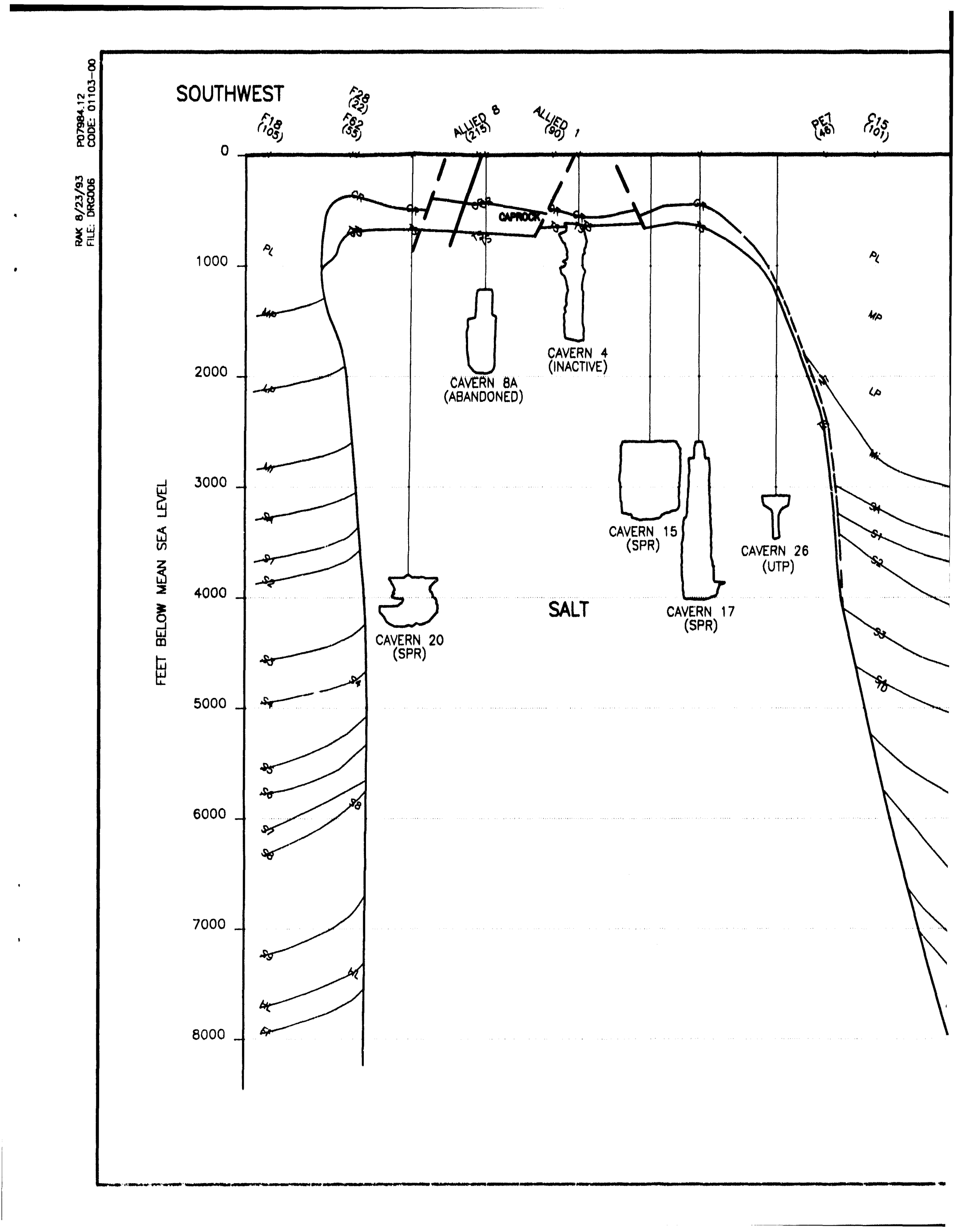




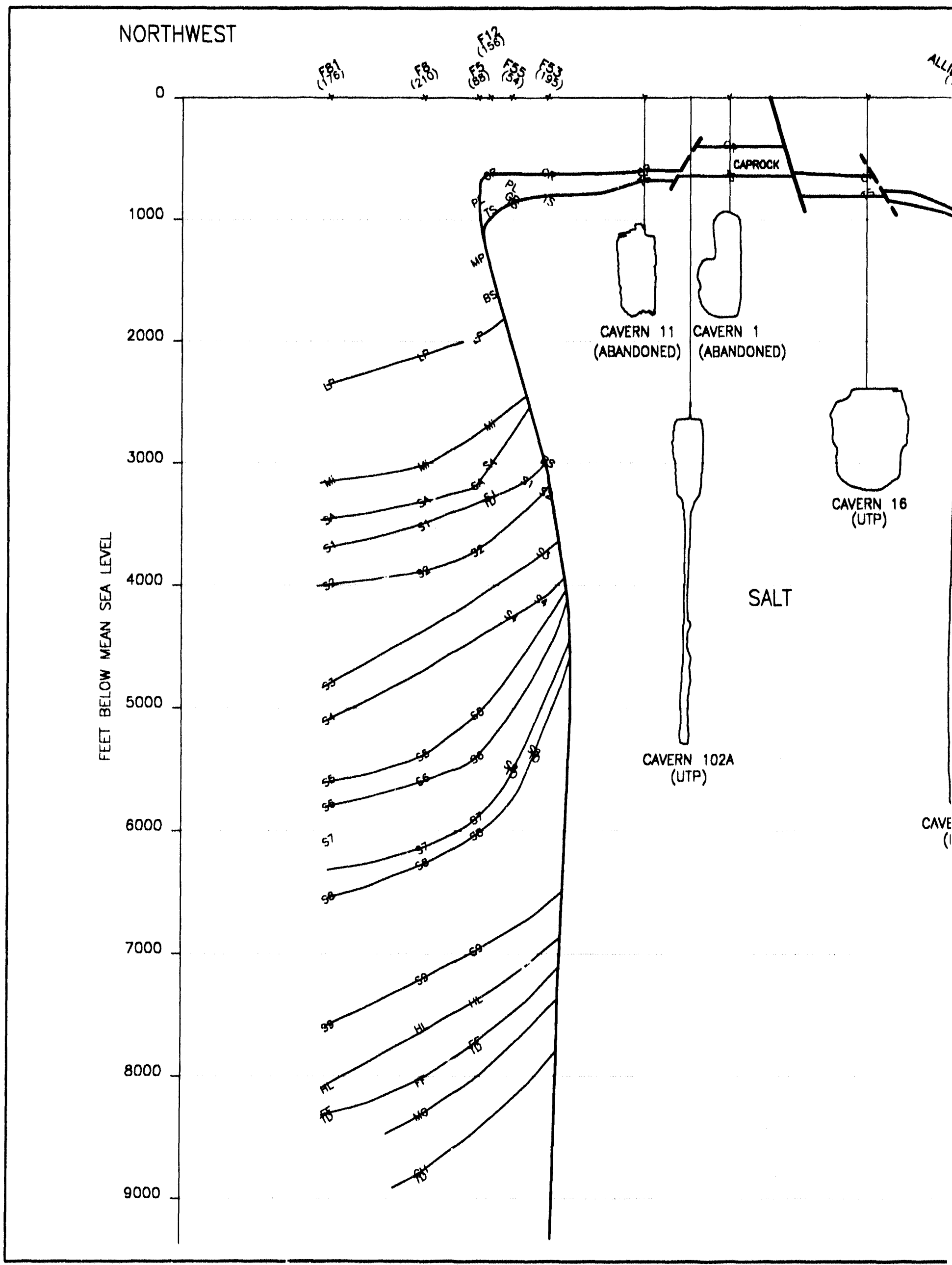




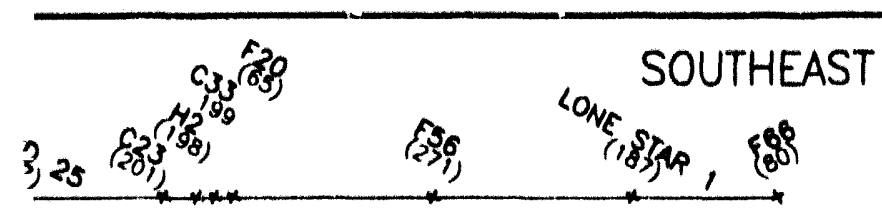

B

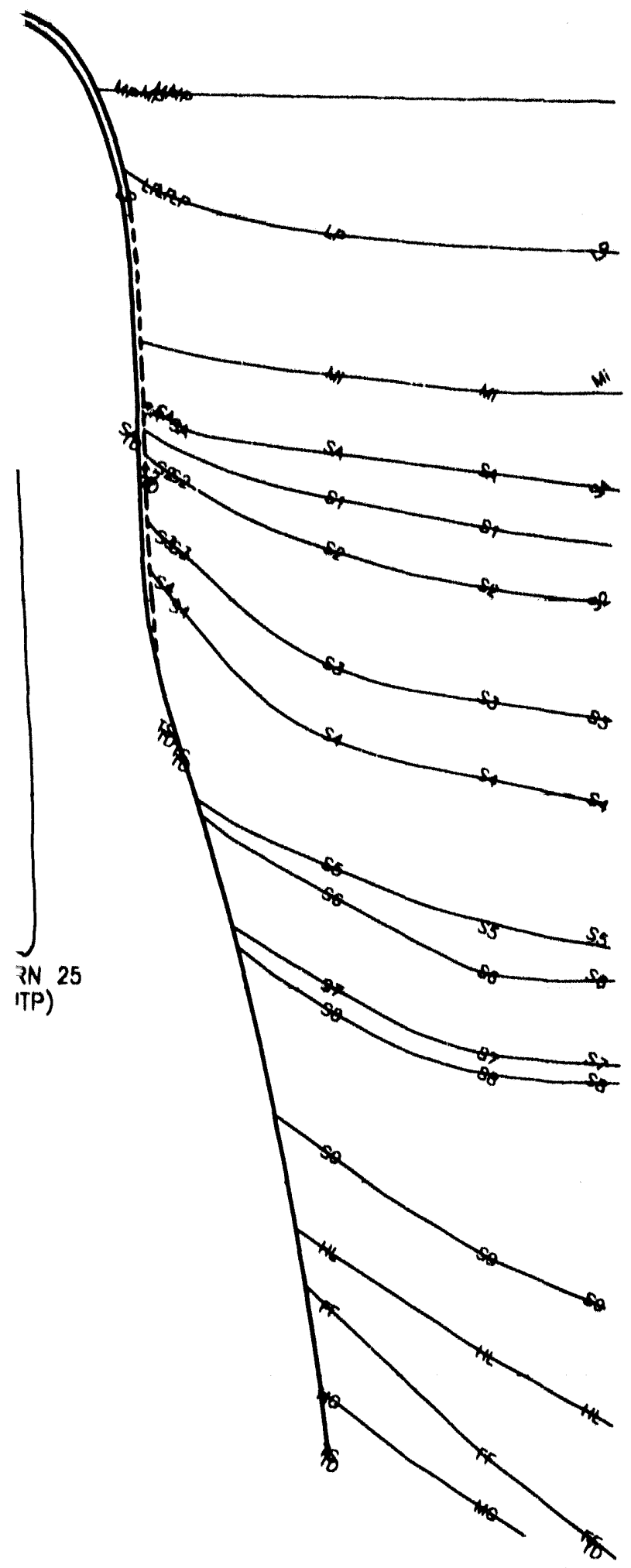

IECEND

is WELL NUMBER

1) OFFSET (FT) FROM SECTION LINE ROTATION SHOWN ABOVE INDICATES WELL IS NORTHEAST OF SECTION LINE WELLS ROTATED IN OTHER DIRECTION ARE SOUTHWEST OF SECTION LINE.

- GROUND LEVEL

D CAVERN OUTLINE

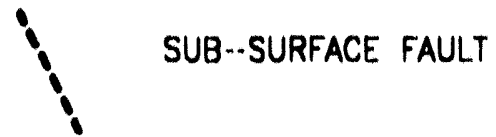

1

SURFACE FAULT

GROUND LINE

STRATIGRAPHIC SYMBOLS ON TABLE

REFER TO FIGURE I FOR SECIION LINES

0

1000

2000

FEET

FIGURE 10

SECTION 4

BAYOU CHOCTAW SPR SITE 


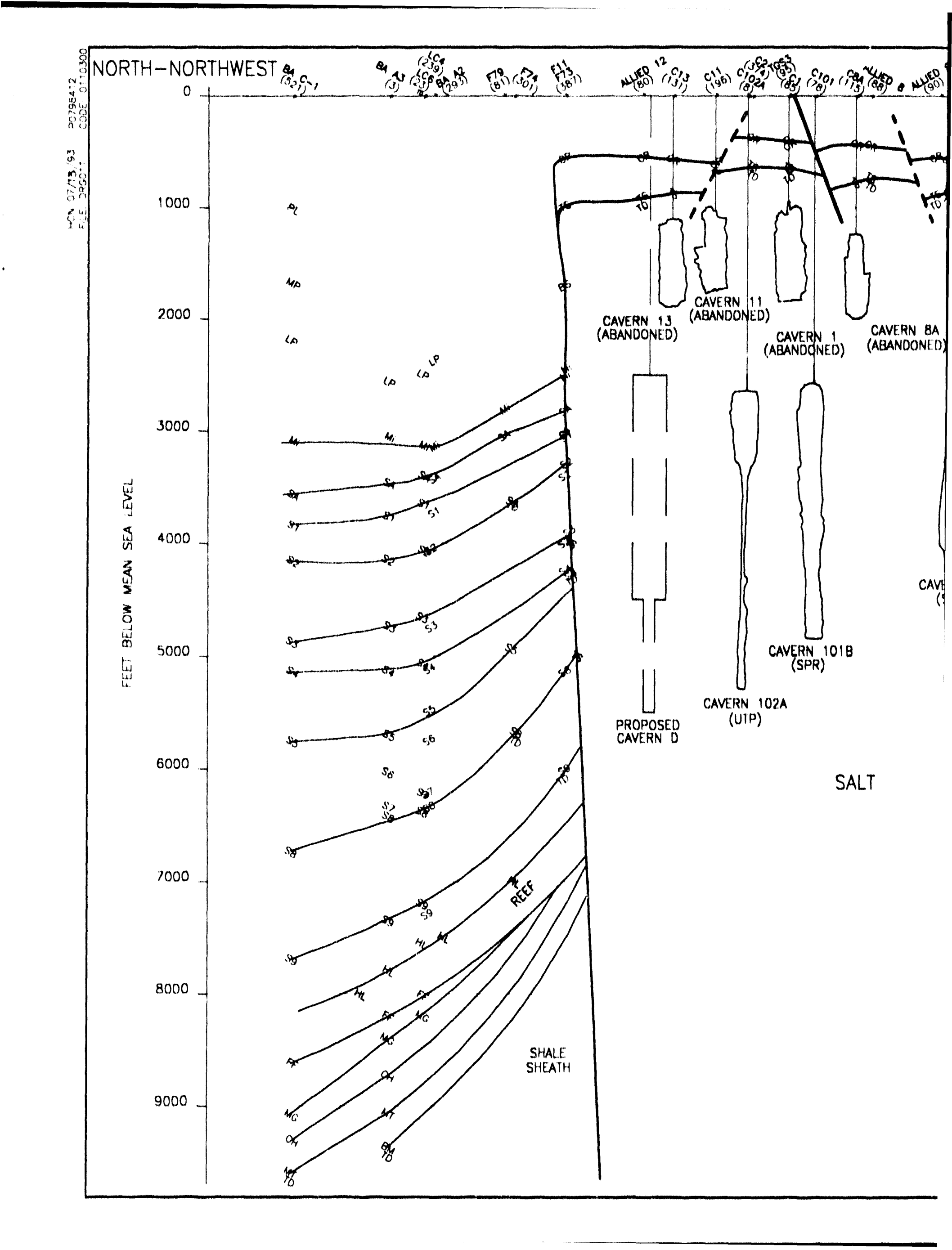




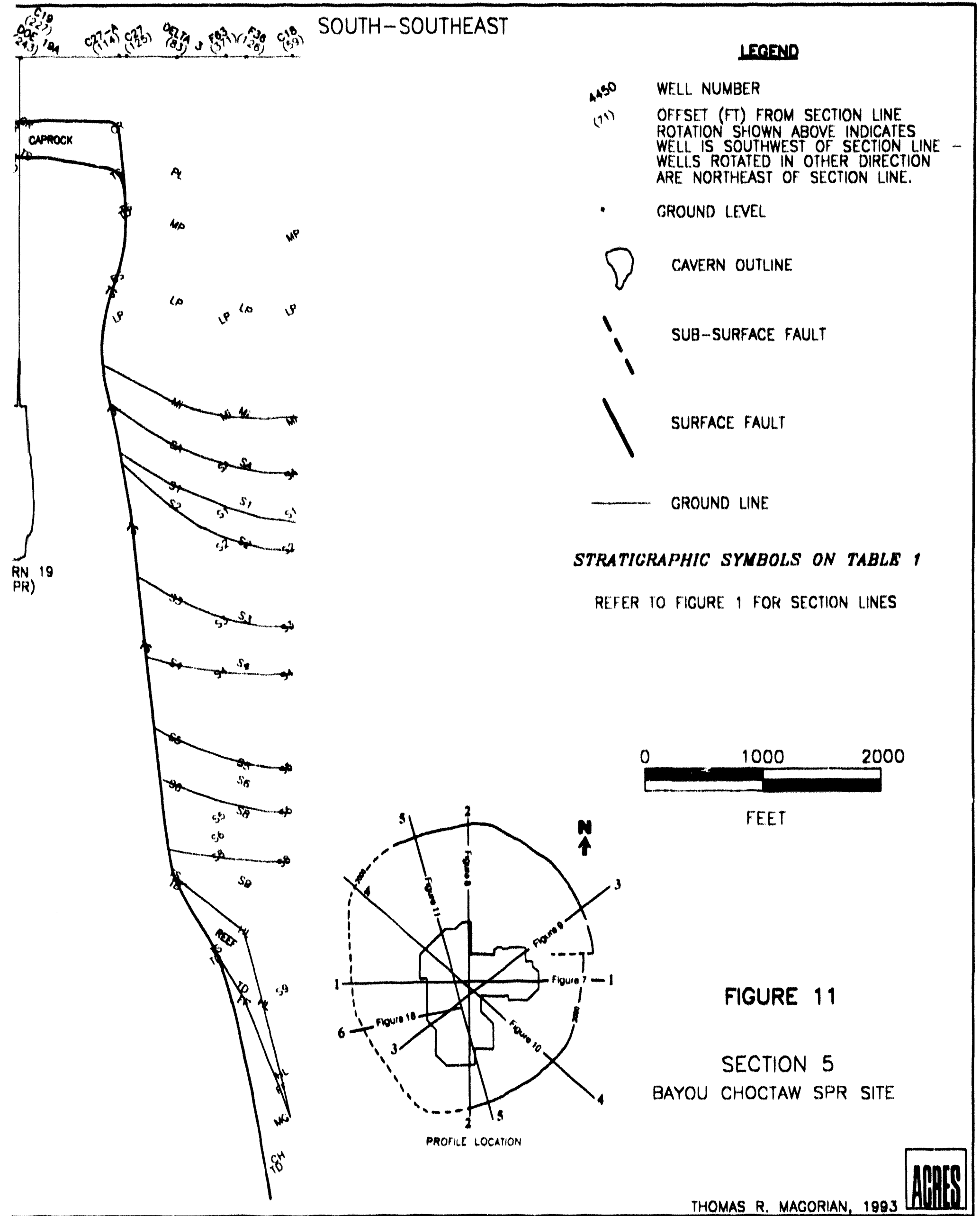


contain considerable quantities of "attic" oil, which has been explored in several deviated holes under the overhang, but never found Cavern 20 is just above the point where these interpretations deviate

Section 4 (Fig 10$)$ is a northwest-southeast transect through abandoned Caverns 11 and I, and then through IIT' Cacens 16 and 25 There is fundamentally no difference in the flanking :structure as compared with 1980 section D-D', but the central anomalous zone and fault oftset is indicated on the revision The same uncertainty of deep interpretation occurs as on Section 3 . It affects the salt web available at the base of Cavern 102 and any other caverns along this side of the dome Fault F-7 on the 1980 scction may not exist

Section 5 (Fig 11 ) is tolated clockwise some $30^{\circ}$ from Section 4 and reveals nuances in the dome structure even with this small shilt. The crowded nature of the dome is best shown in this sertion. Proposed cavern location "D" will fill the available space. If there is a ledge at the reef level on the northwest side like that found on the southeast, the resultant necking of the salt stock is too deep to destroy this location The lip of the west overhang shows at the southenst edge of the section as a notel befween 2000 and 3000 feet south of Cavern 19

\section{SPR SYSIEM CONSIDERATIONS}

The effects of regional and local geology may influence the SPR operations in a variety of ways These aspects are discussed in the following pages

\section{Sinern Configurntions}

Fifleen active and 10 abandoned caverns exist at Bayou Choctaw, with a total cavern volume of some 160 million barrels This includes 79 MMB in SPR, 32 MMB in UTP, and abour 50 MMB in abandoned caverns. excluding Cavern 7, which collapsed in 1954 and filled with overburden. The total cavern volume has practical interest, as this void space affects total creep closure (and conse(puent subsidence) in the Bayou (hoctaw salt mass, a relatively small feature as compared with most other domes

\section{SPR Caverns}

The six operating SPR caverns are listed in Table 2; all were acquired from Allied Chemical and subsequently moditied, with the exception of Cavern 101, which was leached in 1900.91 Cavern shapes are shown diagrammatically on Figure 12, locations are shown on Figures 1, 5, and 6 , and on appropriate cross sections. An experimental approach to graphical epresentation of cavern geometry is shown al Appendix D, (avern 101 sonar results are shown in shaded relief

\section{UTP Caverns}

Union Texas Petroleum (UTP) operates seven hydrocarbon storage caverns and two brine caverns on the dome, closely interspersed with the SPR caverns, which were formerly owned by 
TABLE 2 BAYOU CHOCTAW CAVERN GEOTECHNICAL PARAMETERS

\begin{tabular}{|c|c|c|c|c|c|c|}
\hline CAVERN & $\begin{array}{l}\text { SPR } \\
\text { BC } 15\end{array}$ & $\begin{array}{l}\text { SPA } \\
B C 17\end{array}$ & $\begin{array}{l}\text { SPR } \\
\text { BC } 18\end{array}$ & $\begin{array}{l}\text { SPR } \\
\text { BC } 19\end{array}$ & $\begin{array}{l}\text { SPR } \\
\text { BC } 20\end{array}$ & $\begin{array}{c}\text { SPR } \\
\text { BC } 101\end{array}$ \\
\hline DATE & & & & & & \\
\hline STARTED & 1953 & 1955 & 1867 & 1967 & 1970 & 1990 \\
\hline CAVERN & & & & & & \\
\hline VOLUME, MMB & 16.39 & 11.31 & 17.42 & 12.24 & 8.96 & 12.92. \\
\hline TOP & & & & & & \\
\hline CAPROCK & -477 & -445 & -430 & -550 & -500 & -452 \\
\hline TOP & & & & & & \\
\hline SALT & -626 & -648 & -805 & -856 & -700 & -726 \\
\hline CASING & & & & & & \\
\hline SEAT & -2405 & -2482 & -1787 & -2305 & -2100 & -2403 \\
\hline TOP & & & & & & \\
\hline CAVERN & -2605 & -2600 & -2125 & -29.35 & -3830 & -2550 \\
\hline BOTTOM & -3296 & -4023 & -4219 & -4228 & -4225 & -4830 \\
\hline CAVERN (DATE) & $(3 / 93)$ & $(3 / 93)$ & $(6 / 93)$ & $(6 / 93)$ & $(3 / 93)$ & $(6 / 93)$ \\
\hline CAVERN & & & & & & \\
\hline HEIGHT (H) & 691 & 142.3 & 2094 & 1293 & 395 & 2280 \\
\hline DIAMETER (D) & 412 & 238 & 244 & 260 & 514 & 201 \\
\hline HID & 1.68 & 5.98 & 8.58 & 4.97 & 0.77 & 11.34 \\
\hline NEAREST & & & & & & \\
\hline CAVERN & 17 & 15 & 17 & 16 & 101 & 20 \\
\hline PILLAR & & & & & & \\
\hline THICKNESS (P) & 108 & 109 & 320 & 420 & 300 & 300 \\
\hline P/D & 0.26 & 0.46 & 1.31 & 1.62 & 0.58 & 1.49 \\
\hline ROOF & & & & & & \\
\hline THICKNESS (B) & 1870 & 1052 & 1320 & 2079 & 3282 & 1824 \\
\hline$B / D$ & 4.80 & 8.20 & 5.41 & 8.00 & 6.39 & 9.07 \\
\hline DISTANCE & & & & & & \\
\hline TO EDGE (E) & 1400 & 800 & 900 & 610 & 225 & 789 \\
\hline$E / D$ & 3.40 & 3.36 & 3.69 & 2.35 & 0.44 & 3.93 \\
\hline DISTANCE TO & & & & & & \\
\hline PROPEN TY LINE & 78 & 88 & 310 & 240 & 190 & 1870 \\
\hline $\begin{array}{c}\text { WHIF EIEVATION } \\
\text { JAN } 1993\end{array}$ & 12.99 & $\begin{array}{l}10.95 \\
(4 / 91)\end{array}$ & 13.47 & 9.56 & 10.88 & 11.04 \\
\hline
\end{tabular}

Data current to July, 1993 


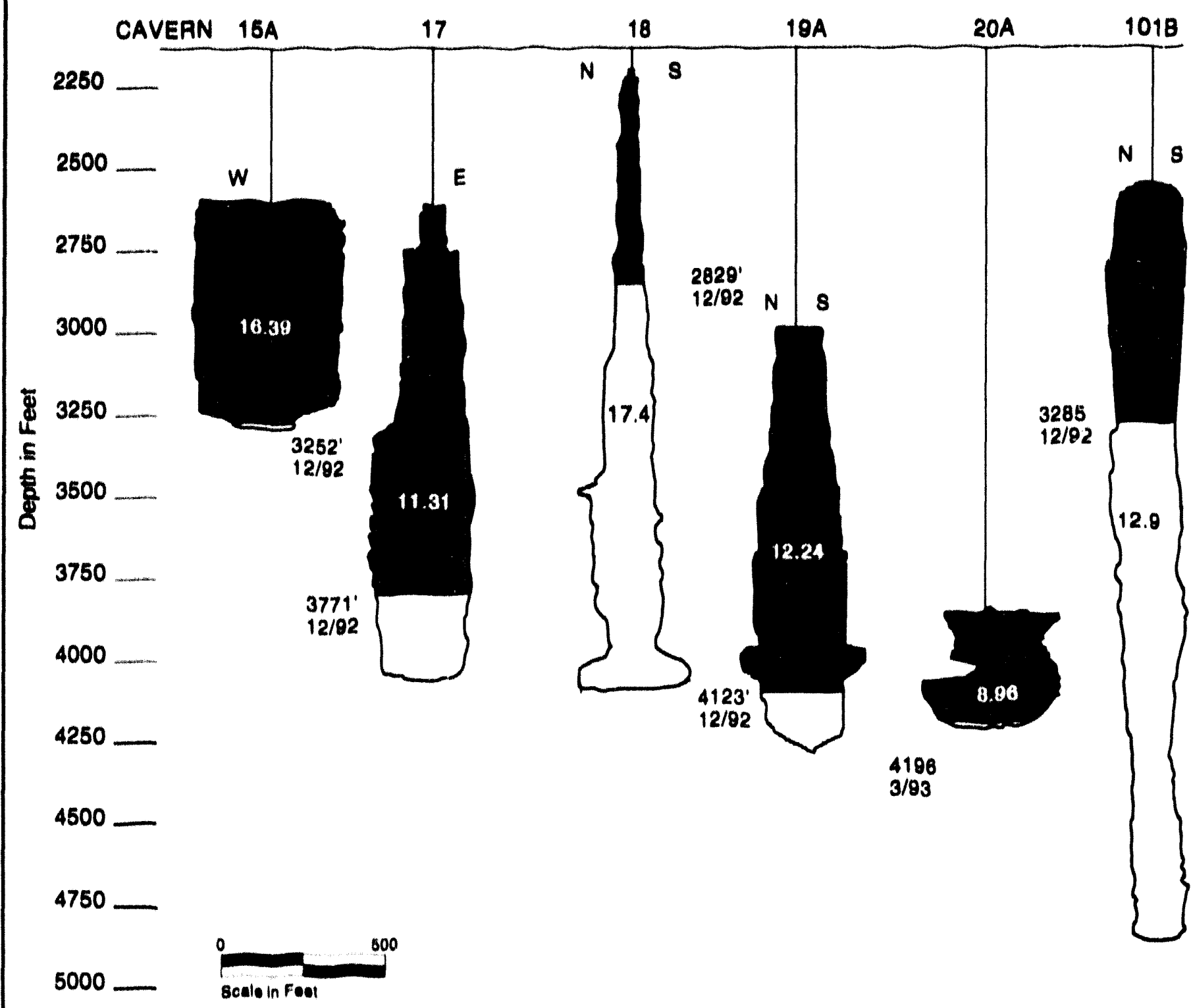

\section{FIGURE 12}

Strategle Potroloum Reserve Cavorns, Bayou Choctaw

1) Caverns shown dlagrammatically, not in true relationship to one another spatlally, except $15 / 17$

2) Refer to Figure 1 for locations.

3) Cavern volumes in million barrels, eg. 16.39

4) OII/ Brine depths in feet.

5) Vertical and horizontal scales equal. 
Allied Chemical, UTP's predecessor (Figure 1) UTP's operations on the dome support the nearby petrochemical industry, supplying feedstock to those plants.

Since the last characte.ization report in 1980, UTP exchanged their Cavern 17 for 102 , which had been constructed by DOE: They also initiated brine production in 1990 from Cavern 26 on the northeast side of the dome And in 1992 Cavern 24 was converted from brine production to ratural gas storage, it contained I O BCF of gas in late 1992 Cavern 25 could be similarly converted, but is currently in brine production

UTP's cavern parameters are summarized in Table 3 and graphically displayed on Figure 13 UTP's cavern engineering practices have been conservative and there have been no issues regarding cavern integrity

A rock mechanics analysis by PB-KBB (1991) concluded that Caverns 24 and 25 were suitable for natural gass storage provided that mechanical integrity was demonstrated and that 200 A (minimum) pillar separation was maintained, with P/D ratios greater than 10 . In 1992 the average separation was about $350 \mathrm{~A}$ and the $\mathrm{P}^{\prime} \mathrm{D}$ ratios exceeded 10 by a factor of two or more The estimated distance to the dome edge was $575 \mathrm{ft}$ for both caverns and thus the safety margins are more than adequate Because natural gas is more compressible than brine or other hydrocarbon products, creep closure and associated subsidence can be expected to increase (Heffelfinger, 1990), especially if cavern pressures are at lower values. PB-KBB [1991] recommended that UTP resume its measurement of surface subsidence, which had been suspended in 1971 after several years of monitoring very small values

Cavern o was converted from brine extraction to propylene storage in 1990) The abandoned Brine W'll 14 is located nearby, some $215 \mathrm{Al}$ away, but its condition is unknown as it has been inactive for nearly forty years. Only a small amount of brine had been extracted from two different depths, prior to its abandonment because of high magnesium The web thickness to the next closest cavern (J) is not determinable in the usual sense as there is substantial difference (10.50 ft) in the depths of the two caverns (see fig 1.3)

Cavern 25 is a possible candidate for conversion from brine to natural gas, but no immediate plans exist PB-KBB ( $|99|)$ considered the structural integrity relationships of this cavern at the same time they were looking at Cavern 24 and found very similar conditions as existed there A P/D ratio of 23.3 exists between Caverns 25 and 24 , the closest neighbor at about $250 \mathrm{fl}$

Cavern 26 is the newest UTP brining cavern, it was constructed in 1990 at the northeast edge of the dome. A possible overhang was penetrated at this location at about $3600 \mathrm{ft}$ when shale was encountered in the original borehole. The VSP survey and the well log raise questions regarding the interpretation, and it is possible that shale inclusions internal to the salt were penetrated, rather than exterior domal sheath. In any event, the shale maiks the effective limit of brining and this cavern will not ever be allowed to get very large, for reasons of conservatism. Its exterior location on the dome has little impact on any other caverns, either UTP or SPR. 
Cavern 102 was originally planned for the SPR program but was leached according to UTP specifications and swapped for Cavern 17, as it was shown during integrity testing that Caverns $15 / 17$ had some degree of pressure interaction, and would become a single gallery if leaching through the thin $(\sim 110 \mathrm{ft})$ pillar ever occurred. Engineering judgment suggested that Caverns $15 / 17$ needed to be operated at near-equal pressures and contain the same product in case of coalescence; thus the swap was arranged. Ehgartner [1993] has reexamined this issue in light of refined analytical methods; discussion follows later.

Abandoned Caverns $1,2,3,5,8,10,11,13,14$

No new information is available on these former caverns, and all of the wells have been plugged and abandoned. None of these are considered to be reclaimable for development of storage. Their history and status are fully described in the 1980 characterization report.

\section{Cavern Integrity Issues}

\section{Cavern 4 Status:}

Cavern 4 has no salt roof and also experienced erosion into the caprock prior to its abandonment in 1957, following the collapse of Cavern 7 and the formation of Cavern Lake in January, 1954. Because of similarities in the geology and cavern size, the 1980 characterization report concluded that a similar collapse could occur over Cavern 4, resulting in an $800 \mathrm{ft}$ diameter lake and affecting some of the non-critical SPR facilities. Because of this potential, several site and system changes were introduced, and a collapse warning system was engineered and installed [Todd and Smith, 1988].

Some 12 years of safe SPR operations have taken place, and although there have been no hints of instability or abnormal subsidence over or near Cavern 4 , substantial uncertainty has existed regarding the geometry of the cavern roof area, especially the amount of additional caprock removal by leaching or rockfall. PB-KBB, in its 1978 analysis of the situation, suggested it was reasonable to assume that hydrologic communication in the lost circulation zone at the caprock/salt interface would continue to promote removal of caprock over the cavern roof. This prediction was based in part on the apparent enlargement of the caprock/roof area between 1963 and 1977, as determined from sonar measurements. Between the 1977 and 1980 sonar surveys, there appeared to have been no further change of significance [Todd and Smith, 1988]. The 1977 volume estimate from sonar was about 5.85 MMB, but 1980 sonar volume measurements indicated 5.94 MMB, an increase of about $1.5 \%$-- which could represent further dissolutioning, or more likely be within the error range of the survey. Estimates from production records suggested the volume should have been approximately $14.8 \mathrm{MMB}$, a major inconsistency [PB-KBB, 1978]. PB-KBB suggested that salt solutioning not observable on sonar might be responsible for the disparity. Mills [1993] notes the plan view cross sections in the 1992 sonar report are extremely irregular and support the notion of hidden volume. The shape also makes radius and volume interpretations more difficult and variable. 
TABLE 3: Union Texas Petroleum Cavern Geotechnical Data Base, Bayou Choctaw

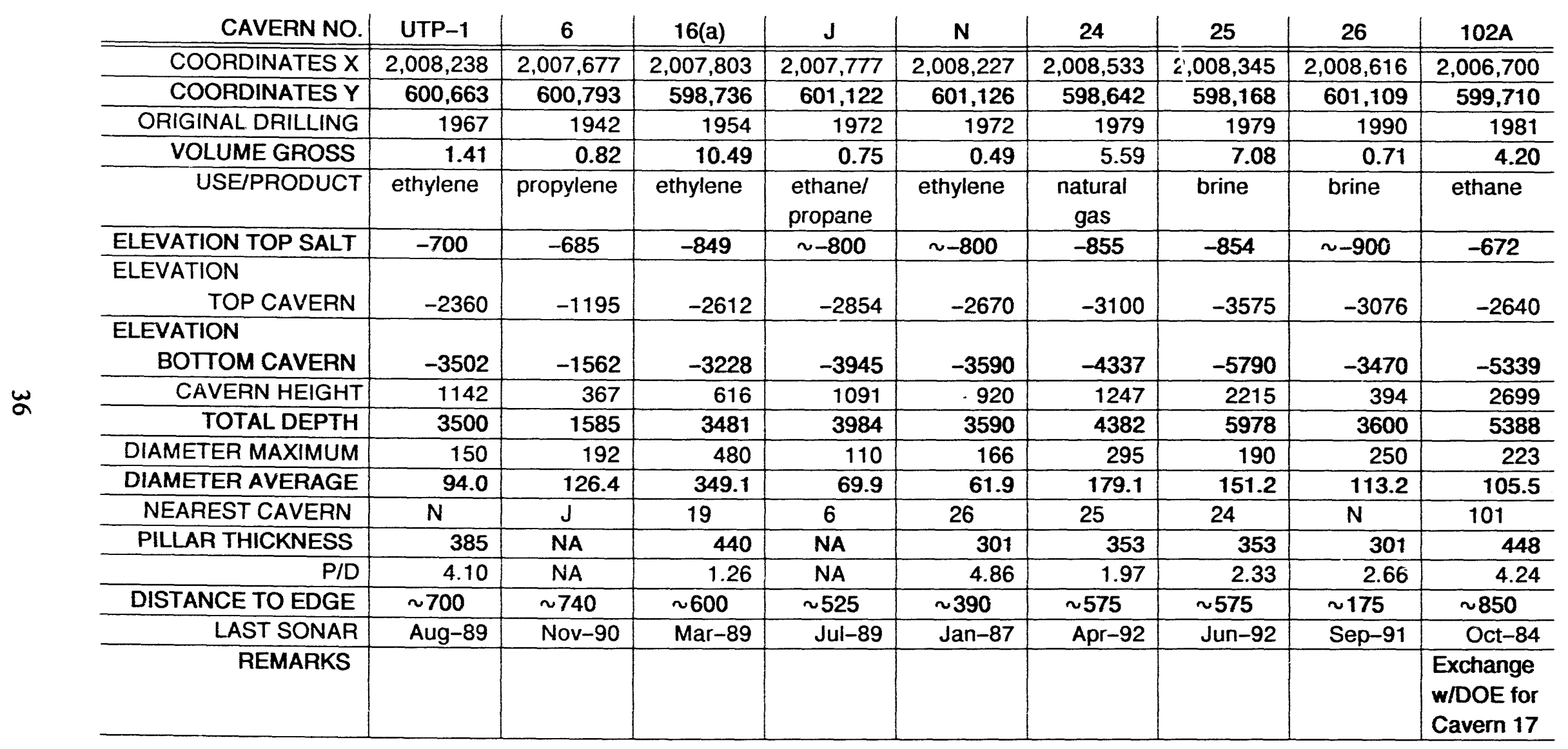

$\mathrm{NA}=$ Not applicable to these caverns because of substantial depth variation 


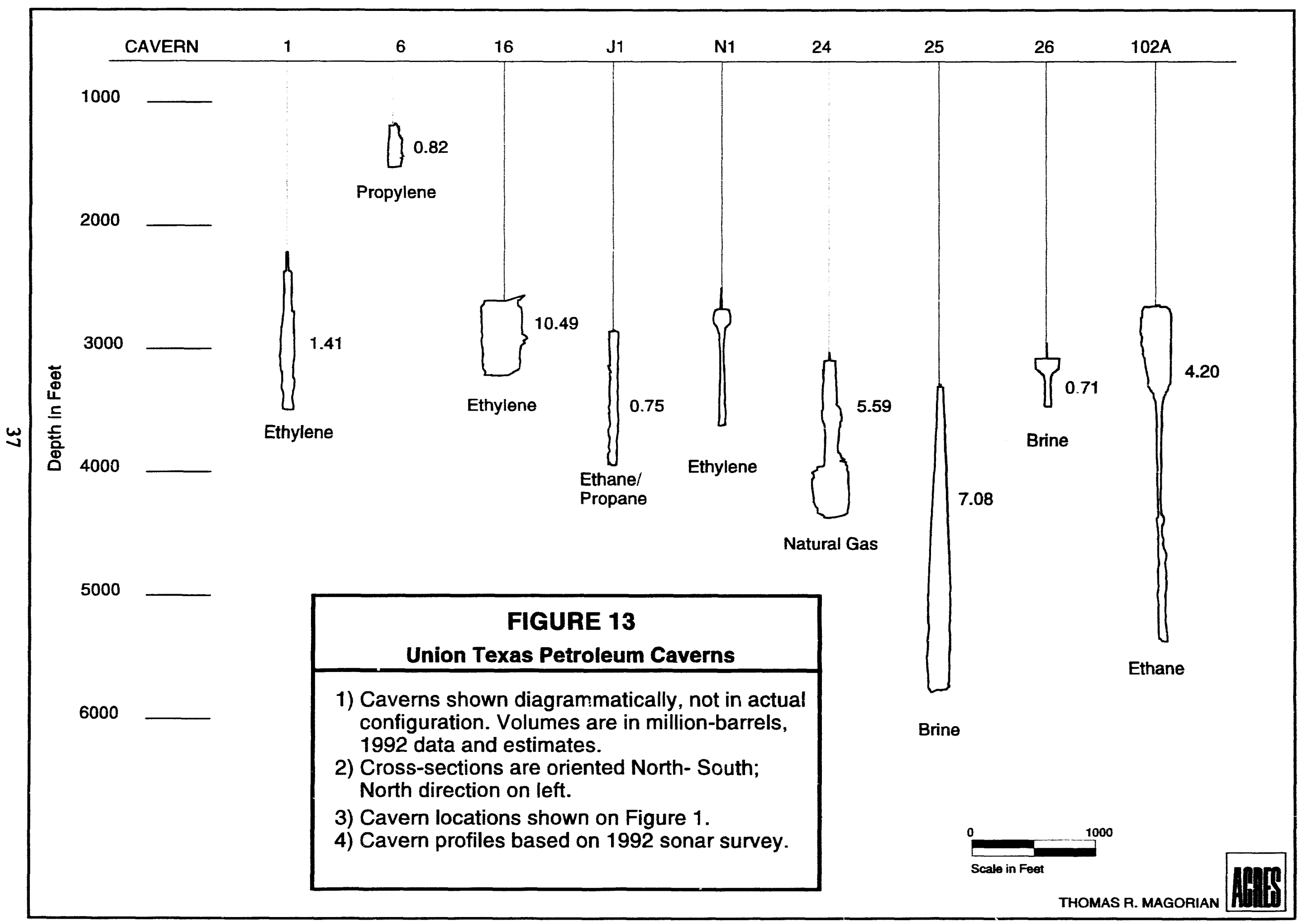


Even though there is little new information at Bayou Choctaw, there is increased understanding of anomalous zones in salt domes in general [Kupfer, 1980, 1990]. The 1980 report identified a major fault zone (F2), possibly active, that intersects the dome in the vicinity of Cavern 4. The revised caprock and salt maps (Figs. 5 and 6) clearly show the subsurface expression of this fault as it traverses the top of the dome. It is likely that this external fault is manifested within the salt mass as as a shear zone or anomalous zone, and may be a boundary between two discrete spines of salt. Such conditions could account for the pronour.ced westextending wing that appears in the sonar profiles (Figs. 14, 15). Cavern 1, $800 \mathrm{ft}$ west of Cavern 4 also has a westerly-extending wing paralleling the trend of the fault zone, possibly further substantiating the notion that an anomalous zone exists in that vicinity. The revised caprock map in this report shows this fault transects the entire dome and effectively passes directly through the cavern; also the fault azimuth is directly in line with the axis of elongation of the cavern. This correlation is apparently more than coincidence, and suggests that the enlargement potential of Cavern 4 could be influenced by the nature of materials along this fault.

To resolve some of these uncertainties, a re-sonar of Cavern 4 was conducted in August 1992 to determine what changes occurred in the caprock since 1980. The survey showed that no major change has occurred in the comparative appearance on sonar profile graphics, although there is some evidence of a roof fall about $150 \mathrm{ft}$ west of the wellbore [Todd, 1992]. The overall $6 \%$ enlargement in volumetric calculations from 1980 may indicate some additional solutioning in the cavern, although much of the $6 \%$ can be attributed to the expected survey inaccuracy and allowable error. Another factor to consider is that cavern creep closure should have reduced the volume by about one percent over the 12-yr period between surveys. About one-third (150,000 bbl) of the reported $6 \%$ increase from 1980 is at or above the $-600 \mathrm{ft}$ level. Slezak [personal communication, 1992] cautions that the several surveys are not comparable in that different tools were used; the 1963 survey apparently employed only horizontal look angles, and the volume at the top of the cavern above $-648 \mathrm{ft}$ is not included in the reported cavern volume, even though the horizontal accuracy was more precise. Todd [1993, Appendix C] considered the evidence and concluded that there is no basis to believe that significant change occurred between 1980 and 1992.

Thus a degree of uncertainty remains, and shows that some caprock dissolutioning may have occurred during the preceeding 12 years. If change could be proved to have occurred, possible stabilization measures might be considered and mitigation instituted. But little additional action seems justifiable at this time in view of the facts as are known. The injection of grout into the remaining overlying caprock and overburden roof is one course of action that might be considered at a future date, but this may be impractical. The authors of this report believe a resonar of the cavern would be prudent in about three to five years, providing a rational basis for planning

\section{Cavern 15/17:}

An exchange agreement between Allied Chemical (now UTP) and the Department of Energy was reached in November, 1982, wherein Allied's Cavern 17 was exchanged for DOE's newly leached Cavern 102. Originally, only Cavern 15 was purchased for SPR, but it was soon 


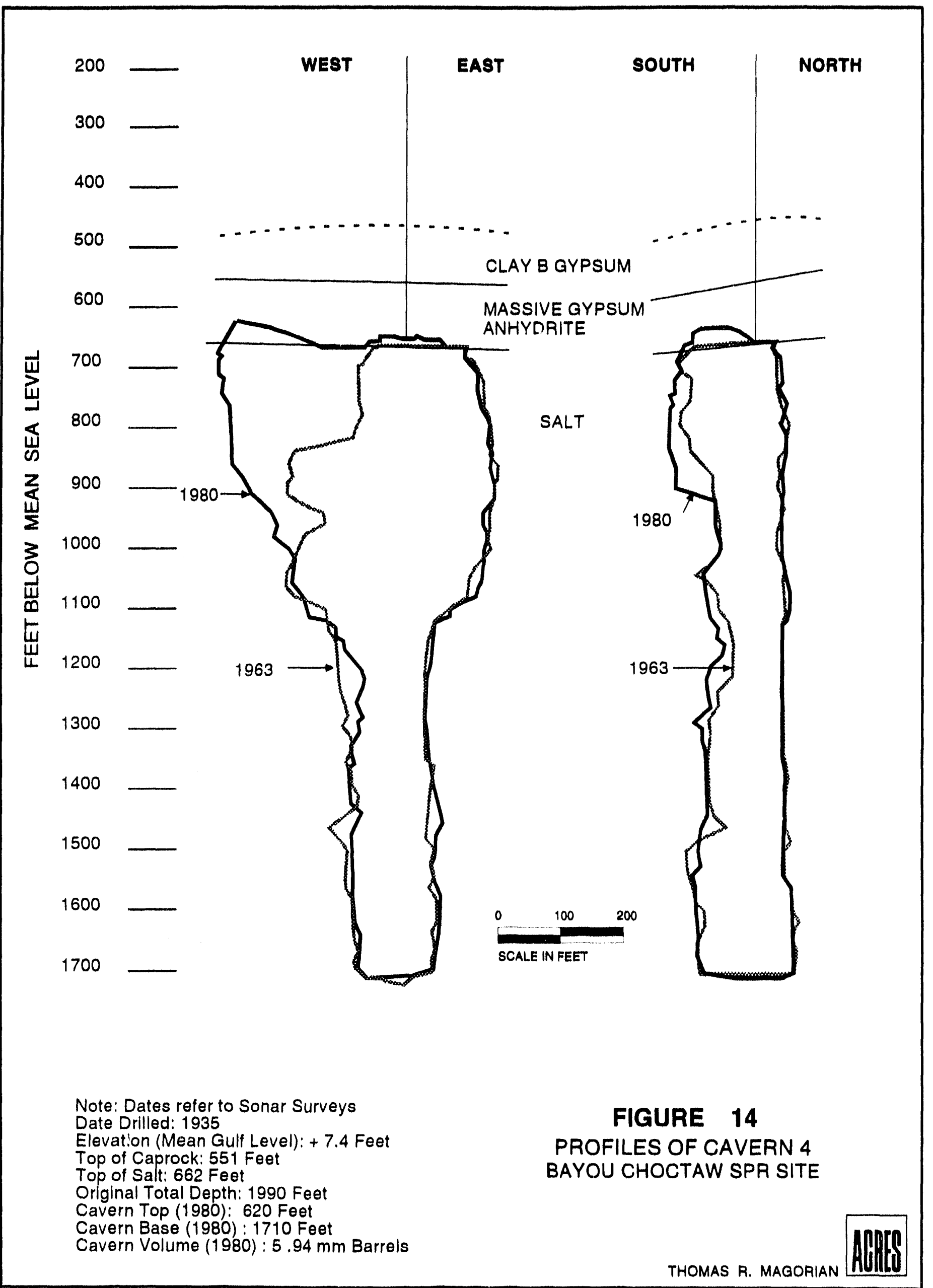




\section{VERTICAL CROSS SECTION}

Boeing Petroleum Services, Inc. Well No:4

Bayou Choctaw Site

\section{Woll No.4}

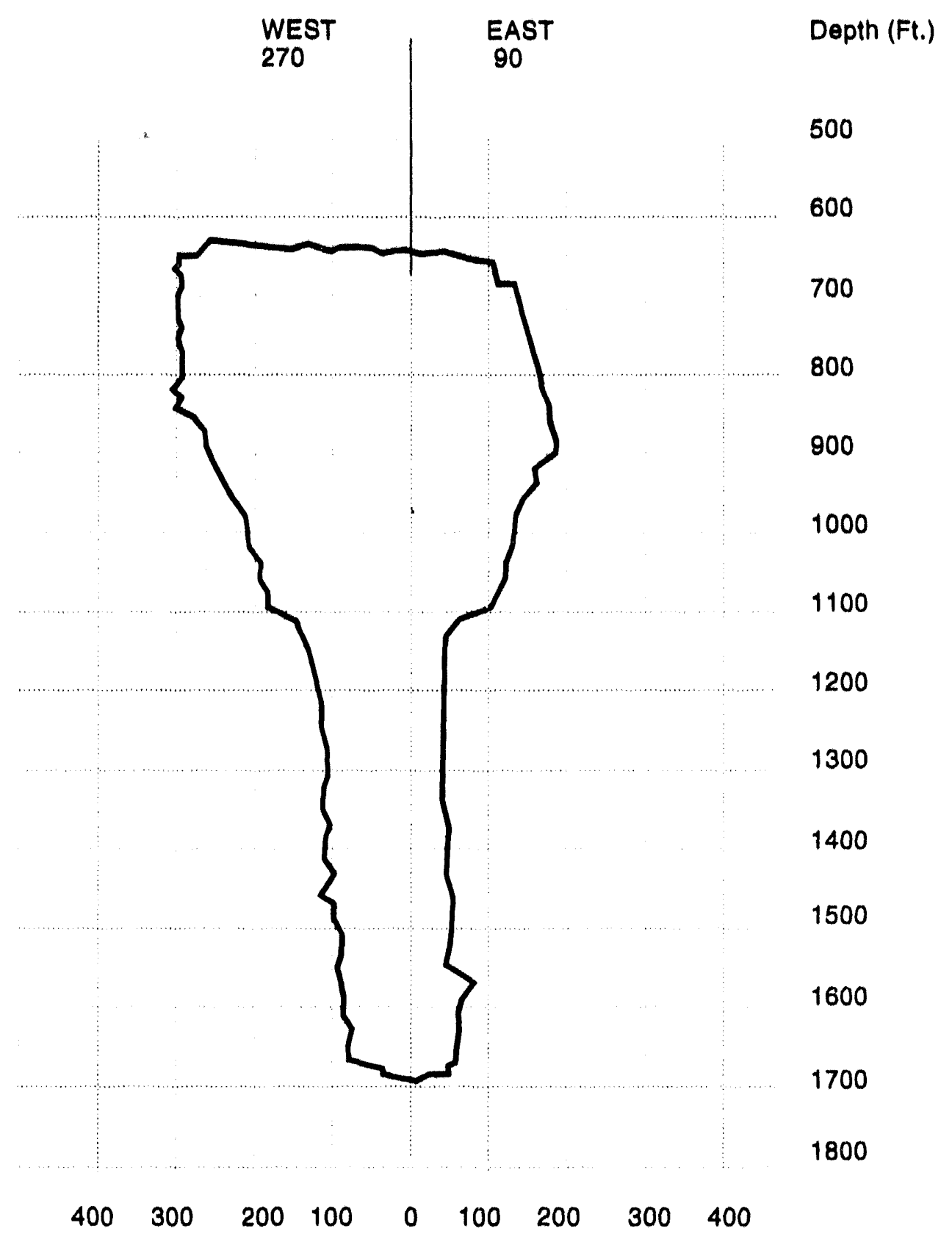

FIGURE 15

PROFILE OF WELL 4 BAYOU CHOCTAW SPR SITE

Sonar Survey $8 / 6 / 92$ performed by BPS 
realized that differential pressures between Caverns 15 and 17 (containing ethane) could effect the stability of the already thin salt web separating the caverns.

These two caverns at closest approach are within about $110 \mathrm{ft}$ of each other (Fig. 12). This is not anticipated to be a problem for SPR storage as additional drawdown and refill cycles may eventually coalesce these caverns. However, there is some uncertainty regarding the actual web thickness, and it does affect the manner in which the caverns are operated. Presently the two caverns are operated at near-equal pressures, but during integrity testing in 1985 [Goin and Buchanan, 1986] believed there was indication of possible pressure communication, as anomalous responses were observed during integrity testing when unequal pressure existed between the two caverns. This suggests that the web could be somewhat thinner than the $-100 \mathrm{ft}$ that sonar profiles imply. Or possibly there is some fracturing or physical connection in the salt that is responsible for the anomalous pressure readings

A 2-D plane strain analysis of the salt web between the caverns [Ney, 1979] showed that when Cavern 15 was depressurized while Cavern 17 had a wellhead pressure of 1250 psig, a tensile area occurred on the Cavern 15 side of the web. However, when the model assumed a $150 \mathrm{ft}$ web thickness, no tensile area occured. Thus, based on this analysis, the present thickness would appear to be only marginally acceptable

Ehgartner [1993] studied the question of web behavior, using more recent calculational methods which had been validated with underground data from the Waste Isolation Pilot Plant [Munson, et al, 1989]. Web stability was evaluated for the current, mature condition ( $-30 \mathrm{yrs})$, and after three successive 5-yr intervals of drawdowns and workovers. The simulation assumed an initial web thickness of $156 \mathrm{ft}$ at $3000 \mathrm{f}$ depth, and considered representative conditions that are apt to occur in such an operating environment, even though hypothetical.

Ehgartner's results of web stability suggest a compressive failure mode rather than tensile failure as previously thought. At the end of the three drawdowns, web thickness had diminished to $56 \mathrm{ft}$ and was predicted to breach. Workovers of Cavern 15 most affected web stability and decreased safety factors to one and below (a 30 to $40 \%$ reduction), whereas workovers of Cavern 17 only decreased safety factors by $3-5 \%$. These comparative values show that it is significantly more important to maintain pressures in Cavern 15 than in Cavern 17. The results also showed that drawdowns initially improved the minimum safety factor in the web by approximately $20 \%$ by leaching away the highly strained salt at the cavern walls. But the narrower web also crept faster than before the drawdown, so the benefit was temporary. For the simulated history, the minimum post-drawdown safety factors returned to the minimum pre-drawdown values after about 0.5 to 2.5 yrs. Ehgartner [1993] suggests that when failure of the salt in such metastable web situations is anticipated, leaching to remove the highly strained salt may be beneficial. For example, leaching could prevent a failed portion of the web from damaging a hanging string as it falls, but at the expense of a shortened web life.

A re-sonar of these caverns might clarify some of the geometric uncertainties that affect calculations, but would need to be accomplished during a drawdown cycle, or else when sonar-inoil techniques become routinely possible and credible. R.outine integrity testing was completed in 
1993. At this time no other actions are indicated in changing operating procedures for these two caverns.

\section{Cavern 19:}

A lowering of the concrete pad surrounding the wellhead sumps was noted around both cavern wells in 1988. By 1990-91 the separation between the pad and the sumps had increased to as much as five inches, but apparently stabilized and had not progressed any further as of December 1992. Because somewhat larger than average (for the site) subsidence values had been noted previously around Cavern 19 [Goin and Neal, 1988], concern was commensurately greater. However, the measured rate of decrease in subsidence at these wellheads has not changed at all, so this condition seems to involve only the pad. It seems probable that this pad lowering may be related entirely to underlying soil compaction, possibly combined with decaying organic materials. Continuing surveillance of this condition is ongoing, and no further action is required at this time. There is no indication that this condition is related to the cavern below.

\section{Cavern 20:}

Cavern 20 was leached very close to the edge of the dome, approaching within approximately $135 \mathrm{ft}$, according to sonar and well records [1980 characterization report and BPS Cavern Data Base]. Mills (1993) noted that directional deviation surveys in Cavern Well 20A showed a drift of $90 \mathrm{ft}$ eastward and $70 \mathrm{ft}$ northward at a depth of $3826 \mathrm{ft}$ (the point near the cavern roof from which the sonar tool was suspended). This indicates that the earlier sonar profiles plotted from the surface showing maximum cavern extent may have effectively decreased the true web thickness from the western dome edge by $90 \mathrm{ft}$; thus the revised thickness is about $225 \pm 50 \mathrm{ft}$. This web thickness is critical because either value (135 or $225 \mathrm{ft})$ effectively limits the cavern to one drawdown cycle, unless only the upper reaches of the cavern above 4,000 $\mathrm{ft}$ are cycled. However, any additional safety factor is beneficial. Existing sonar records are probably sufficiently accurate to map the cavern interior dimensions, but, the external dome geometry and salt quality might be mapped better with modern seismic profiling techniques. Results of such surveys could improve the understanding of operational limitations.

A profile section through Cavern 20 (Figure 16) shows its relation to the overhang; it is the closest cavern to the edge of the salt, with the possible exception of UTP Cavern 26. All of the oil wells drilled along this portion of the overhung west flank of the dome are shown projected into the line of the section: Carter (now Exxon) 16 and Freeport 21 and 25. At the maximum extent of the cavern, just below $4000 \mathrm{ft}$ depth, the edge of the salt is $100 \mathrm{ft}$ farther east than originally believed, plus or minus $50 \mathrm{f}$, the inherent accuracy of the well deviation surveys $(2.5 \mathrm{fl}$ in each well). The projection shows a scatter of less than 50 feet. The smooth shape of the overhang is apparent with its westernmost extent near $2500 \mathrm{ft}$ depth

The 1980 report also showed faults on the dome periphery that could affect the salt quality and cavern integrity within the web. This updating of the 1980 report has reexamined the issue of faulting on the west flank; Figure 9 (Cross-section \#3) shows that the previous interpretation of faulting is unnecessary, and any that does occur is probably minor 


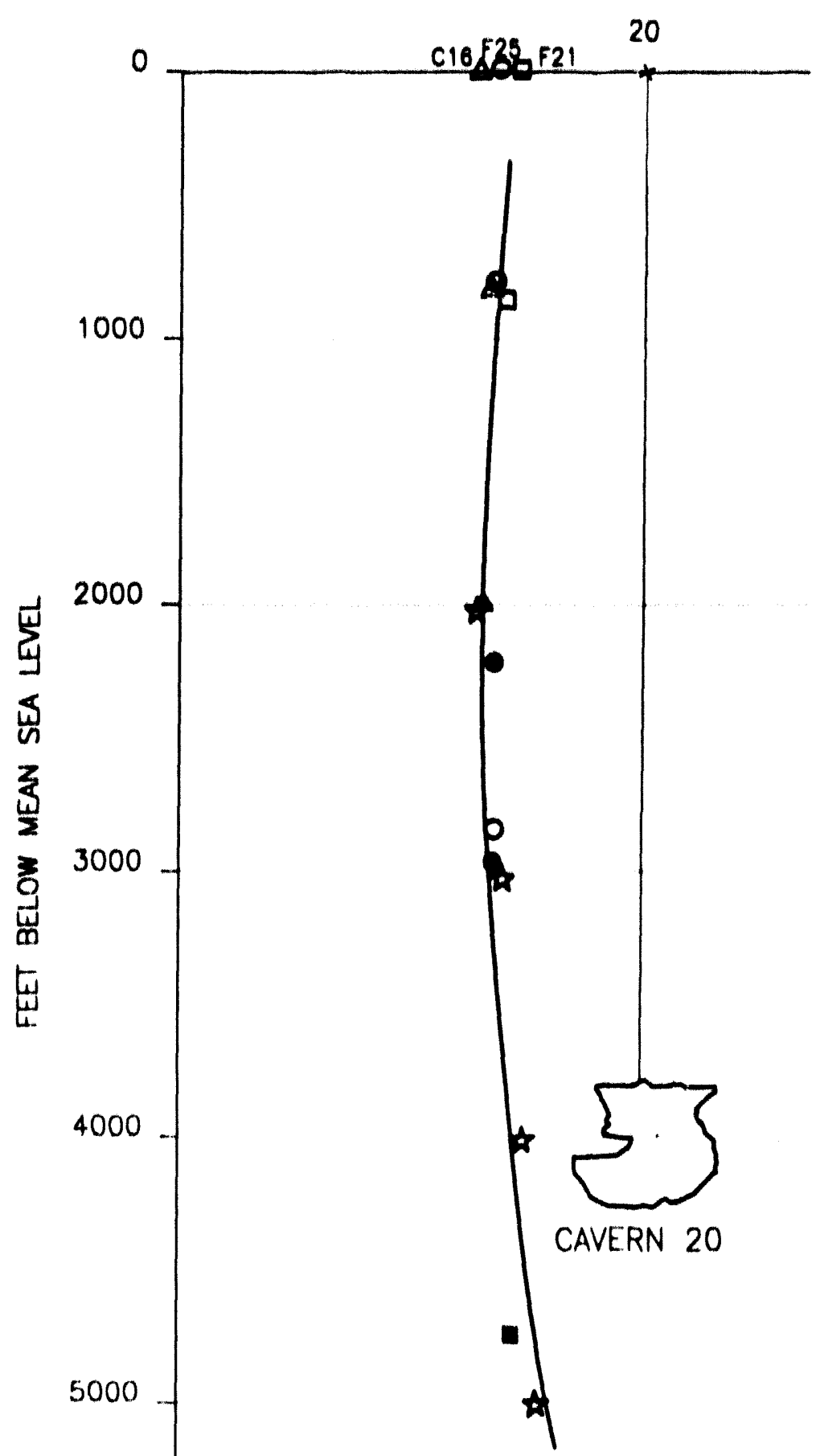

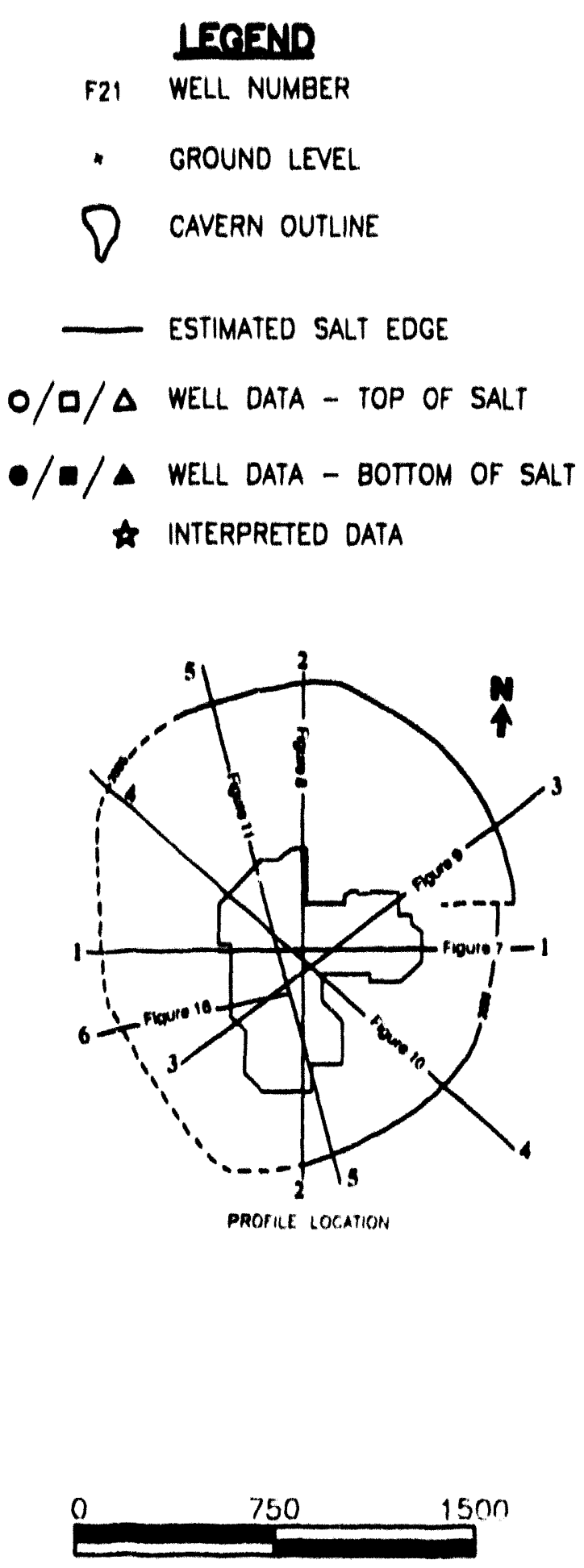

FEEI

FIGURE 16

PROFILE THROUGH CAVERN 20

BAYOU CHOCIAW SPR SIII. 
An unexpected pressure drop of 30 psi was noted on 7 Jun 92 and was similar to a prior drop in 1986. The most plausible explanation for this is a sudden release of gas, similar to gas outbursts in domal salt mines [Thoms and Martinez, 1978]. No other scenarios have been able to account for these anomalous occurrences

Some fresh-water leaching occurred in 1992 and this was projected to have leached some 5. o feet of the web [1,inn, 1992), in some lo.ver portions the amount would likely be greater March 1993 sonar surveying of the bottom portion of the cavern below 4150 At show that new volume was created and some insolubles accumulated at the bottom but the maximum extension at about $41.50 \mathrm{n}$ was not increased This geometry is highly significant at this particular location and for this cavern, as the minimum distance to the edge should not be lessened

Cavern 20 showed excessive gas content had accumulated within the oil in 199.3 Its location at the edge of the dome may influence this since this flank of the dome produces gas from sands against the salt, and which also leaks into water wells The cause of the gas in (avern 20 is speculative, but the exterior location astride an anomalous zone may be conducive to gas penetration

\section{Gas in ()il}

In early 1903 it was learned that a number of caverns within the SPR system had excessive amounts of gaseous hydrocarbons dissolved in the oil the oil would require degassing prior to refining in many cases, and 'ecause the processing rate may be less than drawdown rate criteria, cycling of oil and concomitant degassing is anticipated in order to maintain readiness /O il and Gas Journal, 199.31

In a mumber of instances the gas content had increased, leading to the conclusion that the source could be from within the salt (ias in salt has long been a problem in conventional mining. leading to several fanal accidents following outbursts of gas and associated saltalls /Molinda, 19881 At Bayou Choctaw, (averns 18 and 20 showed higher than allowable gas content in March and May, 1003, and were identilied as requiring treatment prior to drawdown $\wedge$ possible correlation of gassy caverns and the $N 75^{\circ}$ E E trending shear zone shown on figure 6 exists, similar to that occurring al Bryan Mound |Thoms, 109.3) This correlation is similar to that noted by lannacchione ef al $|198+|$ in his study of gas associated with salt outbursts in conventional mining This correlation suggests that gas is able to migrate through these anomalous zones and into the adjacent salt at a faster rate than in normal salt At Bayou Choctaw (averns 18 and 20 are evidently in the salt adjacent to the anomalous zone As noted earlier, Cavern 20 is also located near the edge of the salt and adjacent to gas-producing sands. The rate of increase in gas content in these two caverns is unknown but will be monitored in the future

\section{Subsidence}

Subsidence is of special interest at Bayou Choctaw because of the large number (25) of active and abandoned caverns with substantial total volume $(-160 \mathrm{MMB})$, the generally low site 
elevation (under $10 \mathrm{n} \mathrm{m.s} 1$ ) with associated potential for flooding, and the uncertain (although remote) possibility for collapse of (avern 4, similar to the Cavern 7 incident of 1954

Independent of SPR or other sources of local subsidence, regional subsidence is occurring throughout coastal Louisiana, resulting in some $21017 \mathrm{~mm}(0.007-0.054 \mathrm{ft})$ of lowering each year Several sources contribute to this and have been discussed by Penland et al, (1989) In the Baton Rouge area, including the Bayou Choctaw site, the regional subsidence is at the very low end of the scale, being in the $1.2 \mathrm{~mm} / \mathrm{yr}$ range (Penland et al, 1989, Holdalil and Morrison, 19741 Thus the location further inland at Bayou Choctaw is quite different than all of the other SPR sites, which are nearer the coast and subject to greater sediment compaction and associated subsidence. The regional subsidence value at Bayou Choctaw is not only very small, it is very difficult to measure because of survey accuracy and monument stability problems

The other source of subsidence at Bayou Choctaw which may be involved is that caused by hydrocarbon extraction The amount of production to dute is some $30,000,000 \mathrm{BBB}$., not a large amount as compared with many other domes Presumably this would have little effect directly over the dome, as the production has been around the periphery

The Baton Rouge fault is considered by many to be active, and while it may be moving in geological time. there is no documented evidence of vertical motion in historical time. Nonctheless, in the Baton Rouge area, there is abundant geolngical evidence of its presence Some of the radial faults around the Choctaw dome are considered by Magorian $[1980]$ to be subsidiary to the Baton Rouge fault and are also potentially active As a result, these may influence the local subsidence environment, but given the inconclusive data set, such effects can not be seen at this time Other local subsidence eflects may have been induced previously from injection wells disposing fluids into the caprock, this was thought 10 have caused shifling in the caprock and associated casing failures I/pon cessation of the injection, these problems stopped (Slezak, personal communication, 1988)

Subsidence measurements commenced in 1982 and have been repealed about yearly, initially at some 60 stations, but the number has declined as monuments have been damaged or destroyed The data reveal that there are problems in interpreting trends; reason suggests that some changes are obviously anomalous and inconsistent, and therefore must be looked at with skepticism Based on experience at other SPR siles and storage operations at other domes, there should be an observable and steadily downward trend That is because of steady-state cavern creep closure which is universally present iii all underiguound caverns in salt [Neal, 1991], and seen in laboratory lests and modelling experiments. Some explanations for data inconsistencies have been advanced, but only a few stations have provided steady-state trends and even these data may be suspect A summary of 16 of the less ambiguous survey stations that provide beginning and ending values is shown on Table 4 
TABLE 4 ELEVATION CHANGE AT SELECTEd SUBSIDENCE STATIONS: $1982-93$

\begin{tabular}{|c|c|c|c|c|c|}
\hline$\#$ & Location & $\begin{array}{l}\text { Elevatio } \\
12 / 82^{*}\end{array}$ & $\begin{array}{l}\text { Feet } \\
01 / 93^{+}\end{array}$ & Change & Rate/Yr \\
\hline IB & SE Corner, intake structure & 10.30 & 10.302 & $(0.002)$ & $\ldots . . .$. \\
\hline 2B & SE corner, heliport & 8.62 & 8.56 & 0.06 & 0.0060 \\
\hline $4 \mathrm{C}$ & SE corner, mini leaching pumps & 8.03 & 7.936 & 0.094 & 0.0093 \\
\hline $6 \mathrm{~A}$ & NW corner, security building & 10.78 & 10.582 & 0.198 & 0.0196 \\
\hline 7B & East end, filter pumps & 8.86 & 8.751 & 0.109 & 0.0108 \\
\hline 9 & East edge of well pad 15 & 11.12 & 11.033 & 0.087 & 0.0086 \\
\hline 10B & NW corner of brine pond & 14.64 & 14.378 & 0.262 & 0.0260 \\
\hline IIA & SW corner, maintenance bldg. & 9.06 & 8.915 & 0.145 & 0.0144 \\
\hline 12D & SE corner, control room bldg. & 9.08 & 8.934 & 0.146 & 0.0145 \\
\hline 13B & North edge of brine tanks & 021 & 8.863 & 0.347 & 0.0344 \\
\hline $15 B$ & East edge of pump base & 10.72 & 10.272 & 0.448 & 0.0444 \\
\hline 22B & SW corner of pump base & 10.77 & 10.318 & 0.452 & 0.0448 \\
\hline $3 \mid \mathrm{A}$ & NE corner, well pad 19 & 12.26 & 11.526 & 0.734 & 00728 \\
\hline 32 & NE corner, well pad 19 & 12.30 & 11.737 & 0.563 & 0.0558 \\
\hline $\mathrm{BC} 18$ & "L" flange, cavern 18 & 13.81 & 13.472 & 0.338 & 0.0335 \\
\hline SMS6 & Subsidence monument & 5.17 & 4.550 & 0.620 & 0.0615 \\
\hline
\end{tabular}

The 60 DOE subsidence monuments at Bayou Choctaw are subsiding an average of about $0.03 \mathrm{f} / \mathrm{yr}(9 \mathrm{~mm} / \mathrm{yr})$ over a 121 -month monitoring period, if 11 questionable survey values are excluded. This rejection of values is arguable in that some of the survey values may be correct (many of these are plugged and abandoned wellheads); however, they appear sufficiently spurious with respect to the rest of the site that their inclusion would distort the averages. Including all values yields an average of some $0.050 \mathrm{n} / \mathrm{yr}(15.0 \mathrm{~mm} / \mathrm{yr})$, a departure from the adjusted value, but still overall low subsidence. Even with the larger average, the difference would be only $0.2 \mathrm{ft}$ in ten years. McHenry [personal communication, 1992] believes that site averages here have little meaning, because of the very small values and the accuracy error of the survey (Second Order, First Class standards would allow data scatter of $0.10 \mathrm{f}$ ). However, they do provide a comparison between sites, and show trends that may be correlative with other data.

The average subsidence rate is less than any other SPR site except Bryan Mound (very nearly the same). The only laboratory creep data from Choctaw showed rates nearly as low as the data for Bryan Mound, the lowest of any SPR site [Wawersik and Zeuch, 1984]. This is a possible clue to explain the low amount of observable subsidence. This average rate is consistent with the values that Hoffman et al. calculated for a group array of 19 caverns [Hoffman and Ehgartner, 1993]. The 1971 subsidence values were reported by Allied Chemical to range between 0.01 and $0.02 \mathrm{ft} / \mathrm{yr}$, at a time when the total cavern volume was about $100 \mathrm{MMB}$, substantially less than the 1992 estimate of about $160 \mathrm{MMB}$. Thus, the previously measured values are consistent both with currently measured amounts, and with numerical calculations. 
Nonetheless, the subsidence values measured near Cavern 19 (already surrounded by perennially flooded swamp), are sufficiently high to possibly require long-term mitigation in the form of enhanced diking or localized infilling. At a rate approaching $0.10 \mathrm{ft} / \mathrm{yr}$, the total subsidence in $30 \mathrm{yrs}$ would approach $3.0 \mathrm{f}$. With increased subsidence anticipated from the adjacent UTP Cavern 24 (now containing variable pressure and more compressible natural gas), the combined cavern effects in the adjacent swampland may become more widespread

Cavern 101 is among the deepest in the SPR system, with the bottom at $-4824 \mathrm{f}$. At such depths, creep slosure is predictably greater; consequently, subsidence should be expected to be more in the future around this cavern than at other more shallow caverns [Hoffman, 1992]. The leaching of this cavern was not completed until 1990, as a result very little monitoring data is available. However, measurements between October 1988 and January 1993 show no subsidence, which is difficult to reconcile, because of the theoretical higher rate that should occur at this cavern Longer-term measurements are needed to establish valid trends, both at this and other caverns

January 1993 survey results were examined and showed virtually no change from that acquired in 1988, suggesting there may be difficulties with the datum being used. The datum (DOE 35) elevation used in the 1993 survey was tied to the monument located on the Bayou Plaquemine Railroad trestle when it was first used in October 1988 and subsequent elevations were assumed to be stable. The apparent explanation of the very questionable subsidence history at Bayou Choctaw is that the datum elevation(s) is not accurate. It is reasonable to assume that the 1993 survey is accurate, because of the good data consistency, the results can be adjusted at a future date when the datum is accurately determined and compared with updated First Order Geodetic standards

The relatively small salt mass and steeper sides of the salt stock at Bayou Choctaw (as compared with West Hackberry, for example) may lead to less creep and consequently less vertical subsidence over the top of the dome. A 3-D finite element analysis of an array of seven typical SPR caverns showed that subsidence decreases more than $30 \%$ when the diameter is reduced from I mile to 1/2 mile in the model [Hoffman, 1993]. The details of the seven cavern model in an infinitely large dome are documented in another study [Hoffman and Ehgartner, 1993] that examined the effects of the number of caverns in a field on subsidence. This same phenomenology may occur at Bryan Mound where salt volume relative to cavern void space is similar to Bayou Choctaw, but the average subsidence is also very low as compared with other domes. The paradox at Bryan Mound is that it has largest cavern volume (-250 MMB) and also the lowest subsidence of all the SPR sites.

\section{Flooding}

Periodic and temporary flooding is a fact of life in Iberville Parish, resulting from severe rainstorms, hurricanes, and floodwater backup from the Atchafalaya basin. Overbank flooding from the Mississippi River has not been a problem since 1927 when record floods forced subsequent construction of levees, along with the diversion control measures into the Atchafalaya basin. With major diversion from the Mississippi, the Atchafalaya can backup canal levels to 
nearly $10 \mathrm{ft}$ NGVD (National Geodetic Vertical Datum), higher than many surface elevations on the site. The top of the brine pond embankment is right at $14 \mathrm{ft}$, the highest site elevation, so virtually everything else is under water during extreme flooding events (see Frontispiece).

The humid subtropical climate in Iberville Parish produces an average 59 inches of precipitation annually, which is usually evenly distributed throughout the year, but heavy rains of 1.5 to 4.0 inches can be expected every year and often more than once each year. A rainfall of at least 6.4 inches in a 48-hour period is expected to occur an average of once in two years; 8.0 inches once in 5 years; and 11.5 inches, once in 25 years. The heaviest rains are often associated with tropical storms and hurricanes; Hurricarie Hilda in 1964 caused headwater overflows in the swamp and marshland areas within an elevation range of 5 to $10 \mathrm{ft}$ NGVD, flooding nearly 29 percent of the Parish. Hurricane Carla in 1961, even though centered several hundred miles wcsl, flooded seven percent of the Parish, with local rains of nearly 8 inches in Baton Rouge over a five day period. These statistics serve to expain why flooding is a recurrent theme at this SPR site.

The baseline 100 year flood height is 8.1 A NGVD; the entire dome and area surrounding it are in this zone on the flood insurance rate maps for Iberville Parish, published by the $U$. $S$. Department of Housing and Urban Development [U.S. HUD, 1977]. Because of the environmental reasons enumerated above, water levels sufficient to produce temporary flooding can be expected frequently at the site.

Speculation on increased hurricane frequency was rampant following the summer 1992 occurrence of three major hurricanes affecting the United States and its territories in 19 days. There is lack of agreement on cyclical trends, but there is general agreement that warmer oceans will increase severity of tropical storms, and probably the frequency [Emanuel, 1988]. Thus, understanding of greenhouse warming trends, if it exists, has implications on tropical storm generation, and consequent flooding effects

\section{Seismicity}

In the thirteen years since the previous characterization, a small earthquake of Modified Mercalli Intensity V (MM V) occurred in October 1983 near Lake Charles, about 17 mi north of the West Hackberry facility. The temblor was not felt at all at the SPR site and produced only minor effects at the epicenter, such as cracked plaster and broken dishes [Magorian et al, 1991].

Events such as the Lake Charles earthquake and even stronger (up to $\mathrm{MM} \sim \mathrm{VI}$ ) can occur anywhere along the Gulf Coast, according to most geophysicists. Most likely these events originate in deep basement faults, or in combination with more shallow growth faults. Such a mechanism was postulated for the 19 Oct 30 Donaldsonville earthquake (MM VI.VII), $40 \mathrm{mi}$ southeast of the Bayou Choctaw site. The 1980 report concluded that an event of this magnitude would not produce any significant damage to surface or underground structures even at the epicenter; the Lake Charles event near West Hackberry supports this prediction for Bayou Choctaw, even though the latter event was slightly smaller. 
A further evaluation of the ground motion effects at Bayou Choctaw from a New Madrid (1811-12) event with Richter Magnitude 8+ concluded there would be less peak horizontal acceleration than from a repeat Donaldsonville event at the epicenter. The latest earthquake maps for the United States show that for Bayou Choctaw, with a $90 \%$ probability of non-exceedance in $250 \mathrm{yrs}$, the mean horizontal acceleration in rock is $0.03 \mathrm{G}$ [Algermissen, et al.] Thus seismicity is not a factor of geotechnical risk at Bayou Choctaw.

\section{Environmental Considerations}

Bayou Choctaw is the only SPR site located in an alluvial environment, at the edge of the Mississippi River levee and the Atchafalaya backswamp, rendering it vulnerable to flooding from those sources. Flooding considerations were discussed in an earlier section.

The extensive diversions and control structures added elsewhere to protect populated areas have made water levels at the site particularly uncertain. The original cypress backswamp was clearcut long before SPR, so that today the environmental classification of this wetland/industrial area is naturally confusing.

Natural gas seeps occur along the dome edges, as at many other domes, but to date no adverse effects on any of the caverns have been observed, such as gas leaking into the caverns. As discussed earlier, Caverns 17 and 20 have higher than desired gas contents, but this does not appear to be related to these gas seeps. The possibility of either natural or stored product gas communicating through caprock voids has been expressed, but this has not been detected anywhere.

\section{Expansion Possibilities}

Bayou Choctaw has distinct location advantages near distribution points; consequently the question of additional cavern space has arisen periodically. A cursory glance at the salt map (Figure 6) shows that nearly all of the space has been used, so at this point the siting of more caverns may be analogous to "shoehorning." Further, the placement of additional caverns puts them ever closer to the dome edge, which experience shows to be at greater risk than interior locations. This is because salt conditions at the dome edge deteriorate rapidly at the contact with the exterior sediments. Problem caverns at other domes have often been situated at boundary conditions near dome edges, or near contacts with anomalous zones [Neal, et al., 1993]. In event that any additional cavern development were pursued, it would be necessary to institute highly controlled leach procedures, with more-than-normal monitoring.

Notwithstanding the above disadvantages, the possible locations $A$ and $D$ marked on Figure 1 were identified in the 1980 report for possible SPR expansion. However, they could only be considered viable options after essential exploration is accomplished to verify the precise geometry and salt web thickness between the caverns and the edge of dome. The location (D) north of abandoned Cavern 13 (Figure 11, Section 5) was considered potencially suitable for a 
10 million barrel cavern, and that judgment has not changed. The buffer distance between this potential cavern and the dome edge would be approximately $500 \mathrm{ft}$. It was noted in the 1980 report that this area of the dome has experienced extensive pressure leakage of caverns, as shown by the relatively large number (9) that have been abandoned or collapsed (Cavern 7). This possibly is related to faulting in the caprock which affected well casings, but it may also be due to the rather shallow depth of these caverns and minimal salt roof thicknesses. Because of these reasons and others stated earlier, this location along the dome periphery would need to receive more complete geotechnical evaluation than usual, with special attention given to salt quality, etc. Also, collapsed Cavern 7 and Cavern Lake are less than $1000 \mathrm{ft}$ away, but the effects from them would be limited to depths above $1500 \mathrm{ft}$. There should be minimal influence on deeper caverns with tops at $2000 \mathrm{ft}$ and more.

Locations B and C, which had been identified in the 1980 report, were subsequently developed as Caverns 101 and 102, respectively. The former was moved outboard slightly, to stay away from the zone of influence around Cavern 4 , in event it experienced failure similar to Cavern 7.

A potential location on an azimuth of $115^{\circ}$ ESE of Cavern 19 would initially be some $400 \mathrm{ft}$ from the dome edge, and about the same distance from both SPR Cavern 19 and UTP Cavern 25. These distances are less than the SPR Phase III criteria; therefore this location is marginally unacceptable for SPR use. However, this limitation may not apply to other applications involving smaller diameter caverns, etc. Another approach to gain additional storage volume in this portion of the dome would be to simply enlarge Cavern 19; the current volume is about 12.2 million barrels, and this could probably be enlarged by $50 \%$.

The location west and south of Cavern 19 had similarly been discussed in the 1980 report (location A) as being potentially suitable, but the same limitations apply to it as the location discussed above. The 1980 report concluded that this location is marginal for cavern development. A vertical seismic profile could validate this location.

There is a small but unlikely possibility that an additional cavern could be constructed immediately west and below abandoned Cavern 10. The principal uncertainty is in the shape of the salt overhang here and a VSP survey would be needed to determine the geometry and thickness of the buffer between the dome edge and cavern. Such practices amount to "shoehorning" and should only be attempted when other storage is not available. An exterior cavern location here would have pitfalls similar to those noted above. There is much uncertainty in the west overhang and our dome mapping suggests this location would be unsuccessful.

Mills (1993) points out that Cavern 20 could be enlarged above its present configuration, as the depth now ranges from 3830 to $4246 \mathrm{ft}$ (Fig. 9). This option would create a cylindrical space above the current storage, possibly to a depth of $\sim 2500 \mathrm{ft}$, which would be about 6 million barrels of new space. This location at the edge of the salt stock has inherent limitations as noted previously. This cavern was also noted in 1993 to have absorbed more gas into the oil than allowable, and degassing measures were being planned. Cavern 20 in its current configuration is already closer to the edge of salt than desirable, and effectively limits oil drawdowns to one or 
two cycles. While this option is physically possible, the potential difficulties would seem to outweigh any advantages.

Another possibility suggested by Mills (1993) would place a new cavern between and below abandoned Caverns 2 and 3. To maintain adequate separation from Caverns 15 and 102, this location would have to be very close to Cavern 3, possibly compromising recommended standoff distances. Section 2 (Fig. 8) shows this concept is possible and suggests it may be worth further consideration if more storage space is needed. Nonetheless, it would be a very tight fit, as with all the other locations discussed above.

Assuming location D is suitable and Cavern 19 were enlarged slightly, the existing SPR capacity conceivably could be expanded by about 15 million barrels. Other options are less promising and would require more study.

\section{SUMMARY OF SIGNIFICANT FEATURES AFFECTING SPR}

The Bayou Choctaw salt mass appears to be comprised of at least two lobes that are separated by a major fault transecting the entire dome and which joins the regional fault system. This fault displaces the caprock to some extent and has apparently influenced several solution caverns, most noticeably in elongating Caverns 4 and 1 (abandoned). It does not seem to have affected the integrity of any operational caverns, but may have contributed to earlier unstable caprock. Smaller radial faults related to the piercement process in the rising salt mass have been omitted from the new maps for reasons of simplification; further, they have no bearing on integrity and safety of the storage operations.

Subsidence over the 160 million-barrel (total) cavern field is lowering the surface less than an inch per year, a rate lower than other SPR sites except Bryan Mound, but the 10-foot surface elevation requires continuing surveillance for flood protection. As this dome is near capacity, the rate of subsidence is not apt to increase much, unless volume is expanded as a result of drawdown of SPR oil, etc.

There is room for only a few more caverns on this dome, and several existing ones could be enlarged slightly. At this time, SPR had no plans for enlargement of their storage volume, and Union Texas Petroleum was considering one additional cavern. The co-use of this dome for storage of crude oil and hydrocarbon products has continued safely for nearly fifteen years, in large part because good communication exists between operators.

Cavern 4 has similar features to collapsed Cavern 7, and concern was expressed earlier that continuing erosion of the caprock could lead to failure, resulting in another collapse crater and lake around the cavern. A reexamination of the cavern dimensions in an August 1992 sonar profile showed virtually no change since 1980 and provides confidence in the continuing stability. Reevaluation of this cavern environment is recommended every five years. 
Cavern 20 has the thinnest salt web between the cavern and the outside of the dome of any SPR cavern and is limited to a single raw water drawdown. Special procedures can extend the operational life of this cavern if only the upper reaches of the cavern are used, or if saturated brine is used in displacing the oil. The latter option is not available for offsite drawdown at this time because of limited brine pond capacity, but a dedicated brine cavern could be a possibility for product cycling. Other alternatives could also be developed, using other caverns in combination.

Cavern 15 and 17 are adjacent and separated by a web which may be a small as 100 feet at closest approach. The caverns are now operated at essentially equal pressure, as earlier integrity testing showed that pressure communication may have occurred. In the event of drawdown and additional leaching, the caverns will eventually coalesce and become one very large cavern. The thin web does not present any special operating difficulty when operating as an effective gallery. The larger-diameter Cavern 15 was predicted to dominate the stability of the web when the caverns are operated at a differential pressure. When operating under a differential pressure, it is more important to maintain pressure in Cavern 15 than it is in Cavern 17.

Eleven injection wells are used for brine disposal, but are limited to about 100,000 barrels per day total. This is substantially less than desired and one third the predicted capacity. Operating problems have led to very sluggish yields and have required very expensive cartridge filtering. The wells could be recompleted in the Lafayette gravels without screens and should achieve much higher injectivity values.

Temporary flooding is a fact of life in Iberville Parish, owing to normal cylclonic storms and periodic severe thunderstorms. Continuing subsidence may exacerbate already unfavorable conditions in low-lying areas; diking and road heightening is the only recourse.

\section{ACKNOWLEDGMENTS}

We are grateful to Bob Haley, Union Texas Petroleum, who was generous in sharing his time and information on Bayou Choctaw. We also thank Ken Mills and Matt Slezak of DynMcDermott Petroleum Operations Company, for reviewing the report and especially for sharing their ideas about the site. Brian Ehgartner and Jim Todd provided peer review and their helpful suggestions are appreciated. 


\section{REFERENCES}

Algermissen, S. T., D. M. Perkins, P. C. Thenhaus, S. L. Hanson, and B. L. Bender (1990) Probabilistic Earthquake Acceleration and Velocity Maps for the United States and Puerto Rico. U. S. Geol. Surv. Map MF-2120.

BPS (1992, 1993) Annual Subsidence Report, SPR, Fiscal Year 1992. Pub. No. D506-0316509, Oct. 1992, Boeing Petroleum Services, New Orleans. 1993 data from Bayou Choctaw obtained from $\mathrm{J}$. McHenry and discussed informally.

Ehgartner, B. L. (1993) Bayou Choctaw Caverns 15 and 17 Web Analysis. Sandia National Laboratories Report SAND92-2890, ALbuquerque, NM. 1992.

Ehgartner, B. L. (1993) Personal Commumication, Sandia National Laboratories, Department 6113, Albuquerque, NM.

Goin, K. L. and D. K. Buchanan (1986) Letter to DOE SPR PMO from Sandia National Laboratories dtd 20 Feb 86, Subject: Documentation of Results of Brine Pressure Test of Bayou Choctaw Cavern 17.

Goin, K. L. and J. T. Neal (1988) Analysis of Surface Subsidenice of the Strategic Petroleum Reserve Crude Oil Storage Sites From December 1982 to January 1988. Sandia Nat'l Labs. Report SAND88-1309, Albuquerque, NM.

Heffelfinger, G. S. (1991) Creep Closure of Salt Caverns in the U.S.DOE Strategic Petroleum Reserve. Sandia Nat'I. Labs. Report SAND90-2614. Albuquerque, NM.

Hoffman, E. L. (1992) Effects of Cavern Depth on Surface Subsidence and Storage Loss of Oil-Filled Caverns. Sandia Nat'l. Labs. Report SAND92-0053, Albuquerque, NM.

Hoffman, E. L. and B. L. Ehgartner (1993) Effect of the Number of Caverns on Storage Loss and Subsidence of Oil Filled Caverns. U. S. National Rock Mechanics Symposium, Madison, WI, June 1993.

Hofrman, E. L. (1993) Personal communication: results of preliminary calculations. Sandia Nat'l. Labs., Albuquerque, Dept. 1561.

Hogan, R. G. et al. (1980) Strategic Petroleum Reserve (SPR), Geologic Site Characterization Report, Bayou Choctaw Salt Dome. Sandia National Laboratories Rept. SAND80-7140.

Holdahl, S. R., and N. R. Morrison (1974) Regional Investigations of Vertical Crustal Movements in the U. S. Using Precise Relevelings and Mareograph Data. in Recent Crustal Movements and Associated Seismic and Volcanic Activity: Tectonophysics, Vol. 23, P. 373-90. 
Iannacchione, A. T. et al. (1984) Assessment of Methane Hazards in an Anomalous Zone of a Gulf Coast Salt Dome. U. S. Bur. Mines Report of Investigations No. RI-8861.

Kupfer, D. H. (1980) Problems Associated with Anomalous Zones in Louisiana Salt Stocks, USA. 5th Intl. Sympos. on Salt, Hamburg, Germany, 1978; N. Ohio Geol. Soc., Cleveland; V. 1, p. $119-134$.

Kupfer, D. H. (1990) Anomalous Features in the Five Islands Salt Stocks, Louisiana. Trans. Gulf Coast Assoc. of Geol. Societies, V. 40, p. 425-436.

Linn, J. K. (1992) Analysis of BC-20 Pressure Drop on 7 June 1992. Sandia National Laboratories Memo to DOE, New Orleans SPR Proj. Mgt. Office, 15 June 92.

Magorian, T. R. et al. (1991) Strategic Petroleum Reserve (SPR), Additional Geologic Site Characterization Studies, West Hackberry Salt Dome, Louisiana. SAND90-0224; Sandia Nat'l. Labs., Albuquerque, NM.

Mills, K. E. (1993) DynMcDermott Petroleum Operations Company, New Orleans, LA; Personal communication.

Molinda, G. M. (1988) Investigation of Methane Occurrence and Outbursts in the Cote Blanche Domal Salt Mine, Louisiana. U. S. Bur. Mines Report of Invest. RI-9186, Pittsburgh.

Munson, D. E., A. F. Fossum, and P. E. Senseny (1989) Approach to First Principles Model Prediction of Measures WIPP in Situ Room Closure in Salt. SAND88-2535; Sandia Nat'l. Labs.; Albuquerque, NM.

Neal, J. T. (1991) Prediction of Subsidence Resulting from Creep Closure of Solution-Mined Caverns in Salt Domes. Proc. 4th Int'l. Symp. on Land Subsidence. Int'l. Assoc. Sci. Hydrology, IAHS Pub. no. 200, p. 225-234.

Neal, J. T., T. R. Magorian, R. L. Thoms, W. J. Autin, and R. P. McCulloh (1993) Anomalous Zones in Gulf Coast Salt Domes with Special Reference to Big Hill, TX, and Weeks Island, LA. Sandia Nat'l Labs. Report SAND92-2283, Albuquerque, NM.

Nye, J. F. (1979) Memo from Sandia National Laboraties to R. W. Mazurkiewicz, DOE APR PMO, 27 Nov 79, Subject: Cavern 15-17 Depressurization.

Oil and Gas Journal (1993) DOE to Degassify 200 Million Barrels of SPR Crude. 3 May 93, p. 130.

PB-KBB, Inc. (1978) Salt Dome Geology and Cavern Stability Analysis, Bayou Choctaw, Louisiana. Prepared for US Dept. of Energy, Strategic Petroleum Reserve, New Orleans. 
PB-KBB, Inc. (1989) Long Term Requirements for Brine Disposal; Bayou Choctaw SPR, Iberville Parish, Louisiana. Prepared for Boeing Petroleum Services, New Orleans.

PB-KBB, Inc. (1991) Rock Mechanics Analysis, Bayou Choctaw Salt Dome, Iberville Parish, LA. Unpublished report prepared for Union Texas Petroleum by PB-KBB, Houston, TX.

Penland, Shea et al. (1989) Relative Sea Level Rise and Subsidence in Louisiana and the Gulf of Mexico. Coastal Geology Technical Report No. 3, Louisiana Geological Survey, Baton Rouge.

PGA and Associates (1978) Commercially available microgravity survey.

Slezak, M. (1988-1992) Personal Communication, Boeing Petroleum Services, Bayou Choctaw, LA.

Thoms, R. L. and J. D. Martinez (1978) Blowouts in Domal Salt. 5th Symp. on Salt, Hamburg, Germany. N. Ohio Geol. Soc., Inc., Cleveland.

Thoms, R. L. (1993) Effects of Anomalous Features (AFs) on Solution Mining of Storage Caverns in Domal Salt; p. $41-53$ in Neal et al., op. cit.

Todd, J. L. and K. H. Smith (1984) Collapse Warning System for Bayou Choctaw Cavern 4. Sandia Nat'I. Labs Report SAND88-1510; Albuq., NM.

Todd, J. L. (1992) Internal memorandum dated 11 Aug 92, Sandia Nat'l. Labs. Dept. 6113. Albuquerque, NM.

U. S. Department of Housing and Urban Development (1977) Flood Insurance Study, Iberville Parish Louisiana (Unincorporated Areas). (1988) Flood Insurance Rate Map, Community Panel Number 2200830004 B, effective 1 June 1978.

Wawersik, W. R. and D. H. Zeuch (1984) Creep and Creep Modeling of Three Domal Salts -A Comprehensive Update. Sandia National Laboratories Report SAND84-0568. Albuquerque, N.M 


\section{APPENDICES}

A Bayou Choctaw Regional Geologic History

B Index of Bayou Choctaw Well Data Used in Construction of Contour Maps and Sections

C Bayou Choctaw Cavern 4 -- Comparison of 1992, 1980, and 1963

Cavern Sonars. J. L. Todd Memo, Sandia National Laboratories

D Computer Generated Graphical Representation of Cavern 101, Bayou Choctaw 


\section{APPENDIX A \\ Bayou Choctaw Reglonal Geologic H1story \\ Introduction}

This overview is intended for those readers desiring general Information, and for those with $1 \mathrm{imlted}$ background in the geosclences. It is not detalled and is uneven in presentation by design. The reader who destres inore complete information should refer to the original characterization report (Ref. 1, main report), or to more recent general references on Gulf Const geology and tectonics [Ref. A-1].

\section{Paleozolc Era (570-245 my)}

Pangaea ("all lands"), the single protocontinent that drifted together at the end of the paleozolc, resulted in a huge mountain mass, probably somewhat $11 \mathrm{ke}$ the Himalayas today. It lay to the not (relative to today), Including the center of north America, and is thought to have been glaclated perlodically, tylng up much ocean water in icefields. No rocks of Paleozolc age are expected to underlle the site.

\section{Mesozole Era (245-66 iny)}

The welght of this crustal mass (or possibly a huge astrobleme collision) melted the underlying mantle so that ti broke apart, forming volcanle rifts and creating new ocean floor, simllar to the African rift valleys and Red Sea today. The Gulf Coast Geosyncline was one of a string of rift basins created by the opening of the Atlantlc in the breakup of Pangaea, This drifting apart of the present continents occurs at a more or less steady rate, as it has since the end of the Paleozolic.

Triassic Perlod: The inftal deposits underlylng the salt are oceanfe basalts and red beds of Trlasslc age, called Eagle Mills in the culf Coast (Newark Series where better exposed on the East Coast). These deposits may extend out onto the new oceanic crust underlying the site.

Jurassic Perlod: The overlylng redbeds of early Jurasslc age are called Norphlet in the Gulf Coast. The original depositional basin of the Jurassle Louann salt and evaporites was one of the string of $r i f t$ basins, similar to some evaporite basins in East Africa today.

The anhydrite overlying the Louann salt is called Buckner and the overlying dolomite is known as Smackover, the Gulf Coast correlative of the Arab limestone pay of the Persian Gulf, the most oll-productive horizon in the world. The remainder of the overlying Jurassic consists of a thick sequence of Cotton Valley limestone and bituminous shale. Although the salt in the Bayou Choctaw dome is of Jurassic age, it may have been deposited to the north so that only oceanic basalts of this age or even younger were ever deposited here. 
The salt from which the Bayou Choctaw salt dome formed is probably not In its original depositional position. It appears to have migrated southward and upward as a sl11 through the sediments descrlbed above or outside, seaward of the thlck sediment wedge at a depth of two or three to six or seven miles. Thls sill is belleved to be exposed at the toe of the sediment plle on the floor of the Slgsbee Deep (a trough in the Gulf of Mextco) today.

Cont Inental rafting, and seafloor spreading have revolutionlzed the concept of the origin of basing like the Gulf Coast Geosyncilne; this concept of deep horlzontal salt inlgration and intrusion is one of the inost Innovative and Important Ideas today affecting hydrocarbon exploration.

Cretaceous Perlod: The updlp Cretaceous sequence of Hosston clastics and limes, Sligo oolltes, PIne Island shale, James lime reef and ferry lake anhydrite, Glen Rose limes is overlaln unconformably by the upper chalk section: Austin, Ozan or Annona, and Nacatoch or Arkadelphia with intervenlng Blossom or Toklo sands and thick shales. The shallow-water reef carbonates are equlvalent to baslnal shales to the south whlch may underlle Bayou Choctaw.

The sands on the imlddle Cretaceous unconformlty produce gas In the deep Tuscaloosa trend Just north of the Baton Rouge fault and Bayou Choctaw, at a depth of greater than flve mlles. Metamorphlsm in these thlek Appalachlan-source baslnal sediments is so extensive that the clean sands have been converted to tght quartzlte whlle the orfglnally. shaly or dirty sands have retalned some gas-fllled porosity as the clay inlnerals have been metamorphosed to chlorite mlca schlst. At thls depth, production is only economle on four square-mlle unlts so that geologic features the slae of Bayou Choctaw dome can be completely inlssed.

The chalk probably underlies the site in normal position, and may underlle the salt sill and thereby contaln produclblle oll and gas -. whlch DOE has acquired along with the salt.

Conozols Era $(66-2$ my)

Tertlary Perlod: The downdlp surface section of the Gulf coast proper in Loulslana and Texas is a thick plle of Tertlary sands and shales, correlative with the carbonates of Florlda and the Bahamas. All of these deposits face the active east-west tectonic zone running from the Mexican volcanoes through the greater Antilles from Cuba to the VIrgin Islands. The ocean floor here was welded in place by the end of the Cretaceous, so that a full, norinal Tertlary section underlles the site.

Paleocene Epoch: The Tertlary sequence of the Gulf Coast starts with Midway shale, a normal marine deposit which preceeds the Laramide orogeny, the plate collision whlch created the Rocky Mountalns and flooded the Gulf with coarse clastlc debris. 
Eecene Epochi: These are the oldest sediments deposited in the culf Coast delta sequence. As sediments accumulate on the north shore of the culf of Mexico, the older sediments are depressed and compacted, Increasing their dip toward the Gulf. Ultimately, a thlck sedlmentary section accumulates on the edge of the continent, often referred to as a geosyncline. This simple reglonal pleture is complicated by the Instabllity of the underlying salt which forms domes and other features such as ridges and squeeze-ups.

Wllcox deltalc deposits as much as a mlle thlck, Including conl measures which have been penetrated in central Loulslana and adfolntug southwestern Mississlppl, 40 mlles north, represent the laramide deposits. These are overlaln by downdlp Yegua shales whlch in turn are overlaln by Jackson shale. None of these deposits have been penetrated yet at Bayou Choctaw.

Qlfrocene Eoochi The lowermost 011 gocene Vlcksburg shale is overlaln by the deepest sediments penetrated in the vicinlty of the dome, the deepwater shales of the Nodosarla Embayment, the oldest and most northeasterly of a sorles of Frlo depresslons. These shales are overpressurred desplte a serles of deltate sands: Nodosarla at least n thousand feet above the base of the shale, followed locally by Bollvina mexlcana. Above thls sand sequence $1 \mathrm{~s}$ the Pontlo deepwater facles undor the Marginulina texana sands, the eastern equlvalent of the Hackberty facles. This 1 s the doopest horlzon whlch is penetrated In onough wolls: to map the domal structure (Flgure 6, maln report), Table 1 , the stratigraphle correlation chart, Ifsts the minclpal stratlgraphlo linelzons Important to the geological interpretation.

The upper Frlo is a shallow-water sand and shale section topped by the Anahuac shale, the uppermost seallng horlzon agalnst the sall (Flgure 3, matn report) above the Marglnulina howell sand, capped by the Heterostegina reef (Flgure 4). The reef is a rlug of coral as much as 400 feet thlck bullt up around the domw, It is used for toxlc waste. disposal in the vicintey. Bayou Blue dome to the west has a Heterosteglina atoll three times as thlck wlth lost clrculation requlring: extra strings of casing to reach the 011 and gas pays.

Mlocene Epochi The outar edge of the shelf grew southward past Bayou Choctawest in lower Mlocene time, so that the atoll is overlaln by a sand plle. Thts sand plle being dumped off the south edge of the North American cont lnent at least since the Mlocene has deformed the underlying Jurassic salt into ridges and domes of which west Hackberry Is one of the largest and Bayou Choctaw one of the smallest. Dips in these sands are llimled to 35 degrees, even agalnst the near-vertical salt face, except possibly at the west end of the dome. The base of the sand plle is paleontologically marked by the dlsappearance of Discorbls "restricted," the last far-offshore deposit in the stratigraphic sequence. The rest of the lower Mlocene is represented by thlck alluvlal sands. The lower part has marlne shale breaks including Siphonina davisi, correlated on some logs. 
Undt

Holooene: Rrimt ine allusium

Pleiatocene

wisconein

Alton/POortant rrmirim.

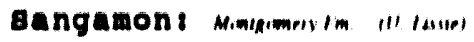
I11 inolan

Yarmouthiant Amin Im d luive

Kanean

Aetondant Williana im

Nobrabkan

Lefayettes iminrlir Im

Pl locone

Mlooene

Upper

Bigenorina floridana

bigenorina nodosaria

Taxtularia stappori

Mlddle

bijonerina humblei

Cristollaria

ciblcides carstensi opima

Amphistogina

lower

Robulus

operculinoldos

cibicidos

Marginulina asconsionensis

Siphonina davisi

- - UNCONFORMIT X -

Anahuac (Discorbis "rostrictod") DR ollgocene

llotarostagina

Margimulina howel

Frio

Miogypsinoldos

Cibicides hazaardi

Marginulina texana

Pontic facles

Bolivina mexicana

Nodosaria blanpodi
SYmbol

\section{a}

8

(p)

$\mathrm{ka} / \mathrm{ks}$

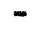

ne

Pl,

MI

A (si)

B (52)

L. (53)

2

W

BH (S4)

CI

CO $(55)$

$A B$

RL. (S6)

op

$\mathrm{CA}(5 \%)$

MA ( 98$)$

S1) (59)

H

MH

$F$

MG

$\mathrm{CH}$

MT

BM

NB
Lithelogy

peat, muck mud

and and gravel

mud

sand and gravel

mud

sand and gravel

mud

sand and gravel

gravel

sit, mud, and sand

mud \& sand

sand and gravol

mud

gand and gravel

mud

marine sand

doltalc sand

mud

deltalc sand

mud

unconf ormity

shale

thin sands

sand

shale

marine sand

sand and shale

sand

shale

thin sand

shate

coral atoll

sand

shalo

sands

thick sand

marlne sands

thin sands

near qeopressure

thin oll-bearing sands

II 
The middle Mlocene is represented by the last marine shale breaks, particularly those containing the Amphistegina B fauna with volcanlc ash from the Mexican orogeny. This is the shallowest paleontologic data polnt avallable around the dome. Table 1, the stratigraphic correlation chart, shows younger zones by their standard paleontological name, even thougit the marker microfossil is not found in the non-marine sediment at Bayou Choctaw. These unlts have been correlated around the dome but have no other recognized name.

The upper Mlocene alluvial sands are are all stacked polnt bars deposited by the ancestral Misslsslppl, separated by sllts. These thlck, permeable sands are only partially minerallzed close to the salt face. They do not represent a threat for oll leakage from the caverns whlch are not leached close to the edge of the salt.

Elecene Eposhi The alluvial section contlnues through the pllocene, with slightly mole backswamp sllt. The basal unlt is a thick gravel correspondlng to the Gollad of Texas. The apparent unconformfty below this gravel is eroded deeply finto the Mlocene close to the dome, Indicating the dome had extenslve surface expression during this onshore alluvial deposition.

Qunternary Period: Plelstocene Epoch:

The basal pre-glaclal unconsolldated Lafayette gravel (Cltronelle Fin.) erodes linto the underlyling pllocene. The overlylng sedimonts were deposited during and after each of the glaclatlons of the continent to the north, when sea level was as much as $450 \mathrm{ft}$ lower than today, and in the followlng interglacial stages as the sea returned to near its present level. Thus the basal sand of each sedimentary sequence, outwash brought down to the Gulf, is correlated with the giactal stage and the overlying mud with the following interglaclal. Some or all of the glaclal stage is actually represented by the basal unconformity below each channel sand [Ref. A-2]. These sediments are occasionally called willis in thls part of the ciulf const.

Nebraskan Stage: The oldest glacial sequence is Nebraskan, found at the top of or Just above the Lafayette gravel. The overlying Aftonlan mud contains a distinctive volcanle ash marker 1 lke those of the iniddle Mlocene, which has been tied to the volcanic or orogenic theory of glaclation.

Kansan Stage: The Kansan, where marine, is the Lenticullna sand, at a depth of some $1350 \mathrm{ft}$ on the flanks of the dome. The Yarmouth (lower Lissie) or Angulogenerina clay, which ropresents the long interglacial Interval in the middle of the plelstocene, is at a depth of $1100 \mathrm{ft}$ on the flanks of the dome. It contains the uppermost glauconite marker in the sedimentary section, indicative along with the microfauna, of the most recent open marine sedimentation.

Illinolan Stage: Montgomery (Upper Lissle) or Trimosina sands, at 
some $900 \mathrm{ft}$ depth, were deposited during the following glaclation. Sangamon clay was deposited during the following interglaclal interval.

W1sconsin Stage: The Pralrie outwash sands of which the basal Alton (Beaumont "B"), at a depth of $200 \mathrm{ft}$ on top of the dome and $400 \mathrm{ft}$ on the flanks, is the thlckest and most massive, having been correlated over almost every onshore salt dome. At the surface to the north, they make up the plain whlch runs from Beaumont through Lake Charles to Lafayette.

The sands were formed at the lower sea level whlch occurred when the continental lcecap extended to the Ohlo and Missourl Rivers, the main sediment sources for the Misslssippl and the Gulf Coast. Most of thom are thick alluvial polnt bars with basal gravels, although there is some beach sand in the sequence. More than $1600 \mathrm{ft}$ of them are found in the canyon cut through Timballer Bay fust west of the Lafourche Delta.

These unconsolidated sediments are found across the top of the dome, uplifted but not fully breached by the salt intrustion and 1 ts overlying residual caprock. The active faults inherent in the caprock extend upward as the salt continues to intrude, deforing these overlying sediments, all the way to the surface.

Holocene Stage: The Plelstocene sands are overlain by Atchafalaya muck (four deltas) deposited in the last 5000 yrs, during which time sea level rose some $450 \mathrm{ft}$ as the earth's continental icecaps melted, leaving only the lce cover in Greenland and Antarctica. This was deposited in the swamp as a, highly-organle black gumbo or inclplent coal. Water content in these unconsolldated sediments is still as high as 708 .

The active shallow fault orlginating In the caprock and salt shear zones have only displaced the Holocene sediments a few feet. They do not pose any apparent $r l s k$ to the storage caverns by themselves, but subsidence along them could concelvably dannge surface facllitles and well casings, as has occurred at other domes used for storage of l.PG products, e. g., Stratton RIdge. TX.

\section{References to Appendix A}

(1) Worrall, D. M. and S. Snelson (1989) Evolution of the Northern Gulf of Mexico, with Emphasis on Cenozolc Growth Faulting and the Role of Salt. Chapt. 7, In The Geology of North Amerlca. An Overvlew: Geol. Soc. Amer., Boulder, Co, p. 97.138.

(2) Bernard, H. A. and R. J. Leblanc (1965) Resune of the Quaternary Geology of the Northwestern Gulf of Mexico Province. In The Quaternar; of the United States; Princeton Univ. Press, Princeton, NJ, p. 137-186.

[3] Ginn, R. (1991) Personal communication, and fallure report of oxy Chem. Inc., Rallroad Commission of Texas, Austir, TX. 


\begin{abstract}
APPENDIX B
INDEX OF BAYOU CHOCTAW WELL DATA USED IN CONSTRUCTION OF CONTOUR MAPS AND SECTIONS
\end{abstract}

PART 1, p. B-2 thru B-4: listing of individual wells, identification number (on Figure 1, well location map), and ownership

PAR Г 2, p. B-5 thru B-17: listing of stratigraphic marker horizons by depth, as determined from well logs

NOTE: stratigraphic correlation symbols are summarized on Table 1, p. A-4, Appendix A

B-1 
BAYOU CHOCTAW SALT DOME PROJECT

\begin{tabular}{|c|c|}
\hline Acres \# & Well Identification \\
\hline 2801 & BA 1 \\
\hline 2802 & BA B-1 \\
\hline 2803 & $B A C-1$ \\
\hline 2804 & BA D-1 \\
\hline 2805 & BE 2 \\
\hline 2806 & Penton 1 \\
\hline 2807 & Roussel 1 \\
\hline 2808 & BA 1 \\
\hline 2809 & BA 2 \\
\hline 2810 & BA 3 \\
\hline $281 !$ & BA 4 \\
\hline 2812 & BA 5 \\
\hline 2813 & BA 6 \\
\hline 2814 & BA 7 \\
\hline 2815 & BA 8 \\
\hline 2816 & BA B-1 \\
\hline 2817 & BA B-2 \\
\hline 2818 & BE 9 \\
\hline 2819 & BE 10 \\
\hline 2820 & BE 11 \\
\hline 2822 & BE 12 \\
\hline 2824 & C 2 \\
\hline 2825 & C 3 \\
\hline 2827 & C 4 \\
\hline 2901 & C 1 \\
\hline 2902 & BA 1 \\
\hline 2904 & BA A-2 \\
\hline 2907 & BA A-3 \\
\hline 2908 & $B A C-1$ \\
\hline 2909 & BE 1 \\
\hline 2910 & BE A-4 \\
\hline 2911 & LC 1 \\
\hline 2912 & LC 2 \\
\hline 2913 & LC 3 \\
\hline 2914 & LC 4 \\
\hline 2915 & LC 5 \\
\hline 2916 & LC 6 \\
\hline 2917 & Strata 1 \\
\hline 4400 & $\mathrm{C}_{1}$ \\
\hline 4401 & C 2 \\
\hline 4402 & C 3 \\
\hline 4403 & C 4 \\
\hline 4404 & C 5 \\
\hline 4405 & C 6 \\
\hline 4406 & C 7 \\
\hline 4407 & C 8 \\
\hline 4411 & $\begin{array}{l}\text { C } 10 \\
\text { C } 19\end{array}$ \\
\hline 4414 & C 19 \\
\hline
\end{tabular}

Owner
Levert Heirs
Levert Heirs
Levert Heirs
Levert Heirs
Levert Heirs
Levert Heirs
Levert Heirs
Moriey Cypress Company
Morley Cypress Company
Morley Cypress Company
Morley Cypress Company
Morley Cypress Company
Morley Cypress Company
Mcrley Cypress Company
Morley Cypress Company
Morley Cypress Company
Moriey Cypress Company
Morley Cypress Company
Moriey Cypress Company
Morley Cypress Company
Morley Cypress Company
Morley Cypress Company
Morley Cypress Company
Morley Cypress Company
Morley Cypress Company
E. B. Schwing
E. B. Schwing
E. B. Schwing
E B. Schwing
E. B. Schwing
E. B. Schwing
E. B. Schwing
E. B. Schwing
E. B. Schwing
E. B. Schwing
E. B. Schwing
E. B Schwing
E. B. Schwing
Wibert's Myrtle Grove
Wilbert's Myrtle Grove
Wibert's Myrtle Grove
Wilbert's Myrtie Grove
Wibert's Myrtle Grove
Wibert's Myrtle Grove
Wilbert's Myrtle Grove
Wilbert's Myrtle Grove
Wibert's Myrtie Grove
Wilbert's Myrtie Grove

\begin{tabular}{|c|c|}
\hline Acres \# & Well Identification \# \\
\hline 4415 & C 20 \\
\hline 4416 & C 21 \\
\hline 4417 & C 22 \\
\hline 4419 & C 23 \\
\hline 4420 & C 24 \\
\hline 4423 & C 25 \\
\hline 4425 & C 26 \\
\hline 4427 & C 27 \\
\hline 4428 & C $27 \mathrm{~A}$ \\
\hline 4429 & C 28 \\
\hline 4430 & C 30 \\
\hline 4431 & C 31 \\
\hline 4432 & C 32 \\
\hline 1433 & C 33 \\
\hline 4434 & C 34 \\
\hline 4435 & C 35 \\
\hline 4436 & C 36 \\
\hline 4437 & C 37 \\
\hline 4438 & C 38 \\
\hline 4439 & C 39 \\
\hline 4440 & C 40 \\
\hline 4441 & C 41 \\
\hline 4442 & C 42 \\
\hline 4443 & C 43 \\
\hline 4444 & C 44 \\
\hline 4446 & $\mathrm{H}_{2}$ \\
\hline 4447 & H3 \\
\hline 4448 & H4 \\
\hline 4449 & PE 7 \\
\hline 4450 & TGS 4 \\
\hline 4451 & DOE CH 1 \\
\hline 4452 & DOE CH 2 \\
\hline 4453 & Cavern 2 \\
\hline 4454 & Cavern 3 \\
\hline 4455 & Cavern 4 \\
\hline 4456 & Cavern 5 \\
\hline 4457 & Cavern 6 \\
\hline 4458 & Cavern 8 \\
\hline 4459 & Cavern BA \\
\hline 4460 & Cavern 9 \\
\hline 4461 & Cavern 15 \\
\hline 4462 & DOE $15 \mathrm{~A}$ \\
\hline 4463 & Cavern 18 \\
\hline 4464 & DOE 18A \\
\hline 4465 & Cavern 19 \\
\hline 4466 & DOE :9A \\
\hline 4467 & Allied 1 \\
\hline 4468 & Cavern 7 \\
\hline
\end{tabular}

Owner

Wilbert's Myrtle Grove Wilbert's Myrtle Grove

Wibert's Myrtle Grove

Wilbert's Myrtie Grove

Wibert's Myrte Grove

Wibert's Mytde Grove

Wibert's Myrtle Grove

Wilbert's Myrtle Grove

Wilbert's Myrtle Grove

Wilbert's Myrtle Grove

Wilbert's Myrtle Grove

Wiberts Myrte Grove

Wiberts Myrtle Grove

Wiberts Myrtle Grove

Wilbert's Myrtle Grove

Wilbert's Myrtle Grove

Wilbert's Myrtle Grove

Wilbert's Myrtie Grove

Wilber's Myrtle Grove

Wilbert's Myrtie Grove

Wibert's Myrte Grove

Wibert's Myrtle Grove

Wilbert's Myrtle Grove

Wibert's Myrtle Grove

Wilbert's Myrtle Grove

Wilbert's Myrtle Grove

Wilbert's Myrtle Grove

Wilbert's Myrtle Grove

Wilbert's Myrtle Grove

Wilbert's Myrtle Grove

Wilbert's Myrtle Grove

Department of Energy

Department of Energy

Department of Energy

Department of Energy

Department of Energy

Department of Energy

Department of Energy

Department of Energy

Department of Energy

Department of Eriergy

Department of Energy

Department of Energy

Department of Energy

Department of Energy

Department of Energy

Department of Energy

Wilbert Minerais Corp.

Wilbert Minerais Corp. 


\begin{tabular}{|c|c|c|}
\hline Acres \# & Well Identification \# & Owne: \\
\hline 4469 & Cavern 16 & Wilbert Minerais Corp. \\
\hline 4470 & Cavern 17 & Wibert Minerals Corp \\
\hline 4471 & Altied 24 & Witbert Minerals Corp \\
\hline 4472 & Allied 25 & Wilber: Minerals Coro. \\
\hline 4473 & 31 & Wiberi Minerais Corp \\
\hline 4474 & Ni & Wibert Minerais Corp \\
\hline 4475 & UTP & Wibert Minerals Corp \\
\hline 5201 & $C_{1}$ & Gay Union Corp. \\
\hline 5202 & $\mathrm{C} 2$ & Gay Union Cons \\
\hline 5203 & C 3 & Gay Union Corp. \\
\hline 5204 & C 4 & Gay Union Corp. \\
\hline 5205 & C 5 & Gay Union Corp. \\
\hline 5206 & C 6 & Gay Union Corp. \\
\hline 5208 & C 7 & Gay Union Corp \\
\hline 5210 & C 8 & Gay Union Corp \\
\hline 5212 & C 9 & Gay Union Corp. \\
\hline 5213 & C 10 & Gay Union Cort \\
\hline 5215 & $C: 1$ & Gay Union Corp \\
\hline 5216 & C 12 & Gay Union Corp. \\
\hline 5217 & C 13 & Gay Union Corp. \\
\hline 5219 & C 14 & Gay Union Corp \\
\hline 5220 & C 15 & Gay Union Corp \\
\hline 5221 & C 16 & Gay Uriton Corp. \\
\hline 5222 & $C_{17}$ & Gay Union Corp. \\
\hline 5223 & $C_{18}$ & Gay Union Corp. \\
\hline 5224 & C 19 & Gay Union Corp \\
\hline 5225 & C 20 & Gay Union Coro. \\
\hline 5226 & C 21 & Gay Union Cono. \\
\hline 5230 & C 22 & Gay Union Corp. \\
\hline 5231 & C 23 & Gay Union Corp. \\
\hline 5233 & C 24 & Gay Union Corp. \\
\hline 5234 & C 25 & Gay Union Corp. \\
\hline 5235 & C 26 & Gay Union Corp. \\
\hline 5236 & C 27 & Gay Union Corp. \\
\hline 5237 & C 28 & Gay Union Corp. \\
\hline 5238 & C 29 & Gay Union Corp. \\
\hline 5239 & C 30 & Gay Unron Corp. \\
\hline 5240 & C 31 & Gay Union Corp \\
\hline 5241 & C 32 & Gay Union Cor \\
\hline 5242 & C 33 & Gay Union Corp. \\
\hline 5243 & C 34 & Gay Union Corp. \\
\hline 5244 & C 35 & Gay Union Corp \\
\hline 5245 & C 36 & Gay Union Corp. \\
\hline 5246 & C 37 & Gay Union Corp. \\
\hline 5247 & C 38 & Gay Union Corp. \\
\hline 5248 & C 39 & Gay Union Corp. \\
\hline 5249 & C 40 & Gay Union Corp. \\
\hline 5250 & C 41 & Gay Union Corp. \\
\hline 5251 & C 42 & Gay Union Corp \\
\hline 5252 & C 43 & Gay Union Corp \\
\hline 5253 & C 44 & Gay Union Corp. \\
\hline
\end{tabular}

\begin{tabular}{|c|c|}
\hline Acres \# & Well Identification \# \\
\hline 5254 & C 49 \\
\hline 5255 & C 50 \\
\hline 5256 & C 51 \\
\hline 5257 & Gulf 1 \\
\hline 5259 & F 9 \\
\hline 5260 & $F 16$ \\
\hline 5261 & $F 20$ \\
\hline 5262 & $F 22$ \\
\hline 5263 & F 23 \\
\hline 5264 & F 24 \\
\hline 5265 & F 26 \\
\hline 5266 & F 29 \\
\hline 5267 & $F 30-1$ \\
\hline 5269 & $F 39$ \\
\hline 5270 & F 32 \\
\hline 5271 & F 33 \\
\hline 5273 & F 35 \\
\hline 5274 & F 37 \\
\hline 5275 & F 38 \\
\hline 5276 & F 39 \\
\hline 5277 & $F 40$ \\
\hline 5278 & $F 41$ \\
\hline 5279 & F 42 \\
\hline 5281 & F 43 \\
\hline 5282 & F 44 \\
\hline 5283 & F 45 \\
\hline 5284 & F 46 \\
\hline 5285 & F 47 \\
\hline 5286 & $F 48$ \\
\hline 5287 & F 49 \\
\hline 5288 & $F 50$ \\
\hline 5289 & $F 52$ \\
\hline 5290 & $F 54$ \\
\hline 5291 & $F 56$ \\
\hline 5292 & $F 58$ \\
\hline 5293 & F 59 \\
\hline 5295 & F 71 \\
\hline 5296 & $F 72$ \\
\hline 5297 & F 82 \\
\hline 5299 & Unknown \\
\hline 5301 & BA B-1 \\
\hline 5302 & $B A B-2$ \\
\hline 5303 & $B A B-3$ \\
\hline 5304 & $B A B-4$ \\
\hline 5305 & $B A B-5$ \\
\hline 5307 & $B A B-6$ \\
\hline 5308 & $B A B-7$ \\
\hline 5309 & BE 2 \\
\hline $53: 0$ & Choctaw 1 \\
\hline 5311 & Hall \& Damson 1 \\
\hline $53+2$ & State 1 \\
\hline
\end{tabular}

Owner

Gay Union Corp Gay Union Corp. Gay Union Conp. Gay Union Corp. Wibert Minerals Corp Wibert Minerals Corp. Wilbert Minerals Corp. Witbert Minerats Corp. Wittert Minerals Com Wither Minerals Corp Wiber Minerals Corp. Wiben Minerals Corp Wilbert Minerals Corp Wiber Minerals Corp Wibert Minerals Corp Wibert Minerals Corp. Wibert Minerals Corp. Wilbert Minerais Corp Wiber Minerals Corp. Wibert Mnerals Corp. Withen Mrerals Corp. Wibert Minerals Corp. Wibert Minerals Corp. Wibert Minerals Corp Wibert Minerals Corp Witbert Minerals Corp. Wilbert Minerals Corp Wiber Minerais Com. Wiber Minerals Corp. Wibert Minerals Corp. Wibert Minerals Corp Wibert Minerals Corp. Wilbert Minerals Corp Wilbert Minerals Corp. Wilbert Minerals Corp Witer Minerals Com. Wiber Minerals Conp Wiber Minerals Corp. Wibert Minerais Corp Wilbert Minerals Corp. Wibert Minerats Corp
Wiber Minerais Corp
E. B. Schwing et al
E. B. Schwing et a!
B. Schwing et al
E. B. Schwing et a!
E. B. Schwing et al
E. B. Schwing et al
E. B. Sctiwing et al
E. B. Sctrwing et al
E. B. Schwing et al
E. B. Schwing et al
E. B. Schwing et al 


\begin{tabular}{ll} 
Acres \# & Well Identification \# \\
\hline 5313 & Texas 1 \\
5314 & Texas 2 \\
5315 & Texas Levy 1 \\
5316 & Cavern 1 \\
5317 & Cavern 10 \\
5318 & Cavern 11 \\
5319 & Allied 12 \\
5320 & Cavern 13 \\
5321 & Cavern 20 \\
5322 & DOE 20A \\
5323 & F 2 \\
5324 & F 3 \\
5325 & F 4 \\
5326 & F 5 \\
5327 & F 6 \\
5328 & F 7 \\
5329 & F 8 \\
5330 & F 9 \\
5331 & F 10 \\
5332 & F 11 \\
5335 & F 12 \\
5336 & F 12-1 \\
5337 & F 13 \\
5339 & F 14 \\
5340 & F 15 \\
5341 & F 17 \\
5342 & F 18 \\
5344 & F 19 \\
5345 & F 21 \\
5346 & F 25 \\
5348 & F 28 \\
5349 & F 51 \\
5350 & F 53 \\
5351 & F 55 \\
5352 & F 60 \\
5353 & F 61 \\
5354 & F 62 \\
5355 & F 64 \\
5357 & F 65 \\
5358 & F 67 \\
5359 & F 68 \\
5360 & F 69 \\
5361 & F 70 \\
5362 & F 73 \\
5363 & F 74 \\
5364 & F 76 \\
5365 & F 78 \\
5366 & F 79 \\
5367 & FE 4 \\
5368 &
\end{tabular}

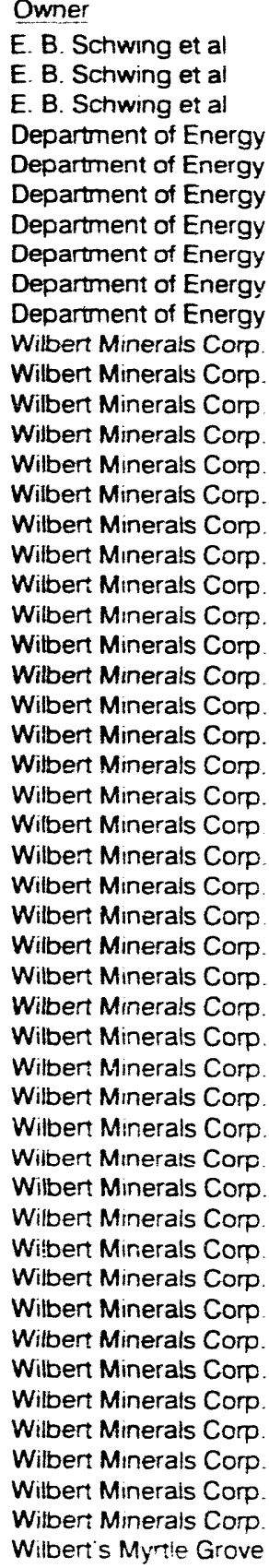

E. B. Schwing et

Department of Energy

ent of Energy

ent of Energy

Department of Energy

Department of Energy

Depart Energy

Wilbert Minerats Corp

Wiber Minerals Corp

Wilbert Minerals Corp.

Wilbert Minerals Corp

Wilbert Minerais Corp.

Wilbert Minerals Corp.

Wibert Minerals Corp.

Wibert Minerals Corp

Wibert Minerals Corp

Wibert Minerals Corp

Wilbert Minerals Corp.

Wilbert Minerals Corp

Wibert Mineras Corp

Wibert Minerals Corp

Wilbert Minerais Corp

Wilbert Minerals Corp

Wilter Minerals Corp.

Wibert Minerals Corp.

Wilbert Minerats Corp

Wilbert Minerals Corp.

Witbert Mirerals Corp.

Wiber Minerals Corp

Wibert Minerals Corp

Minerals Corp.

Wibert Minerals Corp.

Witbert Minerais Corp.

Wibert's Myrte Grove
Acres \#

5370

5372

$\mathbf{5 3 7 3}$
$\mathbf{5 3 7 5}$

5376

5378

5379

5380

5384

5384

5387

5388

5389

6001

6101

6103

6104
6105

6106

6107

6108

6110

6111
6112

6151

6152

6153

6154

6155

8201

9991

9992

9994

9996
Well Identification \#

C 9

C 11

C 12

C 13

C 14

C 15

C 16

C 16

C 29

TGS 1

TGS 3

TGS 5

TGS 6

TGS 7

TGS 8

$\mathrm{F} 80$

BE 12

C 18

Delta 3

F 34

F 36

$F 57$

57

663

F 66

Lone Star 1

BA 1

C 45

C 46

C 46

C 47

Delta 2

Property Boundary Markers

Property Boundary Markers

Property Boundary Markers

Property Boundary Markers

Property Boundary Markers

Property Soundary Markers
Owner

Wilbert's Myrtle Grove

Wilbert's Myrtle Grove

Wibert's Myrtle Grove

Wibert's Myrtle Grove

Witbert's Myrtle Grove

Wilbert's Myt

Wilbert's Myrtle Grove

Wilbert'- Myrtle Grove

Wilbert's Myrtle Grove

Wilbert's Myrtle Grove

Wibert's Myrtle Grove

Wilbert's Myrtle Grove

Wibert's Myrtie Grove

Wibert Minerals Corp.

Wibert Minerals Corp.

Wibert Minerals Corp.

Wilbert Minerals Corp.

Wilbert Minerals Corp.

Wilbert Minerals Corp.

Wibert Min

Wibert Minerals Con.

Wibert Minerals Corp.

Wibert Minerals Corp.

Gay Union Corp.

Gay Union Corp.

Gay Union Corp.

Gay Union Corp.

Gay Union Corp.

Wilbert Minerals Corp. 
BAYOU CHOCTAW GBOLOOICAL CHARACTBRIZATION

SUMMARY OF WELL LOO INTERPRETATIONS

WRLL NAME

\begin{tabular}{|c|c|c|c|c|c|c|c|c|}
\hline & 2801 & 2802 & 2803 & 2804 & 2805 & 2806 & 2807 & 2808 \\
\hline REF, RL. & 0 & 0 & 0 & 0 & 0 & 0 & 0 & 0 \\
\hline \multicolumn{9}{|l|}{$\begin{array}{c}=z= \pm \pi \ldots=\ldots= \\
\text { SYMBOL }\end{array}$} \\
\hline PL & & 980 & 1020 & & & & & \\
\hline LP & & & 2090 & 2105 & 2070 & 2275 & 2070 & \\
\hline Mi & 3055 & 3135 & 3000 & 3225 & 3045 & 3108 & 3025 & 2790 \\
\hline SA & 3625 & & 3545 & 3538 & 3640 & 3598 & 3525 & 3270 \\
\hline$\$ 1$ & 3878 & 3575 & 3895 & 3880 & 3882 & 3973 & 3868 & 3500 \\
\hline$\$ 2$ & 4350 & 3885 & 1290 & 4210 & 1265 & 4315 & 1205 & 3890 \\
\hline 83 & 4755 & 4440 & 4825 & 4800 & 4898 & 4943 & 4882 & 4505 \\
\hline 54 & 5285 & 4950 & 5065 & 5292 & 5380 & 5248 & 5235 & 4840 \\
\hline 55 & & 5545 & & 5958 & & 5858 & & 5380 \\
\hline 56 & & & & & & 6065 & & 5540 \\
\hline 57 & & & 6190 & & 6075 & 6393 & & 5732 \\
\hline s8 & 6130 & & 6365 & 6423 & 6230 & 6657 & 6225 & 6080 \\
\hline S9 & 6965 & & 7485 & 7545 & 7426 & 7845 & 7390 & 6955 \\
\hline HL & 7325 & & 8015 & 7885 & & 8325 & 7645 & 7190 \\
\hline $\mathrm{FF}$ & 7695 & 7560 & 8310 & 8400 & 8155 & 8852 & 8115 & 7675 \\
\hline MG & & & 8580 & 8520 & 8532 & & & 7885 \\
\hline $\mathrm{CH}$ & & & 8715 & 8650 & 8632 & & & \\
\hline$M T$ & 8340 & & 8910 & 8742 & 8790 & & & \\
\hline $\mathrm{BM}$ & & & 9410 & 9005 & 9150 & & & \\
\hline $\mathrm{TD}$ & 8390 & 7610 & 9460 & 9055 & 9200 & 8902 & 8165 & 7935 \\
\hline
\end{tabular}

\begin{tabular}{|c|c|c|c|c|c|c|c|c|}
\hline & 2809 & 2810 & 2811 & 2812 & 2813 & 2814 & 2815 & 2816 \\
\hline REF. EL, & 0 & 0 & 0 & 0 & 0 & 0 & 0 & 0 \\
\hline \multirow{2}{*}{\multicolumn{9}{|c|}{ 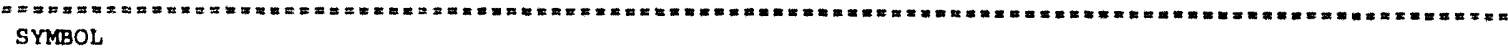 }} \\
\hline & & & & & & & & \\
\hline PL & & & & & 833 & & 985 & \\
\hline LP & & & & & 1908 & 2135 & 2050 & \\
\hline $\mathrm{Mi}$ & 2730 & 3012 & 2860 & 2860 & 2630 & 2671 & 2605 & 2983 \\
\hline SA & 3205 & 3240 & 3255 & 3355 & 3112 & 3160 & 3080 & 3392 \\
\hline S1 & 3420 & 3410 & 3515 & 3640 & 3340 & 3375 & 3280 & 3640 \\
\hline s2 & 3805 & 3705 & 3900 & 1005 & 3568 & 3670 & 3450 & 3955 \\
\hline 53 & 1400 & 4373 & 4595 & 1685 & 4352 & 4205 & 1045 & 4545 \\
\hline S4 & 4828 & 4715 & 5070 & 4935 & 4673 & 1495 & 4998 & 4920 \\
\hline S5 & 5320 & 5285 & 5465 & 5395 & & 5067 & 5050 & 5575 \\
\hline S6 & 5580 & 5588 & 5695 & 5558 & & 5235 & 5290 & 5835 \\
\hline s7 & 5785 & 5806 & 6008 & 6048 & & & & 6230 \\
\hline SB & 5872 & 5968 & 6210 & 6210 & 5700 & 5488 & & 6445 \\
\hline$\$ 9$ & 6805 & 6815 & 6820 & 7175 & 6435 & & & 7355 \\
\hline HL & & 7273 & 7420 & 7305 & 6930 & & & 7862 \\
\hline $\mathbf{F F}$ & 7325 & 7550 & 7682 & 7730 & & & & 8320 \\
\hline MG & 7650 & & 8010 & 8070 & & & & 8460 \\
\hline $\mathrm{CH}$ & 7845 & & & & & & & 8740 \\
\hline$M T$ & & & & & & & & 8882 \\
\hline BM & & & & & & & & 9270 \\
\hline TD & 7895 & 7600 & 8060 & 8120 & 6980 & 5538 & 5340 & 9320 \\
\hline
\end{tabular}




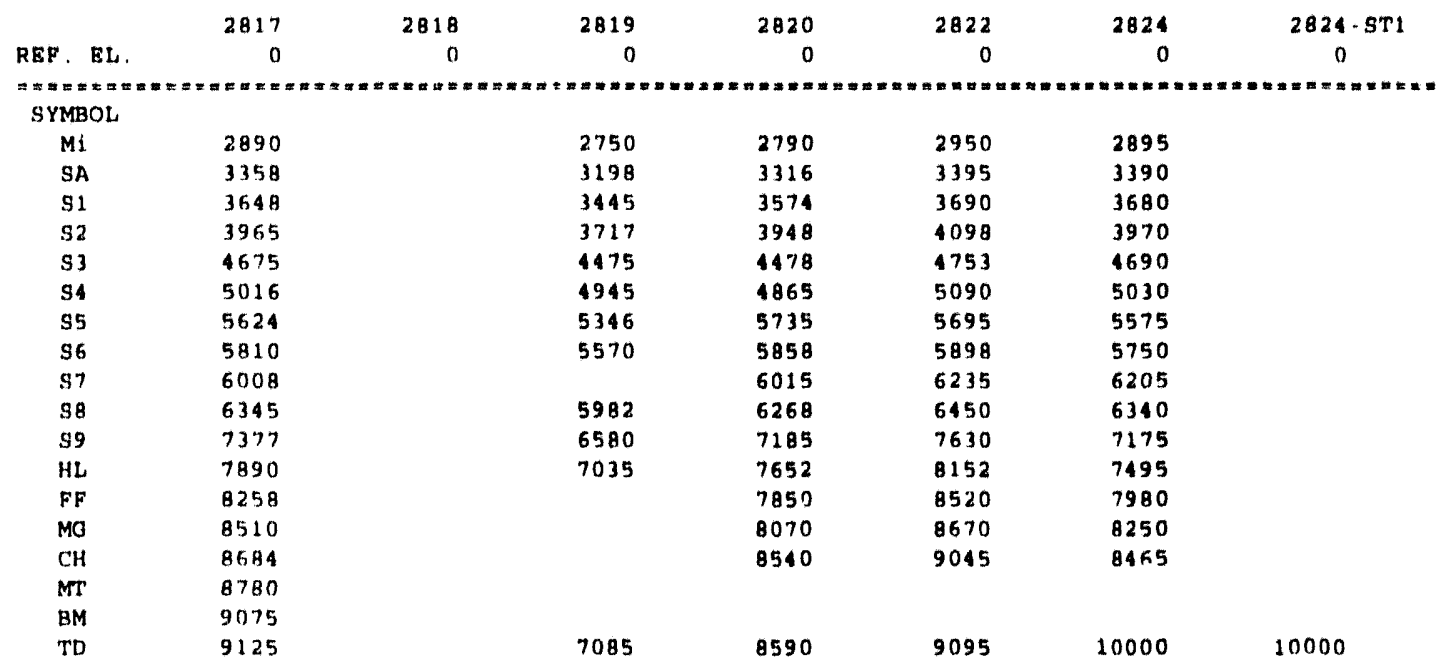

\begin{tabular}{|c|c|c|c|c|c|c|c|c|}
\hline & 2825 & $2825-5 T 1$ & 2827 & 2901 & 2902 & 2904 & 2907 & 2908 \\
\hline REF, EL, & 0 & $n$ & 0 & 0 & 0 & 0 & 0 & 0 \\
\hline \multicolumn{9}{|c|}{$\begin{array}{l}F=m=m=m=m \\
\text { SYMBOL. }\end{array}$} \\
\hline $\begin{array}{l}\text { SYMBOL } \\
\text { PL }\end{array}$ & & & & & & & & \\
\hline Pt & & & & & & & & 1015 \\
\hline $\mathrm{MP}$ & & & & & & & & 1680 \\
\hline LP & & & 2005 & & 2160 & 2375 & 2560 & 2190 \\
\hline $\mathrm{Mi}$ & & & 2745 & 2930 & 2900 & 3145 & 3165 & 3090 \\
\hline SA & & & 3260 & 3400 & & 3425 & 3468 & 3568 \\
\hline 31 & 3562 & & 3120 & 3655 & 3395 & 3738 & 3752 & 3830 \\
\hline $\mathrm{S2}$ & 3965 & & 3640 & 4035 & 3670 & 4065 & 4155 & 4155 \\
\hline 83 & 4702 & & 4480 & 4740 & 4480 & 4750 & 4740 & 4880 \\
\hline $\mathbf{3 4}$ & 5030 & & 4695 & 4990 & 4930 & 5125 & 5130 & 5145 \\
\hline 95 & 5560 & & 5250 & 5460 & 5370 & 5493 & 5698 & 5760 \\
\hline S6 & 5785 & & 5505 & 5640 & 5675 & 5760 & 6038 & 5915 \\
\hline S7 & 6160 & & & 6160 & 6060 & 6225 & 6343 & 6315 \\
\hline 38 & 6302 & & 5868 & 6320 & 6290 & 6350 & 6425 & 6745 \\
\hline 89 & 7010 & & 6310 & 7390 & 6860 & 7305 & 7347 & 7700 \\
\hline HL & 7542 & 7532 & 6715 & 7535 & 7395 & 7675 & 7798 & \\
\hline FF & 76.20 & 7590 & & 7960 & 7530 & 8095 & 8202 & 8222 \\
\hline MG & 7928 & 7902 & & B358 & & 8290 & B405 & 9080 \\
\hline $\mathrm{CH}$ & 8215 & & & & & & 8732 & 9312 \\
\hline$M T$ & & & & & & & 9068 & 9600 \\
\hline BM & & & & & & & 9380 & \\
\hline Tt) & 8216 & 7902 & 6765 & 8408 & 7580 & 8340 & 9430 & 9650 \\
\hline
\end{tabular}

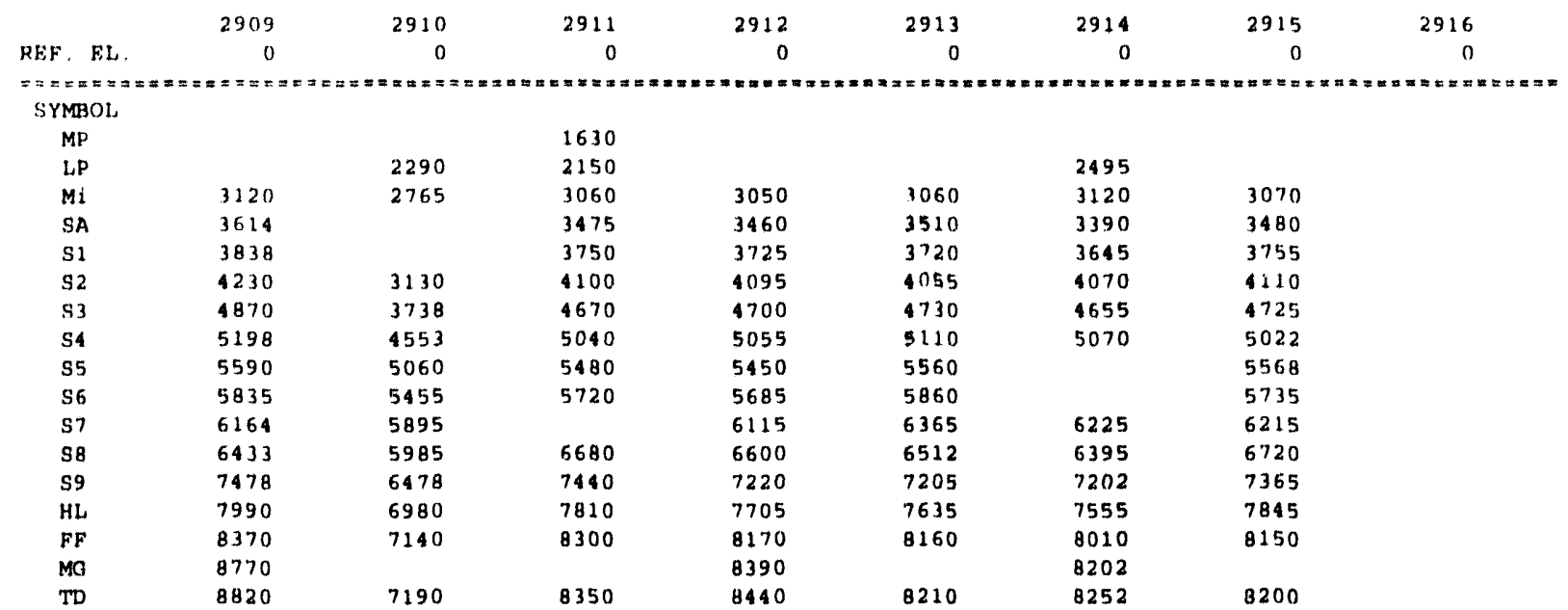




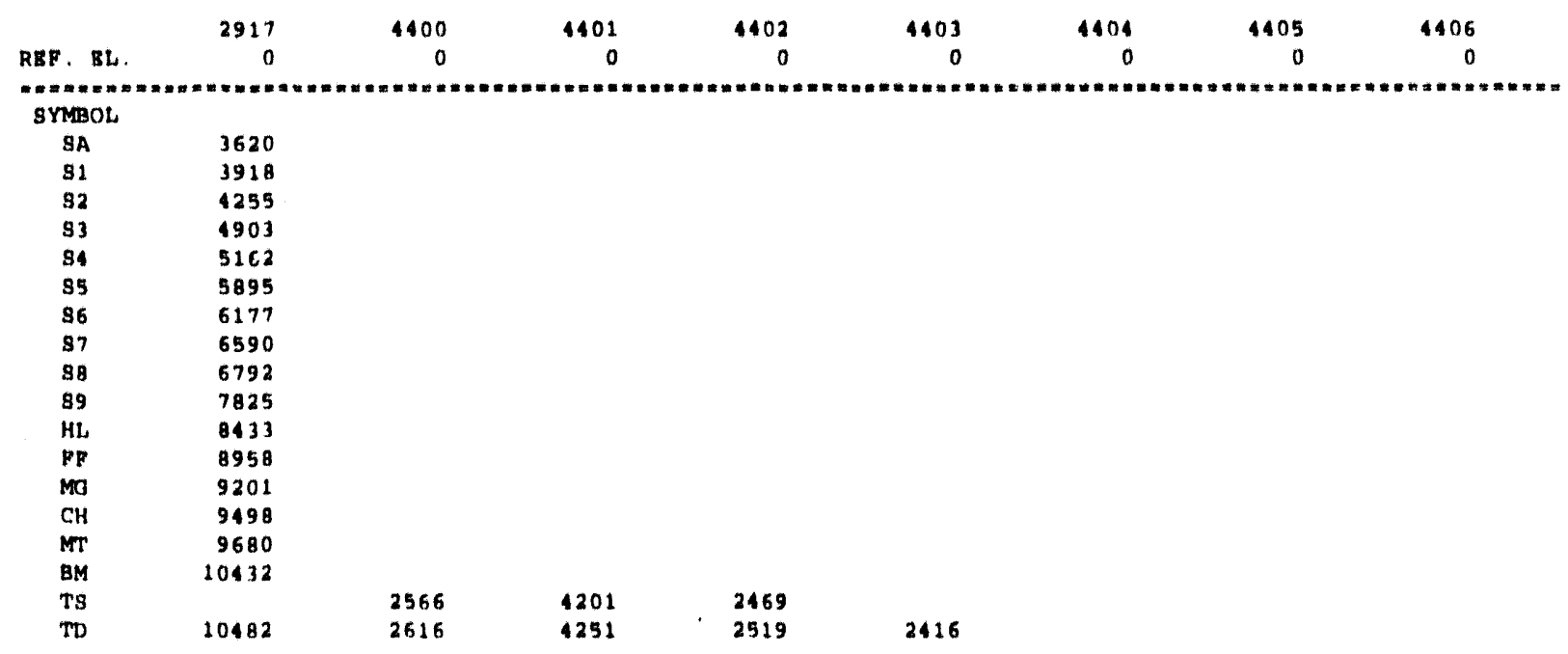

\begin{tabular}{|c|c|c|c|c|c|c|c|c|}
\hline & 4107 & $4407 \cdot 5 \mathrm{~T} 1$ & 4407.572 & $4107.5 T 3$ & $\begin{array}{r}4411 \\
0\end{array}$ & $4411 \cdot 5 \mathrm{ST} 1$ & $\begin{array}{c}1411 \cdot 8 \mathrm{TT} \\
0\end{array}$ & $\begin{array}{r}4414 \\
0\end{array}$ \\
\hline $\begin{array}{l}\text { RBF, RL. } \\
== \pm= \pm=n=1\end{array}$ & $=0$ & $\begin{array}{c}0 \\
m=m=m=m\end{array}$ & $\begin{array}{c}0 \\
m=m=-m=m \ldots=\end{array}$ & $\begin{array}{c}0 \\
m z=z=z-m=n\end{array}$ & $\ln _{n=\infty}^{0}$ & $\begin{array}{c}0 \\
m=m=m=n=0\end{array}$ & 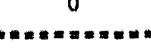 & $m=m=m$ \\
\hline \multicolumn{9}{|l|}{ SYMBOL } \\
\hline MP & & & & & 1340 & & & \\
\hline LP & & & & & 2905 & & & 1280 \\
\hline$M i$ & & & & & & & & 1720 \\
\hline SA & & & & & 3005 & & & \\
\hline $\mathbf{s 2}$ & & & & & 3360 & & & \\
\hline 93 & & & & & 3740 & & & \\
\hline 84 & & & & & 1010 & & & \\
\hline $\mathrm{Ts}$ & & & & & 5235 & 4828 & 4814 & \\
\hline TD & 10000 & 10000 & 10000 & 10000 & 10000 & 10000 & 10000 & 1770 \\
\hline
\end{tabular}

\begin{tabular}{|c|c|c|c|c|c|c|c|c|}
\hline & 4415 & 4416 & 4417 & $4417 . \mathrm{ST} 1$ & 4419 & 4120 & $4120.8 T 1$ & $4420-\operatorname{ST2} 2$ \\
\hline REF, EL, & 0 & 0 & 0 & 0 & 0 & 0 & 0 & 0 \\
\hline$x=\# \| x=z=$ & $m=x=2$ & $=x=0$ & $m=2=2 x$ & 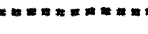 & $=2= \pm \ldots$ & 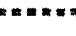 & 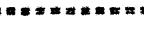 & $m=z=z=z=n$ \\
\hline SYMBOL & & & & & & & & \\
\hline MP & 1320 & 1345 & & & 1365 & & 1285 & \\
\hline LP & 1860 & 1980 & & & 1910 & 1410 & 1975 & \\
\hline $\mathrm{Mi}$ & & & & & & 1934 & & \\
\hline SA & 2865 & 2905 & & & 3142 & & 2872 & \\
\hline$\$ 1$ & 2995 & & & & & 2900 & & \\
\hline S2 & 3120 & 3050 & & & & 3102 & & \\
\hline 33 & 3395 & 3405 & & & & & & \\
\hline TS & & & & & & 3910 & & \\
\hline TD & 3445 & 3455 & 10000 & 10000 & 3192 & 3911 & 10000 & 10000 \\
\hline
\end{tabular}

\begin{tabular}{|c|c|c|c|c|c|c|c|c|}
\hline & 4423 & $4423 \cdot \mathrm{ST} 1$ & 4425 & 4427 & 4428 & 4429 & 4430 & 4431 \\
\hline REF . EL. & 0 & 0 & 0 & 0 & 0 & 0 & 0 & 0 \\
\hline \multicolumn{9}{|c|}{ 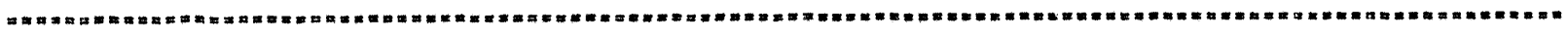 } \\
\hline \multicolumn{9}{|c|}{ SYMBOL } \\
\hline PL & 885 & 885 & 975 & & & 1190 & 870 & \\
\hline MP & 1270 & 1187 & 1275 & & & 1670 & 1400 & 1385 \\
\hline$L P$ & & & 2020 & & 2215 & 2190 & 2030 & 1920 \\
\hline Mi & & 2650 & 2805 & & & & 2435 & \\
\hline$S A$ & & & 3150 & & & 3168 & 3160 & 2830 \\
\hline S1 & & & & & & 3408 & 3395 & \\
\hline $\mathbf{3 2}$ & & & 3540 & & & 3565 & 3555 & 3210 \\
\hline 83 & & & 4058 & & & & & \\
\hline 54 & & & 4375 & & & 4485 & 4523 & \\
\hline 89 & & & & & & 5424 & & \\
\hline TS & 2010 & & 4743 & 1290 & 995 & 4735 & 4868 & \\
\hline BS & & & & & 1880 & 5205 & & \\
\hline TD & 2060 & 2700 & 4794 & 1340 & 10000 & 5474 & 4918 & 3260 \\
\hline
\end{tabular}




\begin{tabular}{|c|c|c|c|c|c|c|c|c|}
\hline & $4 \mathbf{4 3 2}$ & 4433 & 4434 & 4435 & 4436 & 4437 & 4438 & 4439 \\
\hline REP, BL, & 0 & 0 & 0 & 0 & 0 & 0 & 0 & 0 \\
\hline \multicolumn{9}{|l|}{ 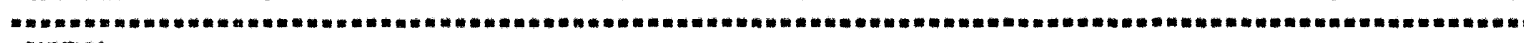 } \\
\hline \multicolumn{9}{|l|}{ BYNBOL } \\
\hline MP & & 1370 & 1370 & 1345 & 1395 & 1375 & 1300 & 1380 \\
\hline LP & 1764 & 1898 & 1902 & 1908 & 1925 & 1895 & 1920 & 1945 \\
\hline SA & & 3045 & 2996 & 2975 & 3025 & 2973 & 2950 & 3050 \\
\hline 81 & & & & & & & 3072 & \\
\hline 82 & & 3338 & 3248 & 3250 & 3202 & 3140 & 3295 & 3290 \\
\hline $\mathbf{9 3}$ & & 3695 & 3614 & 3650 & 3850 & 3595 & & 3787 \\
\hline 84 & & 3930 & 1013 & & 4074 & 3805 & 3578 & 4195 \\
\hline 95 & & & & & 4570 & & 4120 & 4500 \\
\hline 86 & & & & & 1879 & & 4385 & \\
\hline 88 & & & & & 5153 & & & \\
\hline $\mathrm{Ts}$ & 2568 & 1670 & & & & & 4593 & \\
\hline \multirow[t]{2}{*}{ TD } & 2618 & 4720 & 4065 & 3700 & 5205 & 3855 & 4643 & 4550 \\
\hline & 4440 & 1411 & 4412 & 1443 & 4444 & 1446 & 4447 & 4448 \\
\hline REF, EL. & 0 & 0 & 0 & 0 & 0 & 0 & 0 & 0 \\
\hline \multicolumn{9}{|l|}{$\begin{array}{l}m= \pm=1=-\infty \\
\text { SYMBOL }\end{array}$} \\
\hline $\begin{array}{c}\text { SYMBOL } \\
\text { PL }\end{array}$ & 858 & & & & & & & \\
\hline MP & 1337 & 1260 & 1400 & 1420 & 1375 & 1390 & & \\
\hline LP & 1975 & 1840 & 1928 & 1995 & 1895 & 1872 & & \\
\hline Mi & 2690 & & & & & & & \\
\hline SA & 2998 & 2810 & 3028 & 2990 & 2995 & 3030 & & \\
\hline 32 & 3140 & 3410 & 3205 & 3172 & 3160 & 3360 & & \\
\hline 53 & 3955 & & 3845 & & 3660 & & & \\
\hline 84 & & & 1058 & 3885 & 3863 & & & \\
\hline 85 & & & 4445 & 1405 & & & & \\
\hline 96 & & & 4590 & 4620 & & & & \\
\hline 88 & 1725 & & 5145 & 5160 & & & & \\
\hline 39 & 5750 & & & & & & & \\
\hline $\mathrm{Ts}$ & 5275 & & & & & & & \\
\hline TD & 5800 & 3560 & 5195 & 5210 & 3913 & 3411 & & \\
\hline
\end{tabular}

\begin{tabular}{|c|c|c|c|c|c|c|c|c|}
\hline & 4449 & 4450 & 4451 & 4452 & $\$ 453$ & 4454 & $\$ 455$ & 4456 \\
\hline RBF, BL. & 0 & 0 & 0 & 0 & 0 & 0 & 0 & 0 \\
\hline \multirow{2}{*}{\multicolumn{9}{|c|}{ 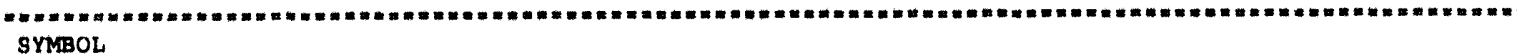 }} \\
\hline \multirow{2}{*}{\multicolumn{9}{|c|}{ Mi }} \\
\hline & & & & & & & & \\
\hline TS & 2448 & & 658 & 646 & 639 & 791 & 662 & 645 \\
\hline \multirow[t]{2}{*}{$T D$} & 2498 & 530 & 708 & 696 & 689 & 1925 & 712 & 695 \\
\hline & 4457 & 4458 & 4459 & 1460 & 1461 & 1462 & 4463 & 4464 \\
\hline REP， EL. & 0 & 0 & 0 & 0 & 0 & 0 & 0 & 0 \\
\hline \multicolumn{9}{|c|}{ 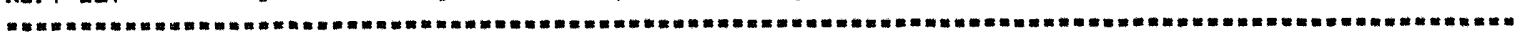 } \\
\hline $\mathrm{TS}$ & & 740 & 776 & 890 & 637 & 613 & 857 & 805 \\
\hline TD & & 790 & 2026 & 940 & 3347 & 663 & 4335 & 855 \\
\hline
\end{tabular}

\begin{tabular}{|c|c|c|c|c|c|c|c|c|}
\hline & 4465 & 4466 & 4467 & 4468 & 4469 & $\$ 470$ & 4471 & 4472 \\
\hline REF. EL, & 0 & 0 & 0 & 0 & 0 & 0 & 0 & 0 \\
\hline \multicolumn{9}{|c|}{ Non } \\
\hline \multicolumn{9}{|c|}{ SYMBOL } \\
\hline Ts & 850 & 862 & 655 & 850 & 800 & 660 & & \\
\hline $\mathrm{TD}$ & 4320 & 912 & 705 & 900 & 850 & 4100 & & \\
\hline
\end{tabular}

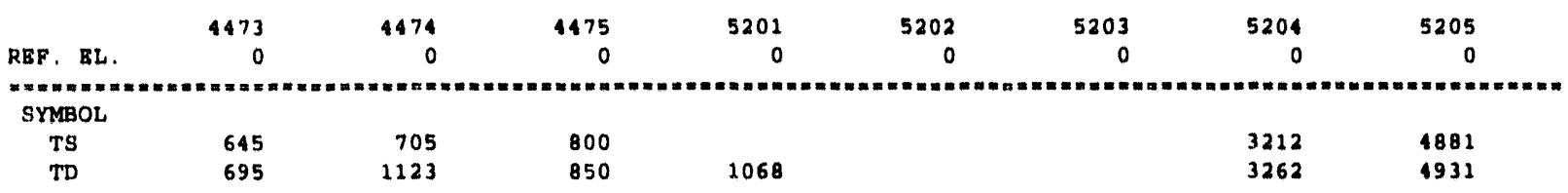




\begin{tabular}{|c|c|c|c|c|c|c|c|c|}
\hline & 5206 & $5206 \cdot 8 \mathrm{r} 1$ & 5208 & $5208-8 T 1$ & 5210 & $5210-8 \mathrm{~T} 1$ & 5212 & \\
\hline REF, EL. & 0 & 0 & 0 & 0 & 0 & 0 & 0 & \\
\hline 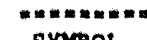 & 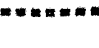 & $t= \pm= \pm$ & $m=\operatorname{man}=0$ & 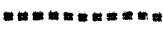 & $x+\infty \times+\infty$ & 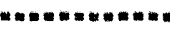 & 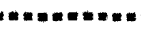 & \\
\hline SYMAOL & & & & & & & & \\
\hline PL & & & & & 995 & & & \\
\hline MP & & & & & 1555 & & & \\
\hline LP & & & & & 2190 & & & \\
\hline Mi & & & & & 2800 & & & \\
\hline 9A & & & & & 3210 & & 2490 & \\
\hline 31 & & & & & & & 3090 & \\
\hline 92 & & & & & 3660 & & 3465 & \\
\hline 83 & & & & & 1392 & & & \\
\hline 84 & & & 4520 & & 1700 & & 4060 & \\
\hline s5 & & & 5045 & & 5538 & & & \\
\hline $\mathbf{8 6}$ & & & & & 5765 & & & \\
\hline $\mathbf{8 9}$ & & & & & & & 5030 & \\
\hline HL & & & & & & & 5450 & \\
\hline Ts & & & & & & & 6162 & \\
\hline TD & 4591 & 10000 & 5045 & 10000 & & 10000 & 6212 & \\
\hline & 5213 & $5213 \cdot 87^{1} 1$ & 5215 & 5216 & 5217 & $5217.5 \mathrm{~T} 1$ & 5219 & 5220 \\
\hline REF BL. & 0 & 0 & 0 & 0 & 0 & 0 & 0 & 0 \\
\hline $\begin{array}{l}* *=* *=* \\
\text { SYMBOL }\end{array}$ & $m=m=m$ & 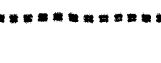 & $m= \pm= \pm$ & 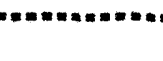 & 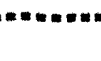 & 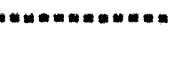 & 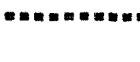 & 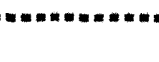 \\
\hline $\mathrm{PL}$ & & & 935 & & & & & 930 \\
\hline MP & & & 1565 & 1485 & & & & 1465 \\
\hline LP & 2210 & & 2365 & 2160 & & & & 2155 \\
\hline$M d$ & 2440 & & 2845 & 2620 & & & & 2715 \\
\hline SA & 3130 & & 3465 & 3300 & & & & 3199 \\
\hline 81 & 3350 & & & 3575 & & & 2890 & 3440 \\
\hline $\mathbf{9 2}$ & 3590 & & 1060 & 3832 & & & 3100 & 3682 \\
\hline 93 & 3990 & & 4610 & 4360 & & & & 4335 \\
\hline $\mathbf{s 4}$ & 4270 & & 5090 & 4845 & 8325 & 8260 & & 4770 \\
\hline $\mathbf{8 5}$ & 5050 & & & 5610 & 9327 & 8770 & & \\
\hline 96 & & & & & & 9420 & & \\
\hline 57 & & & & 6060 & & & & \\
\hline s8 & 5710 & & 6250 & 6160 & & & & \\
\hline 99 & 6430 & & 6940 & 7112 & & & & \\
\hline HL & & & & 7608 & & & & \\
\hline $\mathbf{F F}$ & 6860 & & 7395 & 7870 & & & & \\
\hline$M$ & 7170 & & 7515 & 8095 & & & & \\
\hline $\mathrm{CH}$ & & & 7685 & & & & & \\
\hline$M T$ & & & 7990 & & & & & \\
\hline $\mathrm{BM}$ & & & 8290 & & & & & \\
\hline $\mathrm{NB}$ & & & $8 / 10$ & & & & & \\
\hline TS & & & & & 7735 & 7790 & 3200 & \\
\hline Bs & & & & & $71+0$ & 7112 & & \\
\hline TD & 7170 & 7170 & 8760 & 8145 & 9377 & 9470 & 3250 & 1820 \\
\hline & 5221 & 5222 & 5223 & 5224 & 5225 & 5226 & $5226 \cdot 5 T 1$ & $5226-\mathrm{ST} 2$ \\
\hline REF , EL. & 0 & 0 & 0 & 0 & 0 & 0 & 0 & 0 \\
\hline 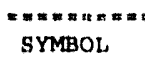 & 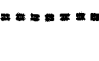 & 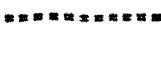 & $m= \pm= \pm=$ & 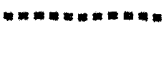 & $m+x= \pm x=$ & 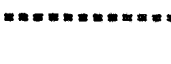 & $m= \pm=m=n+m$ & 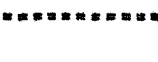 \\
\hline $\mathrm{PL}$ & 1145 & 1078 & 1062 & 1058 & 1040 & 1060 & & \\
\hline MP & & 1512 & 1654 & & 1578 & & & \\
\hline LP & & 2150 & 2315 & 2345 & 2245 & 2300 & & \\
\hline $\mathrm{Mi}$ & 2972 & 2762 & 2952 & 3032 & 2740 & 3002 & & \\
\hline SA & & 3260 & 3485 & 3480 & 3295 & 3530 & & \\
\hline $\mathbf{S} 1$ & & & 3740 & 3715 & 3555 & 3815 & & \\
\hline s2 & 4000 & 3830 & 1140 & 4098 & 3745 & 4095 & & \\
\hline 93 & 4499 & 4302 & 1710 & 4660 & 4325 & 4638 & & \\
\hline S4 & 4949 & 4770 & 5175 & 5078 & 4758 & 5020 & & \\
\hline$\$ 5$ & 5540 & 5535 & & & & 5580 & & \\
\hline 56 & 5820 & & & & & 5775 & & \\
\hline S7 & 6135 & 5945 & & & & 6145 & & 6145 \\
\hline 98 & 6292 & 6035 & 5886 & 5820 & 5750 & 6195 & & 6192 \\
\hline 59 & & 6930 & 6658 & 6530 & & 6945 & 6980 & 6755 \\
\hline HL & 6935 & 7330 & 6975 & 7085 & & 7355 & 7515 & 7150 \\
\hline $\mathrm{FF}$ & 7302 & 7843 & 7405 & 7390 & & 7600 & 7890 & 7450 \\
\hline MO & 7540 & 8145 & 7590 & & & & & \\
\hline $\mathrm{CH}$ & 7820 & 8450 & & & & & & \\
\hline MT & 8082 & & 7815 & 7718 & & & & \\
\hline BM & 8750 & & & & & & & \\
\hline Ts & & & 8205 & 8105 & & & & 7775 \\
\hline$T D$ & 8800 & 8500 & 8255 & 8155 & 5800 & 10000 & 7891 & 7451 \\
\hline
\end{tabular}


BAYOU CHOCTAW OROLOOICAL CHARACTERIZATION

gUMAaRY OF WELL LOO INTERPRETATIONg

WBLL NAME

\begin{tabular}{|c|c|c|c|c|c|c|c|c|}
\hline & 5230 & 5211 & $5231 \cdot 8 \mathrm{~T} 1$ & 5273 & 5234 & 5235 & 5236 & 5237 \\
\hline REF， BL。 & 0 & 0 & 0 & 0 & 0 & 0 & 0 & 0 \\
\hline \multicolumn{9}{|c|}{ 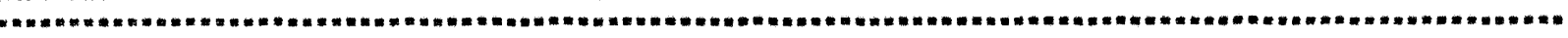 } \\
\hline \multicolumn{9}{|c|}{ SYMBOL } \\
\hline PL & 1010 & & & & & & & \\
\hline MP & 1625 & & & & & & & \\
\hline LP & 1990 & 2195 & & 2308 & 2245 & 1400 & 2105 & \\
\hline M1 & 2880 & 2681 & & 2778 & 2855 & 1953 & 2648 & \\
\hline SA & 3445 & 3106 & & 3310 & 3375 & 2560 & 3158 & \\
\hline 81 & 3715 & 3320 & & 3560 & 3650 & 2910 & 3405 & \\
\hline 82 & 4060 & 3825 & & 3840 & 3950 & 3075 & 3670 & \\
\hline 83 & 4518 & 4045 & & 4530 & 1635 & 1500 & 4258 & \\
\hline 94 & 5110 & $\$ 240$ & & 1875 & 5103 & 3650 & 4668 & 4270 \\
\hline 85 & & 5000 & & 5325 & 5180 & & 5180 & \\
\hline 86 & & 5210 & & 5533 & & & & \\
\hline 87 & & & & & 5676 & & 5810 & \\
\hline 88 & 5708 & 5720 & & 6312 & 5728 & & 5882 & \\
\hline 99 & 6735 & & & 6638 & 6350 & & 6210 & \\
\hline HL & & 6250 & & 1265 & 6760 & & 6630 & \\
\hline FF & 7336 & & & & & & 7092 & \\
\hline MO & 7667 & & & & & & & \\
\hline $\mathrm{CH}$ & 7918 & & & & & & & \\
\hline$T S$ & & & & & & 3825 & & 5194 \\
\hline $\mathrm{TD}$ & 7998 & 6251 & 10000 & 7315 & 6810 & 3875 & 7142 & 5244 \\
\hline
\end{tabular}

\begin{tabular}{|c|c|c|c|c|c|c|c|c|}
\hline & 5238 & 5239 & 5240 & 5241 & 5242 & 5243 & 5244 & 5245 \\
\hline REF . BL, & 0 & 0 & 0 & 0 & 0 & 0 & 0 & 0 \\
\hline$\Rightarrow= \pm=m=0$ & 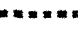 & & $m=0$ & $== \pm=$ & $n=\infty$ & 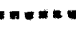 & $\Leftrightarrow=0$ & 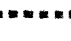 \\
\hline \multicolumn{9}{|l|}{ SYMBOL } \\
\hline $\begin{array}{l}\text { PL } \\
\text { MP }\end{array}$ & & 1705 & & & 1455 & 1395 & 1342 & \\
\hline $\begin{array}{l}\text { MP } \\
\text { LP }\end{array}$ & 1680 & 2355 & 1620 & 2313 & 2247 & 1998 & 1965 & 1662 \\
\hline $\begin{array}{l}\text { LP } \\
M i\end{array}$ & 2198 & 2870 & & 2790 & 2705 & 2670 & & 2100 \\
\hline Mi & & & & & & & 2485 & 2100 \\
\hline SA & 2550 & 3298 & & 3395 & 3040 & 2978 & 2945 & 2705 \\
\hline $\mathbf{3 1}$ & 3095 & 3605 & 3015 & 3665 & 3245 & 3130 & 3235 & 3045 \\
\hline 52 & 3245 & 3875 & 3135 & 3970 & 3460 & 3495 & 3570 & 3200 \\
\hline S3 & 3745 & 4350 & & 1130 & & & 3905 & 3718 \\
\hline 84 & 4008 & 4540 & 3800 & 4730 & 1082 & 3876 & 1125 & 1178 \\
\hline 95 & & 5410 & & 5315 & 1828 & 4510 & & \\
\hline 96 & & 5605 & & & 5050 & 1648 & & 4590 \\
\hline 97 & 4800 & 6010 & & & & & & \\
\hline 88 & & 6145 & & 5715 & 5655 & 5490 & 5695 & \\
\hline 59 & & 6682 & & 6565 & 6450 & & & \\
\hline HL & & 6973 & & 6880 & & & & \\
\hline $\mathrm{FP}$ & & 7418 & & & & & & \\
\hline$M O$ & & 7590 & & & & & & \\
\hline$M T$ & & 8160 & & & & & & \\
\hline BM & & 8485 & & & & & & \\
\hline TS & & & 1460 & & & & & 4790 \\
\hline TD & 1850 & 8535 & 4510 & 6930 & 6500 & 5540 & 5745 & 4840 \\
\hline
\end{tabular}




\begin{tabular}{|c|c|c|c|c|c|c|c|c|}
\hline & 5246 & 5247 & 5248 & 5249 & 5230 & 5251 & 5252 & 5253 \\
\hline REF, RL. & 0 & 0 & 0 & 0 & 0 & 0 & 0 & 0 \\
\hline \multirow{2}{*}{\multicolumn{9}{|c|}{ 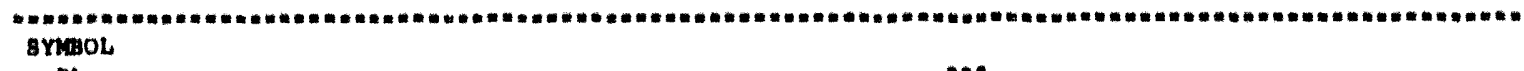 }} \\
\hline & & & & & & & & \\
\hline & & & & & 998 & & & \\
\hline NP & & & 1468 & 1535 & 1370 & & 1545 & \\
\hline LP & 1715 & 1560 & 2148 & 2105 & 2009 & 2259 & 2285 & 2145 \\
\hline$M i$ & 2145 & 2050 & 2782 & 2750 & 2400 & 2770 & 2825 & 2845 \\
\hline BA & 1045 & 3033 & 1078 & 1173 & & 3158 & 1230 & 3514 \\
\hline 81 & & 3145 & 3310 & 3412 & 2990 & 3450 & 3505 & 3724 \\
\hline 82 & & & 3510 & 3670 & 3215 & 3638 & 3762 & 1050 \\
\hline 83 & 3005 & 3490 & & 1188 & & 1120 & 4272 & 1630 \\
\hline 84 & 3865 & 3660 & 1075 & 4417 & 3750 & 1240 & 4606 & 1989 \\
\hline 85 & 4703 & 1250 & 1805 & 3065 & & 5125 & & 5445 \\
\hline$\$ 6$ & & 4615 & 5070 & 5295 & & 5325 & & 5621 \\
\hline 97 & & & & 5783 & & 5806 & & \\
\hline 88 & 5450 & & & 5845 & & 5800 & & 6375 \\
\hline 89 & & & & 6660 & & & & 6910 \\
\hline$H L$ & & & & 7072 & & 6362 & & 7135 \\
\hline $\mathbf{P F}$ & & & & 7410 & & 6910 & & 7569 \\
\hline$M O$ & & & & & & 7190 & & 7690 \\
\hline $\mathrm{CH}$ & & & & & & 7615 & & 7990 \\
\hline$M r$ & & & & & & & & 0255 \\
\hline BM & & & & & & & & 8440 \\
\hline \multirow[t]{2}{*}{$T V$} & 5500 & 4665 & 5120 & 7160 & 3800 & 7665 & 1658 & 0490 \\
\hline & 5254 & 5255 & 5256 & 5257 & 5257.871 & 5259 & 5260 & 5261 \\
\hline REF， KL. & 0 & 0 & 0 & 0 & 0 & 0 & 0 & 0 \\
\hline \multicolumn{9}{|l|}{ SYMBOL } \\
\hline$P_{1}$ & & & & & & 695 & 953 & 755 \\
\hline MP & & & & & & 1460 & & 1385 \\
\hline LP & 2312 & & & & & 1985 & & 1939 \\
\hline$M i$ & 3018 & & & & & 2545 & & \\
\hline \$A & 3589 & & 3570 & 3202 & & 3034 & & 3118 \\
\hline 81 & 3915 & & & 3480 & & 3220 & & \\
\hline 82 & 1200 & & 1105 & 3098 & & 1350 & & 3380 \\
\hline 83 & 4970 & & 1785 & 4105 & & 3920 & & 3750 \\
\hline 84 & 5286 & & 5232 & 1810 & & 4340 & & 4055 \\
\hline 95 & 6043 & & 5942 & 5345 & & & & \\
\hline 86 & 6360 & & 6238 & 5370 & & & & \\
\hline 97 & & & & 6118 & & & & \\
\hline 88 & 6670 & & 6392 & 6230 & & 4980 & & \\
\hline 99 & 7785 & & 7445 & 7020 & & 5585 & & \\
\hline HL. & 8110 & & 7550 & 7195 & & & & \\
\hline $\mathrm{PF}$ & 8663 & & 7937 & 7723 & & & & \\
\hline MO & 9198 & & & B125 & & & & \\
\hline $\mathrm{CH}$ & & & 8115 & & & & & \\
\hline $\mathbf{M T}$ & & & 8480 & 8610 & & & & \\
\hline BM & & & 9045 & 8975 & & & & \\
\hline $\mathrm{NB}$ & & & 9470 & & & & & \\
\hline Ts & & & & & & & 1412 & 4798 \\
\hline \multirow[t]{2}{*}{$T w$} & 9248 & & 9520 & 6975 & 10000 & 5635 & 1462 & 1848 \\
\hline & 5262 & 5263 & 5264 & 5265 & 5266 & 5267 & $5267 \cdot 5 T 1$ & 5269 \\
\hline REF，EL. & 0 & 0 & 0 & 0 & 0 & 0 & 0 & 0 \\
\hline \multicolumn{9}{|l|}{ SYMBOL } \\
\hline PL & 800 & & & & & & & 840 \\
\hline MP & 1365 & 1407 & 1383 & 1430 & 1345 & & & 1370 \\
\hline$L P$ & 2925 & 1930 & 2023 & 2005 & 1970 & & & 1920 \\
\hline M1 & & & & & & & & 2445 \\
\hline SA & 3035 & 3060 & 3130 & 3020 & 2955 & & & 3020 \\
\hline 81 & & & 3378 & 3210 & 3098 & & & 3220 \\
\hline 92 & 3280 & 3425 & 3490 & 3470 & 3375 & & & 3410 \\
\hline \$3 & 3730 & 3880 & 3945 & 3710 & & & 1150 & 3925 \\
\hline 94 & 1165 & 4250 & 1260 & 3930 & 3745 & & 1435 & 1160 \\
\hline 95 & & 4860 & & & & & & 1670 \\
\hline 96 & & 5135 & & & & & & 4815 \\
\hline 87 & & & & & & & & 5295 \\
\hline 88 & & & & 5280 & & & & 5305 \\
\hline 89 & & & & & & & & 6020 \\
\hline HL & & & & & & & & 6220 \\
\hline $\mathrm{TB}$ & 1765 & & & & 5447 & & 5170 & \\
\hline To & 4815 & 5285 & 1310 & 5330 & 5497 & 5170 & 5220 & 6270 \\
\hline
\end{tabular}




\begin{tabular}{|c|c|c|c|c|c|c|c|c|}
\hline & 5270 & 3271 & 5273 & 5274 & 5273 & 5276 & 5277 & $\$ 278$ \\
\hline REP , EL. & 0 & 0 & 0 & 0 & 0 & 0 & 0 & 0 \\
\hline \multicolumn{9}{|c|}{ 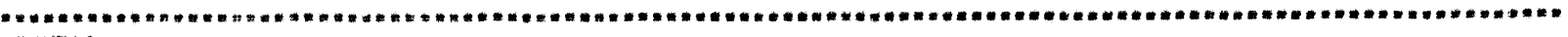 } \\
\hline \multicolumn{9}{|c|}{ SYMaOL } \\
\hline PL & & & & & & 790 & 775 & \\
\hline MP & 1322 & 1345 & 1198 & 1410 & 1445 & 1310 & 1270 & 1320 \\
\hline LP & 1950 & & 1860 & 1932 & 2130 & 1790 & 1668 & 1780 \\
\hline$M i$ & & 2190 & 2196 & & & 2153 & 2105 & 2195 \\
\hline $8 A$ & 2950 & & 3000 & 3042 & 3070 & 2095 & & \\
\hline 81 & & & 3340 & & & 3195 & & \\
\hline 32 & 3348 & & 3585 & 3245 & 3235 & 3160 & 3315 & 2935 \\
\hline 81 & 3675 & 3600 & 4045 & 3005 & 3602 & 3720 & & 3702 \\
\hline 84 & 1955 & 3890 & 1480 & 4255 & 3980 & 3960 & & 1902 \\
\hline 98 & & & & 5165 & & & & 1495 \\
\hline Ts & 1636 & & 5419 & & & 4327 & 3515 & \\
\hline $\mathrm{TD}$ & 4686 & 10000 & 5465 & 5215 & 4030 & 4377 & 3565 & 4545 \\
\hline
\end{tabular}

\begin{tabular}{|c|c|c|c|c|c|c|c|c|}
\hline & 5279 & 5261 & 5282 & 5283 & 5284 & 5285 & 5286 & $5286-8 T 1$ \\
\hline REF, BL. & 0 & 0 & 0 & 0 & 0 & 0 & 0 & 0 \\
\hline \multirow{2}{*}{\multicolumn{9}{|c|}{ SYMBOL }} \\
\hline & & & & & & & & \\
\hline $\mathrm{PL}$ & & & & & & 843 & & \\
\hline MP & & 1160 & 1175 & & 1355 & 1574 & & \\
\hline L.P & 1553 & 1720 & 1715 & 2605 & & 1950 & & \\
\hline$M I$ & & 2255 & 2235 & & & & & \\
\hline $\mathbf{S A}$ & 2715 & & & & & & & \\
\hline $\mathbf{8 1}$ & & 2960 & 2910 & & & & & \\
\hline 92 & 2885 & 1162 & 3115 & & & & & \\
\hline s) & 3495 & 1678 & 3625 & & & & & \\
\hline 84 & & 4425 & 3975 & & & & & \\
\hline 95 & & & 1625 & & & & & \\
\hline 88 & & 1630 & & & & & & \\
\hline $\mathrm{Ts}$ & 4060 & & & 935 & 3420 & & & \\
\hline BS & & & & & 4760 & & & \\
\hline TD & 1110 & 1680 & 4675 & 2655 & 4810 & 2000 & 10 & 10 \\
\hline
\end{tabular}

\begin{tabular}{|c|c|c|c|c|c|c|c|c|}
\hline & 5267 & $528 \mathrm{~B}$ & 5289 & 5290 & 5291 & 5292 & 5291 & $5293.8 T 1$ \\
\hline REF, BL。 & 0 & 0 & 0 & 0 & 0 & 0 & 0 & 0 \\
\hline \multirow{2}{*}{\multicolumn{9}{|c|}{ 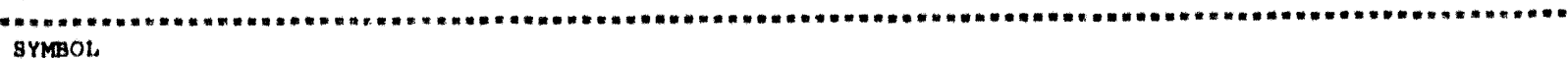 }} \\
\hline & & & & & & & & \\
\hline$P L$ & 841 & 820 & & 855 & & & 610 & 630 \\
\hline MP & 1396 & & 1405 & 1240 & & 1375 & & \\
\hline LP & 1672 & & 1950 & 1875 & 2110 & 1960 & & 1580 \\
\hline$M i$ & & & & 2675 & 2842 & 2850 & & 2000 \\
\hline SA & & & 3055 & 3000 & 3230 & 3095 & & \\
\hline 81 & & & & & 3485 & & & 2595 \\
\hline 82 & & & 3295 & & 3753 & 3147 & & 2830 \\
\hline 53 & & & 1835 & & 4348 & 3695 & & 3250 \\
\hline 81 & & & 4250 & & 1715 & 4275 & & \\
\hline 85 & & & & & 5385 & & & \\
\hline 96 & & & & & 5540 & & & \\
\hline 57 & & & & & 6012 & & & \\
\hline 88 & & & 5095 & & 6235 & 5666 & & \\
\hline 59 & & & & & 6870 & 6370 & & \\
\hline HL & & & & & 7370 & 6762 & & \\
\hline $\mathbf{F F}$ & & & & & 7675 & 7070 & & \\
\hline mo & & & & & 8130 & 7330 & & \\
\hline $\mathrm{CH}$ & & & & & & 7725 & & \\
\hline $\mathrm{Tg}$ & & & & & 8415 & & 1400 & 1700 \\
\hline TO & 1922 & 870 & 5145 & 3050 & 8465 & 7775 & 10000 & 10000 \\
\hline
\end{tabular}


BAYOU CHOCTAN OBOLOOICAL CHARACTBRTZATION

SUMAARY OF WRLL LOO INTBRPRETATIONS

MBLL NAME

\begin{tabular}{|c|c|c|c|c|c|c|c|c|}
\hline REF. RL. & $\begin{array}{r}5295 \\
0\end{array}$ & $\begin{array}{r}3296 \\
0\end{array}$ & $\begin{array}{r}5297 \\
0\end{array}$ & 5299 & $\begin{array}{r}5301 \\
0\end{array}$ & $\begin{array}{r}3302 \\
0\end{array}$ & $\begin{array}{r}5303 \\
0\end{array}$ & 3304 \\
\hline sYMBot & & & & & . & 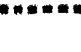 & $m \cdots$ & an. \\
\hline PL & 780 & & & & 919 & & & \\
\hline MP & & & & & 1460 & 1720 & & \\
\hline LP & & 2255 & 2170 & & 2145 & 2325 & 2330 & 2090 \\
\hline Mi & 2770 & & 2045 & & 3040 & 3130 & 3068 & 2913 \\
\hline SA & & & 3303 & & 3430 & 3460 & 3467 & 3450 \\
\hline 81 & & & 3670 & & 3500 & 3660 & 3660 & 3705 \\
\hline s2 & & & 1130 & & 3085 & 3923 & 3943 & 3095 \\
\hline 83 & & & 1648 & & 1660 & 1713 & 1650 & 1528 \\
\hline 84 & & & 3055 & & 4930 & 1973 & 4920 & 1945 \\
\hline 85 & & & & & 5410 & 5424 & 5367 & 3310 \\
\hline 86 & & & & & 9385 & 5587 & 5310 & 3490 \\
\hline 87 & & & & & 5970 & 6073 & 5980 & 5983 \\
\hline 88 & & & & & 6350 & 6320 & 6450 & 6325 \\
\hline 89 & & & & & 7200 & 7360 & 7205 & 7263 \\
\hline HL & & & & & 7585 & 1863 & 7610 & 0195 \\
\hline$F F$ & & & & & 7950 & 8160 & 8005 & \\
\hline Mo & & & & & 0170 & 8382 & 8223 & \\
\hline $\mathrm{CH}$ & & & & & 0393 & 8571 & 0605 & \\
\hline $\mathrm{Mr}$ & & & & & 8592 & & & \\
\hline BM & & & & & 9105 & & & \\
\hline $\mathrm{NB}$ & & & & & 9568 & & & \\
\hline TS & 905 & 1267 & & 1630 & & & & \\
\hline BS & 1221 & & & 1270 & & & & \\
\hline To & 2820 & 2105 & 5105 & 3760 & 9610 & 8621 & 0655 & 8205 \\
\hline
\end{tabular}

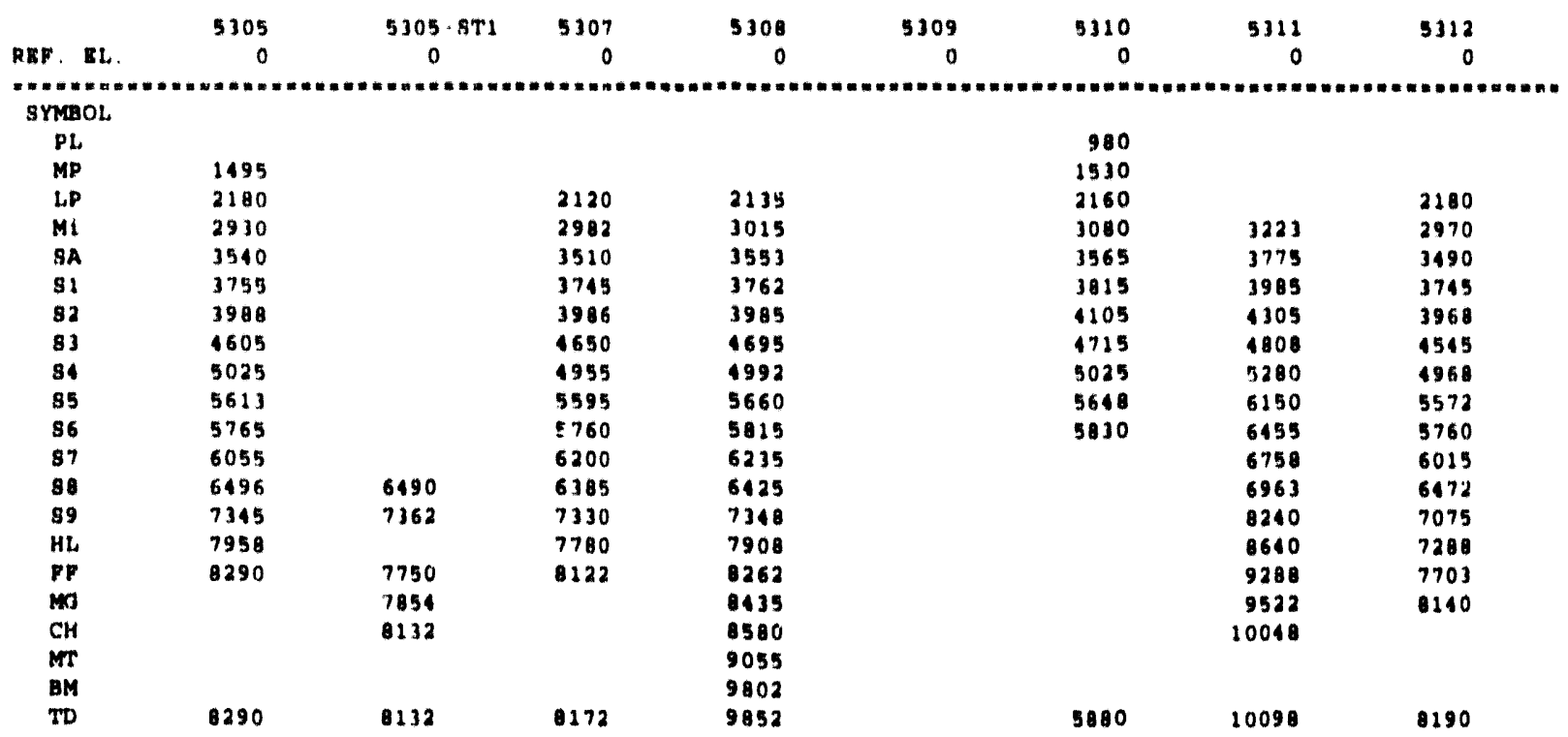




\begin{tabular}{|c|c|c|c|c|c|c|c|c|}
\hline & 5313 & 5314 & 5315 & 5316 & 3317 & 3318 & 8319 & $5 \mathbf{3 2 0}$ \\
\hline REF， BL. & 0 & 0 & 0 & 0 & 0 & 0 & 0 & 0 \\
\hline \multicolumn{9}{|c|}{ 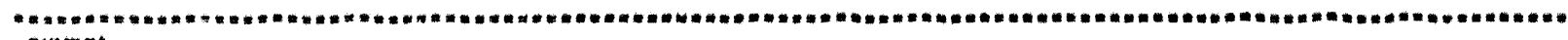 } \\
\hline \multicolumn{9}{|c|}{ SYMBOt. } \\
\hline Mi & 3260 & 3040 & & & & & & \\
\hline BA & 3495 & 3578 & 3465 & & & & & \\
\hline 81 & 3810 & 3794 & 3670 & & & & & \\
\hline 82 & 1155 & 4063 & 3955 & & & & & \\
\hline 81 & 4665 & 1611 & 1580 & & & & & \\
\hline 94 & 5055 & 5144 & 5020 & & & & & \\
\hline 85 & 5895 & $579 B$ & 5658 & & & & & \\
\hline 56 & 6319 & 6149 & & & & & & \\
\hline 87 & 6515 & & 6028 & & & & & \\
\hline 88 & 6704 & 6489 & 6405 & & & & & \\
\hline 89 & 7802 & 7340 & 7225 & & & & & \\
\hline HL & 0458 & 0040 & 7640 & & & & & \\
\hline $\mathbf{F}$ & 0945 & 9470 & 0042 & & & & & \\
\hline wa & 9120 & & 8250 & & & & & \\
\hline $\mathrm{CH}$ & 9690 & & 8825 & & & & & \\
\hline $\mathbf{M T}$ & 10202 & 8705 & 9110 & & & & & \\
\hline BM & 10970 & 9500 & 9590 & & & & & \\
\hline $\mathrm{MB}$ & 11445 & 10220 & & & & & & \\
\hline $\mathrm{Ts}$ & & & & 650 & 661 & 683 & 920 & 675 \\
\hline \multirow[t]{2}{*}{$T$} & 11495 & $102 \% 0$ & 9640 & 1860 & 1952 & 1850 & 970 & 1910 \\
\hline & 5321 & 5322 & 5323 & 5324 & 5325 & 5326 & 5327 & $\$ 328$ \\
\hline REF, BL. & 0 & 0 & 0 & 0 & 0 & 0 & 0 & 0 \\
\hline \multirow{2}{*}{\multicolumn{9}{|c|}{ 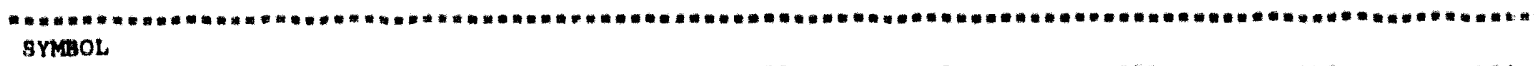 }} \\
\hline & & & & 085 & 840 & 85s & 050 & 914 \\
\hline MP & & & & 1420 & 1275 & 1340 & 1351 & \\
\hline tip & & & & 2040 & 1995 & 1975 & 2076 & 2105 \\
\hline Mi & & & & 2910 & 2905 & & 2940 & 3015 \\
\hline gA & & & & 3170 & 1170 & 1178 & 3119 & \\
\hline 21 & & & & 3410 & 1360 & 3425 & 1495 & 3565 \\
\hline 82 & & & 3850 & 1660 & 3698 & 3725 & 3710 & 3095 \\
\hline 93 & & & 4265 & 1590 & 1100 & & 1455 & 1906 \\
\hline 84 & & & & 4840 & 4716 & & 1810 & 4027 \\
\hline 85 & & & & 5390 & 5280 & 3052 & 5160 & 5409 \\
\hline 96 & & & 5455 & 5549 & 5590 & 3410 & 5522 & 5565 \\
\hline 87 & & & & 6005 & $58 B 5$ & 5905 & 5788 & 5055 \\
\hline 80 & & & 5975 & 6085 & 6040 & 6035 & 6210 & 6300 \\
\hline 99 & & & & 6975 & 6920 & 6975 & 6971 & 7210 \\
\hline $\mathrm{HL}$ & & & & 7162 & 7118 & 7390 & 7290 & 7600 \\
\hline $\boldsymbol{F}$ & & & & 1792 & 7700 & 1710 & 7640 & 7960 \\
\hline$m$ & & & & 0192 & & & 7810 & 1020 \\
\hline CII & & & & 0102 & & & 0192 & 0178 \\
\hline$m r$ & & & & 0645 & & & & \\
\hline BM & & & & 8940 & & & & \\
\hline Ts & 681 & 692 & 2271 & 9040 & & & & \\
\hline \multirow[t]{2}{*}{$T D$} & 4355 & 742 & 6025 & 9090 & 7750 & 7700 & 0242 & 8420 \\
\hline & 5329 & 5310 & 5331 & 5332 & 3315 & 5316 & 3117 & 5119 \\
\hline RRF EL, & 0 & 0 & 0 & 0 & 0 & 0 & 0 & 0 \\
\hline \multicolumn{9}{|l|}{ 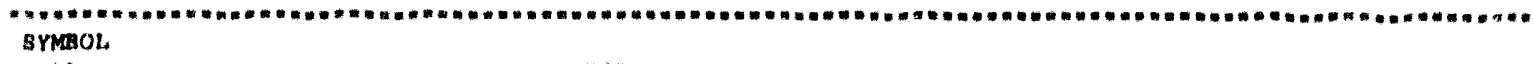 } \\
\hline PL. & & & 760 & & & & & \\
\hline MP & & & 1466 & & & & & \\
\hline LP & 2120 & 2120 & 1970 & & & & 2160 & 2051 \\
\hline$M i$ & 1025 & 1002 & 2795 & 2515 & 2695 & & 2940 & 2810 \\
\hline SA & 3120 & 1280 & 3296 & 2625 & 1015 & 2855 & 1445 & 1240 \\
\hline 91 & 1518 & 3490 & 3410 & 1062 & 1278 & & 1690 & 3565 \\
\hline 92 & 1895 & 3940 & 3692 & 3405 & & & 3898 & 3812 \\
\hline 83 & 4820 & 4780 & 1280 & 1008 & & & 1540 & 1122 \\
\hline 94 & 1964 & 4970 & 4828 & 4248 & & & 4900 & 4295 \\
\hline 85 & 3190 & 5538 & 5155 & & & & 5592 & 5414 \\
\hline 86 & 5580 & 5723 & 5510 & & & & 5785 & 5546 \\
\hline 87 & 6146 & & & & & & 6054 & 5005 \\
\hline 58 & 6275 & 6200 & 6025 & 5148 & & & & 6250 \\
\hline 39 & 7210 & 7180 & 6978 & 6030 & & & & 7002 \\
\hline HL & 7602 & 7695 & 7167 & & & & & \\
\hline $\mathbf{P F}$ & 8045 & 7965 & 7645 & & & & & 7405 \\
\hline MO & 8315 & 8155 & & & & & & \\
\hline $\mathrm{CH}$ & 8785 & 8360 & & & & & & \\
\hline $\mathrm{TS}$ & & & & 991 & 940 & & & \\
\hline BS & & & & 1700 & 1640 & & & \\
\hline$T D$ & 8835 & 8410 & 7695 & 6080 & 3328 & 2903 & 6104 & 7535 \\
\hline
\end{tabular}




\begin{tabular}{|c|c|c|c|c|c|c|c|c|}
\hline & 5340 & 5341 & 5342 & 5344 & 5345 & 5346 & 5348 & 5349 \\
\hline REF. BL. & 0 & 0 & 0 & 0 & 0 & 0 & 0 & 0 \\
\hline \multirow{2}{*}{\multicolumn{9}{|c|}{ 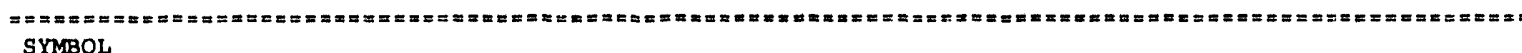 }} \\
\hline & \\
\hline PL & & 730 & 865 & & & & & \\
\hline$M P$ & & 1385 & 1440 & & & & & \\
\hline LP & 2060 & 1920 & 2125 & 2115 & & & & \\
\hline Mi & 2770 & 2640 & 2830 & 2920 & & & & \\
\hline SA & 3185 & 3098 & 3285 & 3442 & & 3210 & & \\
\hline $\mathbf{s 1}$ & 3532 & 3380 & 3660 & 3578 & & 3365 & & \\
\hline S2 & 3728 & 3584 & 3860 & 3878 & & 3810 & & \\
\hline s3 & 4412 & 4210 & 4575 & 4565 & & & & \\
\hline S4 & 4870 & 4712 & 4955 & 4886 & & 4386 & 4765 & \\
\hline S5 & 5483 & 5350 & 5552 & 5425 & & & & \\
\hline S6 & 5635 & 5530 & 5775 & 5592 & & & & \\
\hline 57 & 5910 & 5780 & 6115 & 5856 & & & & \\
\hline S8 & 6390 & 6250 & 6330 & 6292 & & & 5875 & 5135 \\
\hline 59 & 6948 & 6835 & 7245 & 7276 & & & & \\
\hline HL & 7120 & 6972 & 7705 & 7475 & & & 7410 & \\
\hline FF & 7673 & 7250 & 7945 & 7745 & & & & \\
\hline MG & 8000 & & & 7970 & & & & \\
\hline $\mathrm{CH}$ & & & & 8302 & & & & \\
\hline TS & & & & & 815 & 2850 & 694 & 793 \\
\hline BS & & & & & 4669 & 2980 & & 3155 \\
\hline \multirow[t]{2}{*}{$\mathrm{TD}$} & 8050 & 7300 & 7995 & 10000 & 4719 & 4436 & 7460 & 5185 \\
\hline & 5350 & 5351 & 5352 & 5353 & 5354 & 5355 & 5357 & 5358 \\
\hline REF. EL. & 0 & 0 & 0 & 0 & 0 & 0 & 0 & 0 \\
\hline \multicolumn{9}{|c|}{ 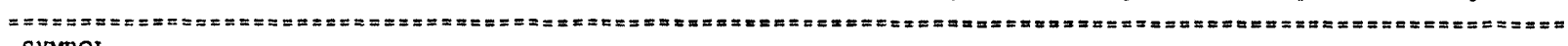 } \\
\hline \multicolumn{9}{|c|}{ SYMBOL } \\
\hline PL & & 735 & & & & & & \\
\hline MP & & & & & & & & 1500 \\
\hline LP & & & & & & & 2205 & 2195 \\
\hline Mi & & & & & & & 3362 & \\
\hline SA & & & 3000 & & & & 3535 & \\
\hline S1 & & 3015 & 3425 & & & & & \\
\hline s2 & 3255 & 3352 & 3590 & & & & 4185 & \\
\hline 53 & 3750 & 3758 & 4201 & & & & 4700 & \\
\hline S4 & 4135 & 4260 & 4720 & & & & 5253 & \\
\hline S5 & & & 5068 & & & & 5595 & \\
\hline S6 & & & 5278 & & & & 5995 & \\
\hline s7 & & & & & & & 6208 & \\
\hline s8 & 5360 & 5485 & & & & 7108 & 6323 & \\
\hline s9 & & & & & & 7432 & 7222 & \\
\hline HL & & & & & & 8125 & 7460 & \\
\hline $\mathrm{FF}$ & & & & & & & 8042 & \\
\hline MG & & & & & & & 8290 & \\
\hline $\mathrm{CH}$ & & & & & & & 8772 & \\
\hline TS & 850 & 870 & 735 & 760 & 697 & & & \\
\hline BS & 3000 & & & & & & & \\
\hline \multirow[t]{2}{*}{$\mathrm{TD}$} & 5410 & 5535 & 5328 & 810 & 747 & 8175 & 8822 & 2245 \\
\hline & 5359 & 5360 & 5361 & 5362 & 5363 & 5364 & 5365 & 5366 \\
\hline REF. EL. & 0 & 0 & 0 & 0 & & 0 & 0 & 0 \\
\hline \multirow{2}{*}{\multicolumn{9}{|c|}{ 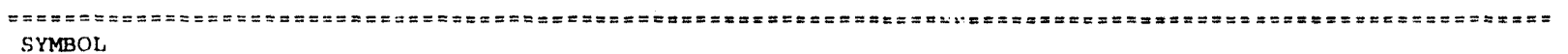 }} \\
\hline & & & \multirow{2}{*}{\multicolumn{6}{|c|}{$\begin{array}{l}\text { SYMBOL } \\
\text { MP }\end{array} \quad 3425$}} \\
\hline MP & 3425 & & & & & & & \\
\hline LP & 2105 & & & & & & 2105 & \\
\hline $\mathrm{Mi}$ & & & & 2445 & & 2752 & 2960 & 2800 \\
\hline$S A$ & & & & & & 3130 & 3305 & 3040 \\
\hline$s 1$ & & & & 3035 & & 3440 & 3505 & \\
\hline $\mathrm{s} 2$ & & & 2950 & 3290 & 2895 & 3650 & 3905 & 3210 \\
\hline s3 & & & & 3905 & 3620 & 4160 & 4806 & 4030 \\
\hline 54 & & & & 4290 & & & 4941 & 4355 \\
\hline S5 & & & & & & 4840 & 5430 & 4940 \\
\hline S6 & & & & & & 5060 & 5585 & \\
\hline 57 & & & & & & 5555 & 6160 & \\
\hline s8 & & & & & & 5955 & 6295 & 5705 \\
\hline s9 & & & & & & 6645 & & \\
\hline HL & & & & & & 7057 & 7592 & \\
\hline FF & & & & & & 7495 & 8032 & \\
\hline $\mathrm{TS}$ & & 670 & 2200 & & & & & \\
\hline $\mathrm{TD}$ & 2155 & 720 & 10000 & 4340 & 3670 & 7545 & 8082 & 5755 \\
\hline
\end{tabular}




\begin{tabular}{|c|c|c|c|c|c|c|c|c|}
\hline & 5367 & 5368 & 5369 & 5370 & $5370 . \mathrm{ST} 1$ & 5372 & 5373 & $5373-\mathrm{ST1}$ \\
\hline REF, EL. & 0 & 0 & 0 & 0 & 0 & 0 & 0 & 0 \\
\hline \multicolumn{9}{|c|}{ 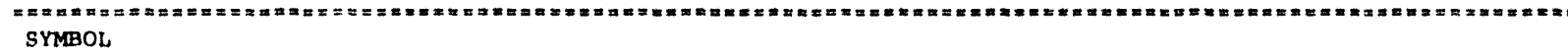 } \\
\hline $\begin{array}{l}\text { SYMBOL } \\
\text { LP }\end{array}$ & 2365 & & & & & & & \\
\hline $\mathrm{Mi}$ & 3158 & & & & & & & \\
\hline SA & 3463 & & & & & & & \\
\hline S1 & 3696 & & & & & & & \\
\hline $\mathbf{S 2}$ & 4000 & & & & & & & 3428 \\
\hline $\mathbf{s 3}$ & 4815 & & & & & & & \\
\hline 54 & 5098 & & & & & & & \\
\hline 55 & 5601 & & & & & & & \\
\hline \$6 & 5802 & & & & & & & \\
\hline 57 & 6086 & & & & & & & \\
\hline S8 & 6553 & & & & & & & \\
\hline 59 & 7598 & & & & & & & \\
\hline HL & 8096 & & & & & & & \\
\hline FF & 8301 & & & & & & & \\
\hline TS & & 2088 & 667 & & & 718 & & 4225 \\
\hline BS & & 2212 & & & & 4660 & & \\
\hline \multirow[t]{2}{*}{ TD } & 8351 & 2262 & 2740 & 10000 & 10000 & 10000 & 50 & 4275 \\
\hline & 5375 & 5376 & $5376-$ ST1 1 & 5378 & 5379 & 5380 & $5380-\mathrm{ST} 1$ & $5380-5 T 2$ \\
\hline REF. EL. & 0 & 0 & 0 & 0 & 0 & 0 & 0 & 0 \\
\hline \multicolumn{9}{|c|}{ 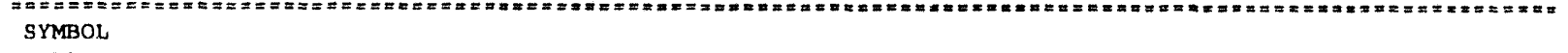 } \\
\hline PL & & & & & & 835 & & \\
\hline MP & & & & & & 1395 & & \\
\hline LP & & & & & & 2095 & 2060 & \\
\hline Mi & & & & & & & 2855 & \\
\hline SA & & & & & 2748 & & & \\
\hline$S 1$ & & & & 3160 & & & 3452 & \\
\hline $\mathbf{S} 2$ & 3312 & & & 3350 & 3510 & & 3625 & \\
\hline 53 & 3670 & & 3675 & 3840 & 3895 & & & \\
\hline 54 & & & 4060 & 4200 & 4535 & & & \\
\hline S5 & & & 4895 & 4540 & & & & \\
\hline S6 & & & & 4860 & & & & \\
\hline S7 & & & & 5295 & & & & \\
\hline 58 & & & & 5540 & & & & \\
\hline HL & & & & & 6630 & & & \\
\hline TS & 852 & 823 & & 735 & 805 & & & \\
\hline BS & 2894 & & & 2850 & 1988 & & & \\
\hline TD & 3720 & 10000 & 4895 & 5590 & 6680 & 10000 & 3625 & 10000 \\
\hline & 5383 & 5384 & 5385 & 5387 & 5388 & 5389 & 5390 & 6001 \\
\hline REF . EL . & 0 & 0 & 0 & 0 & 0 & 0 & 0 & 0 \\
\hline \multicolumn{9}{|c|}{ 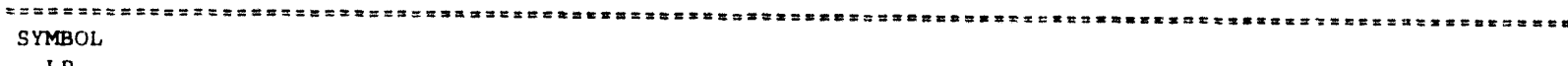 } \\
\hline$L P$ & & & & & & & & 2260 \\
\hline $\mathrm{Mi}$ & & & & & & & & 3128 \\
\hline SA & & & & & & & & 3525 \\
\hline S1 & & & & & & & & 3778 \\
\hline S2 & & & & & & & & 1033 \\
\hline S3 & & & & & & & & 4805 \\
\hline S4 & & & & & & & & 5301 \\
\hline 55 & & & & & & & & 5760 \\
\hline S6 & & & & & & & & 6198 \\
\hline 57 & & & & & & & & 6490 \\
\hline 58 & & & & & & & & 6630 \\
\hline 59 & & & & & & & & 7068 \\
\hline HL & & & & & & & & 7678 \\
\hline FF & & & & & & & & \\
\hline TS & & & 660 & 0 & 679 & & & \\
\hline TD & & & 710 & 740 & 729 & & & 10000 \\
\hline
\end{tabular}




\begin{tabular}{|c|c|c|c|c|c|c|c|c|}
\hline & 6101 & 6103 & 6104 & 6105 & 6106 & 6107 & 6108 & 6110 \\
\hline REF. EL. & 0 & 0 & 0 & 0 & 0 & 0 & 0 & 0 \\
\hline \multicolumn{9}{|l|}{$\begin{array}{c}=\Rightarrow=x=2=\Rightarrow= \\
\text { SYMBOL }\end{array}$} \\
\hline PL & 918 & & 985 & & & & & \\
\hline MP & 1425 & 1535 & 1435 & & & & & \\
\hline LP & 2060 & 2165 & 2070 & 2105 & 2145 & 2120 & 2220 & 2198 \\
\hline Mi & 2925 & 2960 & 2942 & 3000 & 3032 & 2985 & 3055 & 2858 \\
\hline SA & 3260 & 3560 & 3308 & 3350 & 3460 & 3395 & 3488 & 3432 \\
\hline 53 & 3525 & 3885 & 3645 & 3650 & 3790 & 3710 & 3885 & \\
\hline S2 & 3755 & 4185 & 3808 & 3915 & 4118 & 3935 & 4165 & 4015 \\
\hline s3 & 4400 & 4848 & 1605 & 4520 & 4760 & 4418 & 4808 & 4630 \\
\hline S4 & 4820 & 5240 & 5155 & 5030 & 5150 & 4735 & 5228 & 5055 \\
\hline S5 & & 6040 & 5778 & 5574 & 5995 & & & 5750 \\
\hline s6 & & 6410 & 6172 & & 6138 & & & 5965 \\
\hline S7 & & & & 6025 & & 6052 & 6450 & 6395 \\
\hline s8 & & 6820 & & 6175 & 6396 & 6214 & 6772 & 6502 \\
\hline S9 & & 7905 & & & 6990 & 6910 & & 7635 \\
\hline HL & & 8615 & & 7060 & 7148 & 7460 & & 8218 \\
\hline $\mathbf{F F}$ & & 8740 & & 7410 & 7845 & 8000 & & 8870 \\
\hline MG & & 9005 & & & & & & \\
\hline $\mathrm{CH}$ & & 9340 & & & & & & \\
\hline TS & & & 6940 & 7885 & & & 7570 & \\
\hline \multirow[t]{2}{*}{$T D$} & 4870 & 9390 & 6990 & 7935 & 7895 & 8050 & 7620 & 8920 \\
\hline & 6111 & 6112 & 6151 & 6152 & 6153 & 6154 & 6155 & 8201 \\
\hline REF . EL. & 0 & 0 & 0 & 0 & 0 & 0 & 0 & 0 \\
\hline \multicolumn{9}{|l|}{$\begin{array}{l}x= \pm x=x=x \\
\text { SYMBOL }\end{array}$} \\
\hline PL & & & & & & & & 970 \\
\hline MP & & & & & & & & 1385 \\
\hline LP & 2150 & & 2270 & & 2220 & 2195 & & 2098 \\
\hline$M i$ & 3090 & 2935 & 3058 & 3010 & 3320 & 3012 & 3098 & 3066 \\
\hline SA & 3475 & 3350 & 3625 & 3615 & 3648 & 3605 & 3452 & \\
\hline s1 & 3798 & 3638 & 4035 & 3850 & 3932 & & 3795 & 3722 \\
\hline$s 2$ & 4076 & 3945 & 4290 & 4205 & 4173 & 3964 & 4277 & 4085 \\
\hline 93 & 4762 & 4525 & 4902 & 4910 & 4665 & 4640 & 4712 & 4690 \\
\hline 34 & 4980 & 4925 & 5425 & 5328 & 5073 & 5014 & 5250 & 5122 \\
\hline 35 & 5720 & 5710 & 6295 & 6090 & 5840 & 5815 & 6050 & 5965 \\
\hline 86 & 5986 & 5940 & & & 6078 & 6070 & 6352 & 6185 \\
\hline 57 & 6302 & 6363 & 6705 & 6135 & 6478 & 6252 & & 6572 \\
\hline s8 & 6498 & 6465 & 6805 & 6590 & 6638 & 6417 & 6543 & 6756 \\
\hline s9 & 7478 & 7395 & 7950 & 7785 & 7690 & 7565 & 7656 & 7806 \\
\hline HL & 7872 & 7908 & 8425 & 8220 & 8192 & 8002 & 8155 & 8302 \\
\hline $\mathbf{F F}$ & & 8435 & 8760 & 8916 & 8715 & 8425 & 8675 & 8780 \\
\hline MG & & 8710 & 9025 & & 8910 & 8650 & 8880 & 8992 \\
\hline $\mathrm{CH}$ & & 9175 & 9315 & & 9137 & 8890 & & 9333 \\
\hline MT & & 9400 & 9520 & 9205 & 9330 & 9060 & 9112 & 9400 \\
\hline $\mathrm{BM}$ & & & 9958 & 9990 & 10025 & 9630 & 9842 & 9980 \\
\hline NB & & & & & 1.0322 & & & \\
\hline \multirow[t]{2}{*}{$T D$} & 7922 & 9450 & 10048 & 10040 & 10372 & 9680 & 9892 & 10030 \\
\hline & 9991 & 9992 & 9993 & 9994 & 9995 & 9996 & & \\
\hline REF . BL. & 0 & 0 & 0 & 0 & 0 & 0 & & \\
\hline \multicolumn{9}{|c|}{ 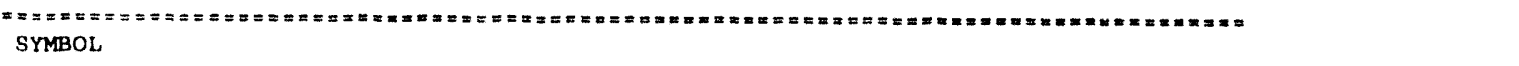 } \\
\hline PL & 9991.019 & 9992.019 & 9993.019 & 9994.019 & 9995.019 & 9996.019 & & \\
\hline MP & 9991.03 & 9992.03 & 9993.03 & 9994.03 & 9995.03 & 9996.03 & & \\
\hline LP & 9991.04 & 9992.04 & 9993.04 & 9994.04 & 9995.04 & 9996.04 & & \\
\hline Mi & 9991.05 & 9992.05 & 9993.05 & 9994.05 & 9995.05 & 9996.05 & & \\
\hline SA & 9991.059 & 9992.059 & 9993.059 & 9994.059 & 9995.059 & 9996.059 & & \\
\hline S1 & 9991.071 & 9992.071 & 9993.071 & 9994.071 & 9995.011 & 9996.071 & & \\
\hline s2 & 9991.08 & 9992.08 & 9993.08 & 9994.08 & 9995.08 & 9996.08 & & \\
\hline s3 & 9991.09 & 9992.09 & 9993.09 & 9994.09 & 9995.09 & 9996.09 & & \\
\hline S4 & 9991.099 & 9992.099 & 9993.099 & 9994.099 & 9995.099 & 9996.099 & & \\
\hline S5 & 9991.111 & 9992.111 & 9993.111 & 9994.111 & 9995.111 & 9996.111 & & \\
\hline s6 & 9991.12 & 9992.12 & 9993.12 & 9994.12 & 9995.12 & 9996.12 & & \\
\hline S7 & 9941.13 & 9992.13 & 9993.13 & 9994.13 & 9995.13 & 9996.13 & & \\
\hline 58 & 9991.139 & 9992.139 & 9993.139 & 9994.139 & 9995.139 & 9996.139 & & \\
\hline s9 & 9991.151 & 9992.151 & 9993.151 & 9994.151 & 9995.151 & 9996.151 & & \\
\hline HL & 9991.16 & 9992.16 & 9993.16 & 9994.16 & 9995.16 & gr 6.16 & & \\
\hline$F F$ & 9991.17 & 9992.17 & 9993.17 & 9994.17 & 9995.17 & $99,6.17$ & & \\
\hline MO & 9991.18 & 9992.18 & 9993.18 & 9994.18 & 9995.18 & 9996.18 & & \\
\hline $\mathrm{CH}$ & 9991.191 & 9992.191 & 9993.1 .91 & 9994.191 & 9995.191 & 9996.191 & & \\
\hline$M r$ & 9991.2 & 9992.2 & 9993.2 & 9994.2 & 9995.2 & 9996.2 & & \\
\hline $\mathrm{BM}$ & 9991.21 & 9992.21 & 9993.21 & 9994.21 & 9995.21 & 9996.21 & & \\
\hline NB & 9991.22 & 9992.22 & 9993.22 & 9994.22 & 9995.22 & 9996.22 & & \\
\hline TS & 9991.231 & 9992.231 & 9993.231 & 9994.231 & 9995.231 & 9996.231 & & \\
\hline BS & 9991.24 & 9992.24 & 9993,24 & 9994.24 & 9995.24 & 9996.24 & & \\
\hline$T D$ & 9991.26 & 9992.26 & 9993.26 & 9994.26 & 9995.26 & 9996.26 & & \\
\hline
\end{tabular}


File, 6113

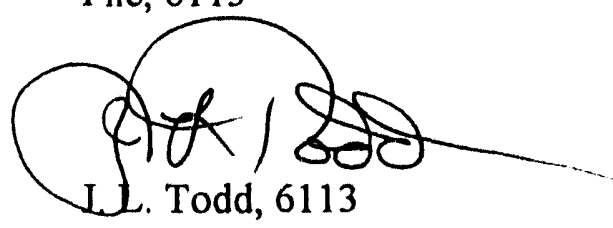

Albuquerque, New Mexico 87185

\section{BC Cavern 4 -- Comparison of 1992, 1980 and 1963 Cavern Sonars}

We have revisited the question of Bayou Choctaw Cavern 4 stability as part of the effort to update the geological site characterization of the Bayou Choctaw Site. The results of the August 1992 sonar survey have been compared with the surveys conducted in 1980 and 1963. In summary, we find that there is no convincing evidence to suggest that significant changes have occurred since 1980. Indicated differences in cavern volume and shape between the 1980 and 1992 survey are within the uncertainties normally expected from cavern sonar surveys.

Comparisons of the general shape of the cavern in 1963, 1980 and 1992 show the following:

1. There is no evidence of continued enlargement of the upper 350 feet of the cavern during the period of 1980 through 1992 (the cavern roof is at about - 650 feet). This is in contrast to the large increase in size noted between 1963 and 1980. This upper portion of the cavern is most critical to stability since there is evidence that the cavern roof is in caprock.

2. At several depths, the 1992 survey shows that the range to the cavern wall is about 100 feet less than that seen in the 1980 survey. This seems to agree more closely with the 1963 survey than with the 1980 survey. The discrepancy is probably due to changes in sonar technology and to variability in interpretation of the logs. Creep of this magnitude would not occur over a 12-year period in a shallow cavern like BC 4 so it is unlikely that the cavern wall moved inward 100 feet between 1980 and 1992.

3. From about - 1000 feet to - 1400 feet, comparison of the 1980 and 1993 surveys shows no consistent trend with some radii larger and some smaller (by as much as about 50 feet). However, the general cavern shape is unchanged. Again, the difference is attributed to the variability in sonar logging technique.

4. The bottom portion of the cavern and the total depth are essentially unchanged from the 1980 survey. 
One way of graphically showing the similarity between the two surveys is to calculate an effective radius from the incremental cavern volume reported at each survey station.

When presented as a function of depth, this type of plot represents a symmetrical cavern having the same vertical volume distribution as the real cavern. The attached figure shows an overlay of the profiles for the 1980 and 1992 surveys. The difference between the two profiles is generally less than 5 percent and is comparable to the advertised sonar survey accuracy. We again conclude that the surveys, taken about twelve years apart, do not show evidence of change.

copy:

J. K. Linn, 6113

J. 'T. Neal, 6113

J. L. Todd, 6113 
CALCULATED RADIUS vs DEPTH

Bayou Choctaw Cavern 4

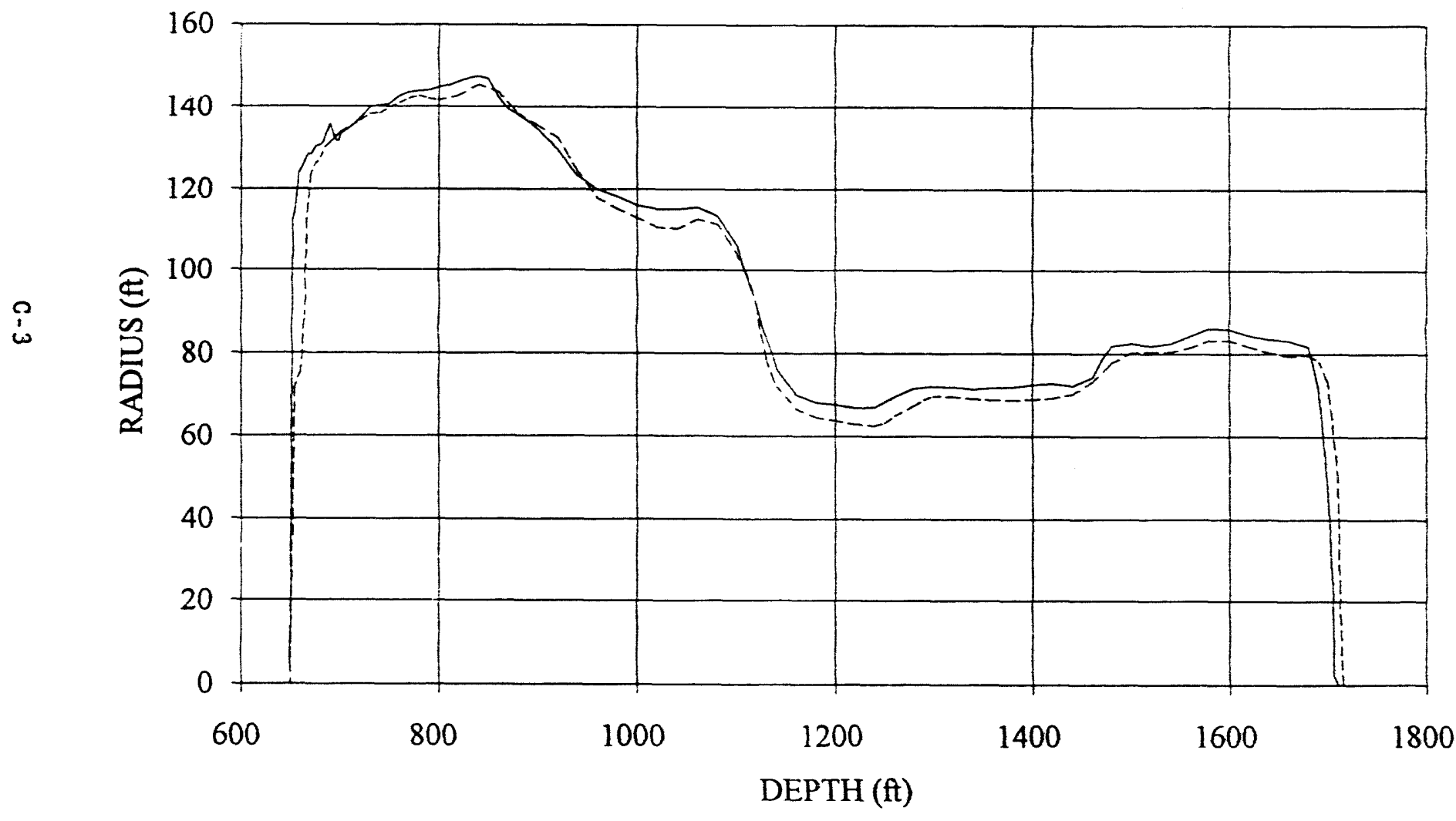

1992 Survey 1980 Survey 


\section{APPENDIX D}

\section{Computer Generated Graphical Representation of Cavern 101, Bayou Choctaw}




\section{APPENDIX D}

Graphical display of Cavern 101, using sonar-derived geometry from digital tapes. View of cavern is rendered in positive relief, whereas actual geometry is negative, i.e., a void. Courtesy P.S. KuhIman, Sandia National Laboratories. 


\section{Distribution}

U.S. DOE SPR PMO (9)

900 Commerce Road East

New Orleans, LA 70123

Attn: J. C. Kilroy, FE 433

J. W. Kunkel, FE 4422

R. E. Myers, FE 4422 (3)

L. J. Rousseau, FE 433

M. W. Smith, FE 4441

TDCS (2)

U.S. Department of Energy (4)

Strategic Petroleum Reserve

1000 Independence Avenue SW

Washington, D.C. 20585

Attn: R. Smith

D. Johnson

D. Buck

H. Giles

DynMcDermott Petroleum Operations (7) 850 South Clearview Parkway

New Orleans, LA 70123

Attn: T. Eyermann

J. McHenry

K. Mills

H. Kubicek

J. Teerling

K. Wynn

L. Eldredge

Acres International Corporation (3) 140 John James Audubon Parkway

Amherst, NY 14228-1180

Attn: B. Lamb

S. Thompson

S. Denzler

Electric Power Research Institute

3412 Hillview Avenue

P. O. Box 10412

Palo Alto, CA 94303

Attn: Bhupen (Ben) Mehta
Solution Mining Research Institute

812 Muriel Street

Woodstock, IL 60098

Attn: H. Fiedelman

Texas Bureau of Economic Geology (3)

University Station, Box X

Austin, TX 78713

Attn: W. L. Fisher

M.P.A. Jackson

S. J. Seni

Joseph D. Martinez

3641 S. Lakeshore Drive

Baton Rouge, LA 70808

T. R. Magorian (8)

133 South Drive

Amherest, NY 14226

L. S. Karably

Law Environmental, Inc.

223 Townpark Dr.

Kennesaw, GA 30144-5599

R. L. Thoms

AGM, Inc.

P.O. Box 10358

College Station, TX 77842

D. H. Kupfer

7324 Menlo Drive \#3

Baton Rouge, LA 70808

A. H. Medley

1716 S. 75th E. Avenue

Tulsa, OK 74112 
Louisiana Geological Survey (3)

University Station, Box G

Baton Rouge, LA 70893

Attn: C. G. Groat

W. J. Autin

Brigid Jensen

Mississippi Department of

Environmental Quality

Office of Geology

Attn: S. Cragin Knox

P. O. Box 20307

Jackson, MS 39289

R. Ginn

Underground Injection Control

Railroad Comm. of Texas

Austin, TX 78711-2967

Injection and Mining Division

Louisiana Office of Conservation

P.O. Box 94275, Capitol Station

Baton Rouge, LA 70804-9275

Joe L. Ratigan

$\mathrm{RE} / \mathrm{SPEC}$, Inc.

3824 Jet Drive

Rapid City, SD 57709

Amoco Production Company

Exploration Dept.

501 West Lake Park Blvd

P.O. Box 3092

Houston, TX 77253

Attn: William Hart

Rudy Begault

The MITRE Corporation

800 Commerce Road East, Suite 201

New Orleans, LA 70123

R G. (Bob) Haley (3)

Union Texas Petroleum

P.O. Box 440

Port Allen, LA 70767
Harry G. Allison

Golden Storage Services, Inc.

711 Louisiana, Suite 1600

Houston, TX 77002

Mr. Ben Knape

Texas Water Commission

$1700 \mathrm{~N}$. Congress Ave.

P.O. Box 13087 Capitol Station

Austin, TX 79811

Prof. Saul Aronow

Department of Geology

Box 10031

Lamar University Station

Beaumont, TX 77710

PB-KBB Inc. (2)

11767 Katy Freeway

P.O. Box 19672

Houston, TX 77224

Attn: Karl M. Looff

B. E. Russell

Bayou Choctaw SPR Site (3)

$60825 \mathrm{Hwy} .1148$

Plaquemine, LA 70764

Attn: M. Slezak

R. Chase

J. Barrington

Big Hill SPR Site

P.O. Box 1270

Winnie, TX 77665

Attn: Jim Perry

Bryan Mound SPR Site

P.O. Box 2276

Freeport, TX 77541'

Attn: H. Bakhtiari 
Weeks Island SPR Site

P.O. Box 434

New Iberia, LA 70560

Attn: M. Bertoldi

West Hackberry SPR Site 1450 Black Lake Road

Hackberry, LA 70645

Attn: P. Hetznecker

\section{Sandia Internal}

6000 D. L. Hartley

6100 R. W. Lynch

6113 J. K. Linn (10)

6113 B. Ehgartner

6113 T. Hinkebein

6113 P. Kuhlman

$6113 \mathrm{~J}$. L. Todd

6113 S. J. Bauer

6113 R.V. Matalucci

6113 J. T. Neal (20)

6116 D. J. Borns

6117 W. R. Wawersik

6117 D. H. Zeuch

6117 J. C. Lorenz

6117 D. S. Preece

6121 F. D. Hansen

7141 Technical Library (5)

7151 Technical Publications

7613-2 Document Processing (for DOE/OSTI) (10)

8523-2 Central Technical Files 



$$
\text { - }
$$

